Letnik XXXI, številka 5-6, 2020

Revija za teorijo in raziskave vzgoje in izobraževanja

Šolsko polje

Teaching Feminism

Editor: Valerija Vendramin

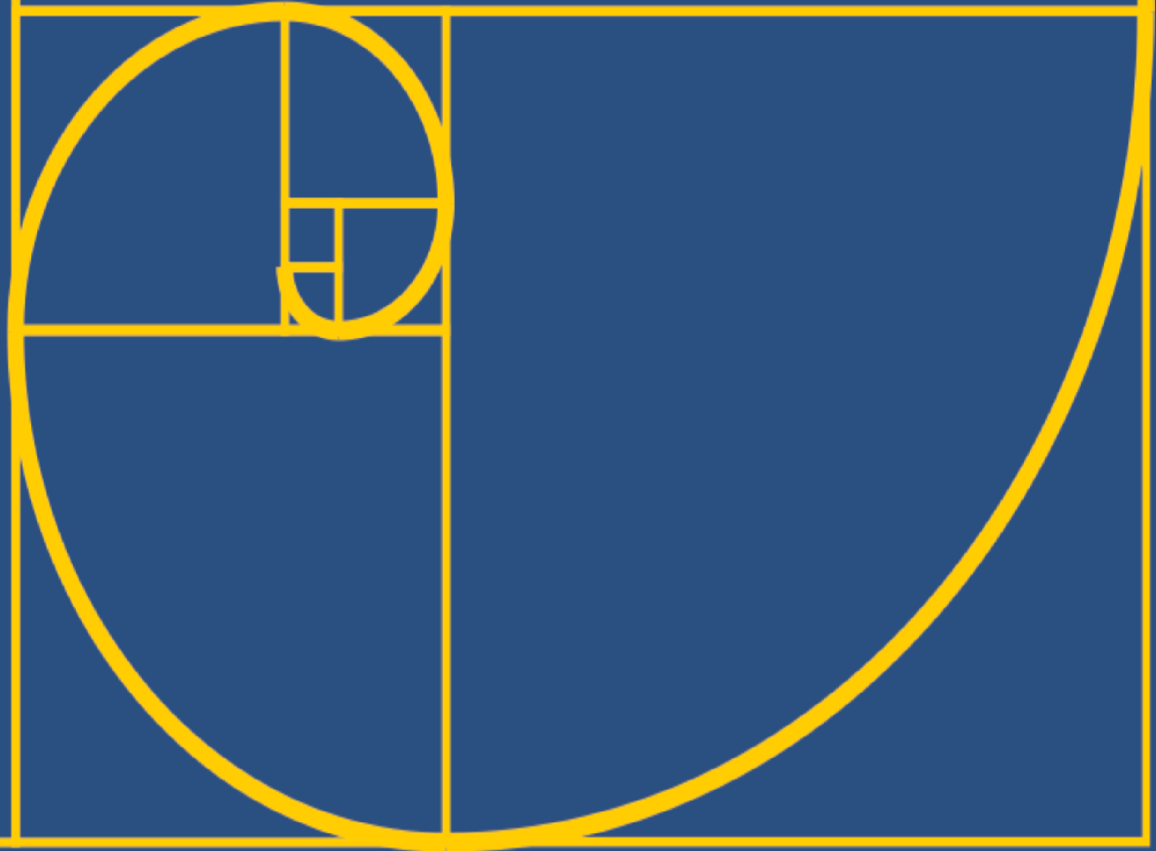




\section{Šolsko polje}

Revija za teorijo in raziskave vzgoje in izobraževanja

Letnik XXXI, številka 5-6, 2020

Šlsko polje je mednarodna revija za teorijo ter raziskave vzgoje in izobraževanja z mednarodnim uredniškim odborom. Objavlja znanstvene in strokovne članke s širšega področja vzgoje in izobraževanja ter edukacijskih raziskav (filozofija vzgoje, sociologija izobraževanja, uporabna epistemologija, razvojna psihologija, pedagogika, andragogika, pedagoška metodologija itd.), pregledne članke z omenjenih področij ter recenzije tako domačih kot tujih monografij s področja vzgoje in izobraževanja. Revija izhaja trikrat letno. Izdaja jo Slovensko druśtvo raziskovalcev solskega polja. Poglavitni namen revije je prispevati $\mathrm{k}$ razvoju edukacijskih ved in interdisciplinarnemu pristopu $k$ teoretičnim in praktičnim vprašanjem vzgoje in izobraževanja. $V$ tem okviru revija posebno pozornost namenja razvijanju slovenske znanstvene in strokovne terminologije ter konceptov na področju vzgoje in izobraževanja ter raziskovalnim paradigmam s področja edukacijskih raziskav v okviru družboslovno-humanističnih ved.

Urednistvo: Sabina Autor, Igor Bijuklič, Rajka Bračun Sova, Eva Klemenčič, Ana Kozina, Ana Mlekuž, Mitja Sardoč, Valerija Vendramin, Janja Žmavc

Glavna in odgovorna urednica: Urška Štremfel (Pedagoški inštitut, Ljubljana)

Uredniski odbor: Michael W. Apple (University of Wisconsin, Madison, USA), Eva D. Bahovec (Filozofska fakulteta, Univerza v Ljubljani), Andreja Barle-Lakota (Urad za šolstvo, Ministrstvo za šolstvo in šport RS), Valentin Bucik (Filozofska fakulteta, Univerza v Ljubljani), Harry Brighouse (University of Wisconsin, Madison, USA), Randall Curren (University of Rochester, USA), Slavko Gaber (Pedagoška fakulteta, Univerza v Ljubljani), Milena Ivanuš-Grmek (Pedagoška fakulteta, Univerza v Mariboru), Russell Jacoby (University of California, Los Angeles), Stane Košir (Pedagoška fakulteta, Univerza v Ljubljani), Ljubica Marjanovič Umek (Filozofska fakulteta, Univerza v Ljubljani), Rastko Močnik (Filozofska fakulteta, Univerza v Ljubljani), Zoran Pavlović (Svetovalni center za otroke, mladostnike in starše, Ljubljana), Drago B. Rotar (Fakulteta za humanistične študije, Univerza na Primorskem), Harvey Siegel (University of Miami, USA), Marjan Šetinc (Slovensko društvo raziskovalcev šolskega polja, Ljubljana), Pavel Zgaga (Pedagoška fakulteta, Univerza v Ljubljani), Maja Zupančič (Filozofska fakulteta, Univerza v Ljubljani), Robi Kroflič (Filozofska fakulteta, Univerza v Ljubljani), Marie-Hélene Estéoule Exel (Universite Stendhal Grenoble III)

Lektor (slovenski jezik), tehnični urednik, oblikovanje in prelom: Jonatan Vinkler

Lektor (angleskijezik): Murray Bales

Izdajatelja: Slovensko društvo raziskovalcev šolskega polja in Pedagoški inštitut

(C) Slovensko društvo raziskovalcev šolskega polja in Pedagoški inštitut

Tisk: Grafika 3000 d.o.o., Dob

Naklada: 400 izvodov

Revija Šlsko polje je vključena v naslednje indekse in baze podatkov: Contents Pages in Education; EBSCO; Education Research Abstracts; International Bibliography of the Social Sciences (IBSS); Linguistics and Language Behavior Abstracts (LLBA); Multicultural Education Abstracts; Pais International; ProQuest Social Sciences Journal, Research into Higher Education Abstracts; Social Services Abstracts; Sociological Abstracts; Worldwide Political Science Abstracts

Šolsko polje izhaja s finančno podporo Pedagoškega inštituta in Javne agencije za raziskovalno dejavnost Republike Slovenije.

Tiskana izdaja: ISSN $158 \mathrm{I}-6036$

Spletna izdaja: ISSN I581-6044

DOI: https://www.doi.org/10.32320/1581-6044.31(5-6)

Naslov urednistva:

Šolsko polje, Mestni trg 17, 1000 Ljubljana

Tel: OI 420 I 240

E-pošta: solsko.polje@guest.arnes.si 
Letnik XXXI, številka 5-6, 2020

Revija za teorijo in raziskave vzgoje in izobraževanja

Šolsko polje

\section{Teaching Feminism}

Editor: Valerija Vendramin

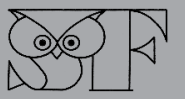





\section{Contents}

\section{Valerija Vendramin}

5 Teaching and Trending Feminism in the $2 \mathrm{I}^{\text {st }}$ Century

Editorial

Nina Perger, Metka Mencin and Veronika Tašner

I3 Teaching Feminism:Between Marginalisation and Feminist Persistence

Biljana Kašić

3I Feminism as Epistemic Disobedience and Transformative Knowledge:

Exploration of an Alternative Educational Centre

Renata Šribar

49 Study in the Virtual Class: Doings of Feminist Pedagogy

and the Covid-19 Crisis

Ana Mladenović

67 Feminist Classrooms in Practice

Mirjana Adamović

83 What Can We Learn About Feminism from Web Portals?

- Analysing Media Bulletins

Mojca Šorli

I03 Feminism and Gender-Neutral Language: Between Systems and Effects

Majda Hrženjak

I2I Sporty Boys and Fashion Girls: Manoeuvring Between Dominant Norms of Gender Identity

Valerija Vendramin

139 The Grammar of Knowledge: A Look at Feminism and Feminist Epistemologies 
ŠOLSKO POLJE, LETNIK XXXI, ŠTEVILKA 5-6

147 Reviews

157 Abstracts - Povzetki

I69 Contributors - Avtorice 


\section{Teaching and Trending Feminism in the $2 \mathrm{I}^{\text {st }}$ Century}

Valerija Vendramin, Educational Research Institute, Ljubljana, Slovenia

I $s$ feminism a new trend in popular culture? If so, is this a good or a bad thing? And, besides, what kind of feminism does this entail? Thus, to start, it is appropriate to identify some of the most prominent moments that have helped define "feminism" (understanding the term very generally here, hence the use of the quotation marks) as we know it today, to start exploring and exposing both the feminist and post-feminist characteristics, to think about the renegotiation between the two, and reflect on their influence on children and young adults. It is clear that quite specific images of womanhood/girlhood are being marketed through the media and that they are causing the repackaging of not only girlhood or womanhood but also of feminism itself (see e.g. Becker et al., 2016).

However, my aim is not to offer of a typology of contemporary "subforms" or "reformed" kinds of "feminism": there are many of them and elaborating on them would be a somewhat tedious job or, at least, a complicated issue (so I will refrain from doing it) (see also Rottenberg, 2018, p. I 66 ff). Let me just name a few of them: "choice feminism”, "power feminism", "celebrity feminism", "hashtag feminism", "marketplace feminism" and others, even "lifestyle feminism", "feminism lite" or "gateway feminism". No, one of my objectives is to point out that there is something awry with the dominant, media-regulated forms of "feminism", which

I This repackaging also "encourages girls to exchange political power for purchasing power" (Becker et al., 2016, p. 1218).

2 But wait, there is more, such as "tough cookie feminism" (which is Camille Paglia's formulation, quoted in Moi, 2006, p. 1737). Still, all this is not to be confused with different contemporary strands of feminist theorizing such as e.g. feminist materialism, corporeal feminism, post-human feminism ... (see also Lykke, 20IO, p. 13I). 
pass as the core of feminism down to generations of girls and young women. I am somewhat inclined to think that on closer inspection these forms of "feminism" are not really feminist and might, as stated by Toril Moi (2006, p. 1739), ${ }^{3}$ even further the conservative feminist-bashing agenda. However, this approach (containing my afore-mentioned doubts), according to Catharine Rottenberg, can also be problematic. For instance, it assumes that feminism has a stable essence or universal foundation (admittedly, that is not necessarily always so) ${ }^{4}$ and, as demonstrated several times in the history of feminism, "any attempt to define feminism once and for all or to police its borders, results in violent exclusions while often buttressing imperialist and racist projects" (Rottenberg, 2018, p. 169). This was clearly elaborated in Chandra Mohanty's work on the construction of non-Western women as "an ahistorical, monolithic, and coherent group or category” (Rottenberg, 2018, p. 170).

Hence, according to Catharine Rottenberg, simply "dismissing neoliberal feminism as 'faux feminism' reproduces a similar logic of exclusion”:

And while it is clear that this kind of dismissal stems from a political desire to reclaim feminism for more progressive purposes, theoretically it seems misguided. Indeed, if, on the one hand, we have witnessed the increasing entanglement of feminism with a range of neoliberal and neoconservative and even right-wing issues across the globe, on the other hand, this imbrication of feminism with non-emancipatory projects is a powerful reminder that feminism has always been an unstable signifier (Rottenberg, 2018, p. 170).

But still, one of the most important things to have in mind is: "the current shift to 'feminism is wonderful', in the mainstream media /.../ de-politicizes feminism, making it less of a radical movement that seeks social change and more a portrayal of individual empowerment on the part of exceptional women. In essence, it seeks to separate the personal from the political" (Caddell, 2015, p. ii). After years of general aversion to feminism (either its endeavours or the term itself, or both), this shift should of course be welcomed if it were not for its "rebranding" (and I apologise for this marketing expression) which "relies on disavowing the stereotype of the unattractive and sexless feminist" and/or on positioning "outside the stuffy and dry feminism associated with academia" (Rivers, 2017, p. 66). In this way, feminism has been co-opted and depoliticised

3 Let me point out that the article by Moi was issued in 2006 when feminism was indeed still the unspeakable F-word. Today (ab)uses of the word are far more common, albeit it remains to be seen to what extent the general cultural image of feminism has changed. 
and should no doubt be reclaimed as a transformative politics (Rivers, 2017). ${ }^{5}$ I could not agree more.

It might be too simplistic to suggest the interest in feminism can be attributed to the media-friendly image of "feminism" only. Yet, it is certainly true that the renewed popularity of feminism(s) has both influenced and been influenced by the commercialisation of the movement, as pointed out by Nicola Rivers (2017, p. 57). Feminism sells, or at least those strands of feminism uncomplicatedly promoting the neoliberal principles of agency, choice, and empowerment (ibid.). There is quite a noticeable shift towards the personal battles and independence of women; collective endeavours are swept aside and the principle of individualising social problems and obstacles (along the lines of "If you cannot, it is entirely your fault") is put at the forefront (e.g. Vendramin, 2018, p. 77). The images of these independent and successful women are often taken for more than what they are. Structural limitations are made invisible and success is presented as individual attainment (one hardly has to mention that the possibility of success is clearly an option for already privileged middle-class women; for the disenfranchised, less so). The collective nature of oppression is nowhere to be seen, hence there is no need for organised action to remedy social injustice (Genz, 2006, p. 343). ${ }^{6}$ This narrative has re-introduced the syndrome of "the exceptional woman", which was a recognised topos before the women's movement introduced more egalitarian principles of inter-connection, solidarity and teamwork (Braidotti, 2005, p. 4).

It might thus be overlooked that this "feminism" rather appears a lot like celebrating or show-casing traditional forms of femininity. As Angela McRobbie points out, under the celebrations of women's freedom, there is an insurgent tidal wave of patriarchalism, embedded within various forms of feminine popular culture (McRobbie, 2008, p. 539). Put slightly differently, feminist themes have been popularised and "mainstreamed", but not only that, "they have also become increasingly compatible with neoliberal and neoconservative political and economic agendas" (Rottenberg, 2018, p. II). Catharine Rottenberg uses the term "neoliberal feminism" and claims it is "a key contemporary discourse that is overshadowing other forms of feminism" (ibid., p. 2I). This makes the vocabulary of social justice quite difficult to pursue (ibid.), "as this new and increasingly popular

\footnotetext{
5 On the other hand it is true, as Janell Hobson puts it, one should not be confined to accept complicated academic prose as the only legitimate discourse, critical issues should (also) be articulated for a wider audience and messages existing in music, films, and art have the potential "to complement, not replace, the feminist manifestoes, academic monographs, policy briefs, and grassroots missions /.../" (Hobson, 2017, p. 1000). 
form of feminism has been curiously and unsettlingly unmoored from those key terms of equality, justice, and emancipation that have informed women's movements and feminism since their inception" (ibid., p. II).

Having said this, it is all the more important to strive for a historically nuanced image of feminism and women's fight for their rights. We need to be reminded once again that there are connections between gender-based oppression and the practices of searching for knowledge. This means that "the legitimation of knowledge claims is intimately tied to the networks of domination and exclusion" (Lennon \& Whitford, I994, p. I). Further (I return to this at the end of this issue of The School Field or, in Slovenian, Šolsko polje): “This recognition has moved issues of epistemology from the world of somewhat esoteric philosophy to the centre-stage of contemporary culture" (ibid.).

Here education, more precisely school curricula ${ }^{7}$ (and, ideally, school practice), has an important role as curricula define the representations and definitions of feminism and the struggles for women's rights, which may then serve as a starting point for reflecting on everyday practices in schools and acting accordingly if they are found wanting from the equality perspective. ${ }^{8}$ I am writing this with Slovenian primary school curricula in mind as I am familiar with their gaps and omissions," which somehow replicate more and more with every new edition or renewal, but the point is of course more widely applicable as also demonstrated by several authors here.

But speaking about feminism and education entails two slightly different things, which should be explained here, at least in short, as more explanations and theoretisations are available later on in this issue of The School Field. First (this is not a value-laden order), there is education about feminism - and I have already mentioned the tendency to avoid the term, referring to primary school curricula mainly (see note 9), although the authors contributing here deal with it on the university (and alternative!) level as well. Second, there is education (for) feminism or teaching from

7 It might be worth repeating that the knowledge that makes it into the curriculum is the result of complex power relations, struggles and compromises among various social groups (Apple, 1992, p. 70).

This is first of all a policy issue, which should be - with documents, recommendations and the like - a "safety net" against the exclusions, silences and taken-for-granted ideas. Another document is a curriculum with precisely defined contents and emancipatory knowledge brought to the forefront, together with the provision of tools for analysis (Vendramin, 2014, p. 902). such as sex/gender or emancipation, the term "feminism" is not mentioned at all (for a little more on this, see Vendramin, 2019). 
a feminist standpoint (i.e. as a feminist). ${ }^{10}$ Ideally, the two are joined in a struggle towards social and personal transformation or, in a slightly different perspective, " what is needed is the convergence of theory and practice (Pravadelli in Perger et al., this issue).

Nina Perger, Metka Mencin and Veronika Tašner in their contribution Teaching Feminism: Between Marginalisation and Feminist Persistence deal with feminist principles, content and practices in higher education in times of neoliberal ideology, post-feminism and the intensification of extreme-right wing politics. They look into the state of feminist topics in the context of Slovenian higher education via document analysis of the curricula of Slovenian universities. Their research shows that gender-related topics are marginalised and non-obligatory, and feminist topics sporadic.

Biljana Kašić in her contribution Feminism as Epistemic Disobedience and Transformative Knowledge: Exploration of an Alternative Educational Centre argues that an alternative form of education (i.e. outside of academic institutions) can ensure a freeing up from hegemonic and misogynist knowledge; thus, it creates a powerful shift towards feminism as an epistemic disobedience and activist theory. She further elaborates on the need to add new contents and to embed a gender perspective across the curriculum.

Renata Sribar deals with current pandemic crisis and relates it to feminist practice (i.e. pandemic-related feminist pedagogy) in her Study in a Virtual Class: Doings of Feminist Pedagogy and the Covid-ro Crisis. Her article concerns personal experiences of teaching in a virtual class and reflects on the characteristics of feminist and critical pedagogy. She presents a conceptual reorganisation via the triangulation of students, the "object", (subject matter, related experience, and embodiment through feelings), and the teacher.

Ana Mladenović also looks at feminist classrooms in her contribution Feminist Classrooms in Practice and highlights the importance of integrating feminist pedagogy throughout the entire education system. She presents examples of feminist classrooms on different education levels (preschool education, primary and secondary education). Not all of the practices are presented in the literature review; practices on primary and secondary levels are presented as reported in a semi-structured interview with a teacher in training.

Io This is not entirely the same as a standpoint as an epistemological concept, see e.g. Anderson, 2020 .

II I include not only theory in a narrower sense of the word, but also instruction from a historical perspective on the fights for women's rights etc. 
Mirjana Adamović in her contribution What Can We Learn About Feminism from Web Portals? - Analysing Media Bulletins examines the "feminist" contents of the most visited Croatian web portals and analyses feminist activities, their connotations and hierarchal power relationships. Through analysis, she identifies five thematic frameworks: feminist pioneers, female politicians and feminism, celebrity feminism, feminist activism, and feminism and film. It is shown that young people cannot really obtain a realistic picture of feminism through web portals, and rarely, in a few occasional news items, can they obtain a quick education on feminist values, and that there is much decoupling of feminist values from feminism.

Mojca Šrli in her article Feminism and Gender-Neutral Language: Between Systems and Effects presents and reflects on gender-sensitive use of language through debates conducted in the last few years in Slovenia on the Slovenian language. ${ }^{\mathrm{I2}}$ As shown, this use exceeds inclusivity in language; it must be supplemented with the awareness that choosing the masculine gender is not only a matter of grammatical rules, but androcentricity as a norm in society as a whole. Since language, as she puts it, is a key factor in the actualisation or deceleration of social equalities, what kind of messages are being sent to children, young adults?

Majda Hrženjak bases her contribution Sporty Boys and Fashion Girls: Manoeuvring Between Dominant Norms of Gender Identity on Lévi-Straussian formula "girls $:$ boys $=$ fashion : football". The article analyses how teenagers deploy clothing practices and other techniques of body self-regulation to help them deal with social control and peer pressure. The main reflection relates to the processes of self-construction of masculine and feminine identity. In the end, she turns to the role of school in avoiding reinforcement of traditional gender dichotomy and supporting expressions of alternative ways of doing femininity and masculinity.

Finally, $I$ as the editor in the article The Grammar of Knowledge: $A$ Look at Feminism and Feminist Epistemologies turn to what might be another main theme of this issue of The School Field - i.e. feminist epistemology. Here, I start with Marianne Janack's definition about the importance of "gender as an analytic category in discussions, criticisms, and reconstructions of epistemic practices, norms, and ideals" (Janack, n.d.). I emphasise the role, importance and uniting agent of feminist

My note for those not familiar with specifics of the Slovenian language (in short): unlike in English, in Slovenian, gender is not only visible in pronouns and nouns, but there needs to be gender-based agreement with adjectives and verbs as well. This feature often serves as an argument against the possibility of more gender-fair language. 
epistemology (which, of course, goes not only for this issue, but for feminism and knowledge-production generally).

This special issue ends with two book reviews. First, Sabina Autor reviews Mary Beard's book Women and Power. The second review is by Nina Perger - she looks at Sara Ahmed's book What's the Use? On the Uses of Use.

I hope that this issue of The School Field will be read and discussed, perhaps used in research and teaching. It may help open up even more new intellectual spaces of cooperation and reflection. And, of course, with any luck there will be several more to follow on similar topics.

\section{Literature}

Anderson, E. (2020). Feminist Epistemology and Philosophy of Science.

In E. N. Zalta (Ed.), The Stanford Encyclopedia of Philosophy. Retrieved

September 23, 2020, from https://plato.stanford.edu/archives/spr2020/ entries/feminism-epistemology/.

Apple, M. W. (1992). Between Moral Regulation and Democracy: The Cultural Contradiction of the Text. The School Field, 3(I-2), 49-76.

Becker, S., Thomas, D., \& Cope, M. R. (2016). Post-Feminism for Children: Feminism "Repackaged" in the Bratz Films. Media, Culture \& Society, $38(8)$, I2I8-I235.

Braidotti, R. (2005). A Critical Cartography of Feminist Post-

Postmodernism. Australian Feminist Studies, 20(47), 169-180.

Cadell, A. (2015). From Center to Margin: Feminism in an Era Mainstream Co-optation. Retrieved June 9, 2020, from http://acumen.lib.ua.edu/ content/uoors/0000001/0002158/u0015_0000001_0002158.pdf.

Genz, S. (2006). Third Way/ve. The Politics of Postfeminism. Feminist Theory, 7(3), 333-353.

Grosz, E. (2010). The Untimeliness of Feminist Theory. NORA - Nordic Journal of Feminist and Gender Research, I8(I), 48-5I.

Janack, M. (n.d.). Feminist Epistemology. The Internet Encyclopedia of Philosophy. Retrieved September 25, 2020, from http://www.iep.utm. edu/fem-epis/.

Lennon, K., \& Whitford, M. (1994). Introduction. In K. Lennon \& M. Whitford (Eds.), Knowing the Difference. Feminist Perspectives in Epistemology (pp. I-I4). Routledge.

Lykke, N. (2010). The Timeliness of Post-Constructionism. NORA-Nordic Journal of Feminist and Gender Research, I8(2), 131-136.

McRobbie, A. (2008). Young Women and Consumer Culture. An Intervention. Cultural Studies, 22(5), 531-550. 
Moi, T. (2006). "I am not a feminist, but ...": How feminism became the F-word. PMLA, I2I(5), 1735-174I. Retrieved September 20, 20202, from http://www.torilmoi.com/wp-content/uploads/2009/09/Moi_ PMLA_2006.pdf.

Rivers, N. (2017). Postfeminism(s) and the Arrival of the Fourth Wave. Turning Tides. Palgrave Macmillan.

Rottenberg, C. (2018). The Rise of Neoliberal Feminism. Oxford University Press.

Vendramin, V. (2019). “Tako je videti feminist_ka”: medijske reprezentacije feminizma in feminizem v učnih načrtih. In I. Ž. Žagar \& A. Mlekuž (Eds.), Raziskovanje v vzgoji in izobraževanju (pp. I 49-156). Pedagoški inštitut, https://www.pei.si/ISBN/978-96I-270-3II-0.pdf.

Vendramin, V. (2018). Celebrities, Consumerism, Empowerment \#FeminismForChildren. Šolsko polje, 29(3/4), 77-86. https://www.pei. si/ISSN/I58I_6044/3-4-2018/I58I_6044_3-4-2018.pdf.

Vendramin, V. (2OI4). Curriculum as a "Safety Net"?: Some Interventions into Representations of Gender(s). In F. Uslu (Ed.), International Conference on Social Sciences and Humanities: Abstracts \& Proceedings (pp. 898-903). International Organization Center of Academic Research. 


\title{
Teaching Feminism: \\ Between Marginalisation and Feminist Persistence
}

\author{
Nina Perger, Faculty of Social Sciences, Ljubljana, Slovenia \\ Metka Mencin, Faculty of Social Sciences, Ljubljana, Slovenia \\ Veronika Tašner, Faculty of Education, Ljubljana, Slovenia
}

\section{Introduction}

Cminism ${ }^{1}$ in the academy (researching, teaching, publishing) has $\checkmark$ a relatively short history. The first institutionalised women's stud1 ies course was held in the late 1950s in Australia: Dawson's course Women in a Changing World (Becchio, 2020). In the late 1960 s and early I970s, courses which placed women's lives and experiences at the centre of researching and teaching (i.e. women's studies) were introduced in the academic institutions in the United States of America, originally more as "an ensemble of courses listed on bulletin boards and often taught for free by faculty and community leaders", and later as an organised entity (Wiegman, 2002, p. I8): the first accredited women's studies course in the USA was established in 1969 , with the number of courses in universities rising steeply over the next couple of years. In the early i970s, soon after the institutionalisation of women's studies in the USA, the first extramural courses ${ }^{2}$ were developed in Britain (see Bird, 2003, p. 265), ${ }^{3}$ and in 1974 courses called "Women in Society" were introduced in the sociology department (Bird, 2003). In France, where feminist publicist activity was extremely fruitful, the first institutionalised women's studies course also

I In this article, the term women's signifies the field of study while feminist represents the approach to the field.

2 Courses, connected with the "normal" courses/programmes of a college or university, but outside it (Bird, 2003).

3 According to Humm, the first women's studies course in Britain was Juliet Mitchell's short course entitled "The Role of Women in Society" at the "Anti University" (Humm \& Bird, 2003, pp. 265, 284). 
began in the early 1970s (Ezekiel, 1992, p. 8I). In Italy, "Women's Issues" have been taught since the mid-1970s (Pravadelli, 2010, p. 63). Since the 1980s and 1990s, the number of university programmes and courses has steadily increased all over the world.

Before the institutionalisation of feminist knowledge about sexism, women's oppression, political theory and political mobilisation against patriarchy was created and circulated in feminist groups (e.g. Ezekiel, 1992; hooks, 2000). In fact, all over the world, early women's studies were closely tied with feminist movements, springing up at almost at the same time in a similar political climate. In the USA, women's studies, i.e. "the studies by, about and belonging to women" (Boxer, 2001, p. 13), were founded in left-wing political activism (the Civil Rights Movement, the women's liberation movement, the gay and lesbian movement, the movement against the Vietnam War) and the counterculture of the time. The first women's studies courses in Britain were linked to the British Women's Liberation Movement (Bird, 2003); in France, informal women's study groups came out "in the aftermath of the events in May 1968" (Ezekiel, 1992, p. 76). It could be said that women's studies themselves arose as a worldwide movement of feminist writers, journalists, scholars, groups of politically engaged women creating and transmitting feminist ideas through publications, protests and speak-outs (e.g. Ezekiel, 1992): "In the heyday of 'the personal is the political', feminists working in academia were also active in feminist groups and engaged in the battles for women's rights. The convergence between theory and practice can also be tested at another level: feminist academics worked alongside non-academics in different social contexts and cultural practices" (Pravadelli, 2010, p. 62). The circumstances of their birth were reflected in distinct features of the early women's studies programmes: the equal focus on curriculum and political activity in close cooperation with women's organisations (Buhle, 2000), i.e. "the alliance between theory and practice, institutional and non-institutional contexts" (Pravadelli, 2010, p. 63). As Pravadelli (ibid.) points out, feminists believed that feminist thought could develop only by "moving in and out of academia".

The institutionalisation of women's studies undoubtedly helped spread feminist knowledge, encouraged critical thinking and challenged patriarchal norms; it also provided a space for sophisticated feminist thinking and the careers of many feminists. Yet, from the very beginning the institutionalisation of women's studies also evoked suspicion as well as numerous questions and dilemmas on the feminist and anti-feminist side. In this article, we are interested in the state of feminist teaching and related practices in Slovenian higher education: how are feminist approaches 
integrated at the level of curriculum throughout higher education and how are these feminist practices perceived at the level of "intra-institutional" everyday life, that is, how do they cope with and within the institutions of higher education that are marked and burdened by gendered power relations. To answer this, a brief sketch of the social conditions that shape feminist practices and movements is needed.

\section{Teaching Feminism: A Brief Introduction to Uneasiness, Dilemmas, Obstacles}

Feminists often criticise academic feminism as if it has lost sight of actual human relations; that theory is no longer tied to the feminist movement and that it "even undermines the feminist movement via depoliticization" (hooks, 2000, p. 22). bell hooks, for example, claims that by the late $1980 \mathrm{~s}$ in the feminist thinking:

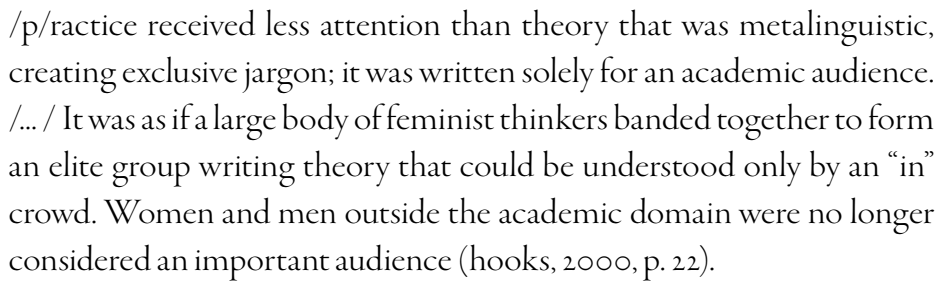

In short, academic feminism is often seen as a betrayal of the feminist movement.

However, differences, discrepancies, divergences and splits exist not simply between institutionalised feminism and feminist movements, but also within academic feminism and within feminist movements. They concern conceptualisations of sex, gender and gender identity and its constitution; understanding of the subject, i.e. a woman; understanding the relationship between equality and differences, inequality and sameness, between different axes of subordination (e.g. class/race/ethnicity/sexual orientation/gender); epistemology and research methods; strategies and tactics to realise gender equity. These differences/discrepancies/divergences/splits are also reflected in the field's naming: sociology of gender, anthropology of gender, psychology of gender; women's studies, gender studies, feminist theory. Changing the field's name to Gender Studies, for example, reflects "the expansion of the field's objects of study," but also represents "a loss of its founding feminist ideals" (Wiegman, 2016, p. 86). Namely, Gender Studies, as Wiegman points out, is often considered (even in academic discussions) as “an alternative to Women's Studies, undermining the primacy of women as the field's proper object of study" (Wiegman, 
2002, p. 19). ${ }^{4}$ Yet, although they evoke uneasiness, all of these differences/discrepancies/divergences/splits and conflicts prove the field's virility - as long as the field keeps the basic feature and goals of feminist epistemology and the feminist movement, e.g. challenging the assumptions of neutrality of knowledge and scientific objectivity (i.e. the assumption of knowledge unmarked by power relations, and demands for gender equity). This is exactly what is threatened by the changing power relations in the Academy in neoliberal times, when the governing neoliberal ideology is making deals with (extreme) right-wing political movements.

Teaching and learning about feminism can be difficult for all of these reasons. First, feminist theory claims, as Stopford (2020) notes, often challenge familiar norms, the very foundations of students' understanding of themselves, and the world around them. Namely, as Stopford analyses, feminist theory operates with critical norms that destabilise not only common-sense knowledge, but also the norms that govern the descriptive theory claims that are much more familiar to students - for many students, the clash between critical norms on one hand and common-sense "facts" and descriptive norms on the other is inevitable, not to mention the effects of this clash such as scepticism and different forms of resistance (see our discussion).

Neoliberal ideology (including neoliberal feminism), policies, common-sense representations and descriptions of the world and the identifications they impose are a constant source of these types of clashes. Neoliberal ideology interprets individual women as those who can do it by themselves, as autonomous individuals; it compels them to focus on themselves and their own aspirations. By interpreting women as those who can do everything (in the brave new world where we can all win), it is seemingly speaking from a feminist position. This (neo)liberal interpretation is fully problematic because it ignores the cultural, economic and political obstacles to do or to achieve everything. Unfortunately, some feminist movements and politics are much closer to this view than they might be willing to admit. Gender mainstreaming policies, for example, create the impression that nation states and supranational institutions have assumed responsibility for realising gender equity: the EU, for example, encourages national legislatives to take gender perspective into account, although the criteria of effectiveness - gender balance statistics - are highly

4 One of the most pressing tensions is present between so called trans-exclusionary feminism and (trans) feminism: the first attempts to draw the boundaries of who counts as women and as a minority oppressed on the grounds of gender, and thus repeats already-known struggles, stemming from the lack of an intersectional approach towards feminist issues (e.g. race, class, sexual identity ...) (Ahmed, 2016a; see also Bettcher, 20I7). 
problematic. Namely, gender balance statistics cover numerable inequities, such as conditions to get and keep a job, gaps between the poor and the rich etc. Further, gender mainstreaming politics primarily reinforce the positions and opportunities of middle-class women to enter the spheres of power and occupy hierarchical positions formerly held by men. It appears as though the EU's aims are principally focused on a set of narrow economic goals - gender equity seems more a means than a goal in itself.' This suspicion is further strengthened when we consider the EU's neutral stance on women's reproductive rights and abortion. All of these factors form the impression that feminist politics and, consequently (if feminist teaching is considered a practice that fosters feminist politics/movement), feminist teaching and learning about feminism are superfluous: as if they were needless and irrelevant because feminist aims have been realised or even exceeded, or - if they are not yet achieved - the nation state and supranational institutions will provide them.

The dark side of this neoliberal image of the new brave world where people are equal or can be equal if only they wish and work hard enough is the ascent of extreme right-wing political movements and parties. Their nationalistic ideology and stance on the biological reproduction of the nation is closely linked to gender, sex dichotomies and hierarchies. They overtly oppose gender equality referring to biology and naturalness of gender constitution, gender differences, patriarchy and heterosexuality, while strengthening common-sense beliefs in the naturalness of the social order based on gender inequality. Meanwhile, optimistic and well-intentioned neoliberals act as if they do not care about it or do not even notice it.

All of these difficulties that affect power relations in the academy and evoke resistance against feminist knowledge occur in Slovenia as well and we discuss them in the following two sections.

\section{Gender and/in Higher Education (HE) in Slovenia}

Courses and programmes based on feminist social epistemology (gender sociology, gender anthropology, women's studies, gender studies (WGS), gay and lesbian studies, feminist theory etc.) were introduced at Slovenian universities in the early 1990s, somewhat later than in Anglo-Saxon and the Nordic countries. Nevertheless, Slovenia was the first of the former Yugoslav republics to make WGS part of its institutionalised university studies. They were officially introduced in the form of a programme and/or a course in the mentioned period but, even before that, individual female professors - mainly from the social sciences and humanities - gave lectures on feminist issues (Antić Gaber, 2017). Those courses and programmes 
emerged from the women's movement and challenged traditional notions of knowledge and knowing. Early feminist critiques of the academic field "focused specially on the dominance of 'male' experience and the systemic exclusion of women as both subjects and objects of knowledge" (Kohli \& Burbules, 2013, p. 4). Yet in Slovenia an important parallel structural change was in course: $\mathrm{I}$ ) in the process of the disintegration of Yugoslavia, Slovenia had decided on independence; 2) it changed its political system from a socialist-self-management one to a liberal democracy and 3) decided on a market economy. It must be stressed that women, as Gaber puts it, "in time following independence, shared the common belief that with democracy, with political pluralism, with the competition of ideologies and political parties, the time had arrived to understand the struggle for new rights" (Gaber, 2015, p. 27). We witnessed important shifts and changes in our society, our social space was filled with "numerous opportunities, while on the other hand, brought an equal number of traps" (ibid.).

All of these shifts led to important changes in the positioning of women in society generally and in academia too. Women's initiatives were influential enough to push through entities such as Parlamentarna komisija za žensko politiko (Parliamentary Commission for Women's Policy, 1991) and Urad za žensko politiko (Office for Women's Policy, 1992) and to implement new laws and policies. The White Paper on Education (Bela knjiga o vzgoji in izobraževanju) (Krek, 1995) highlighted gender equality as one of the main objectives of education; the amount of gender-related research (gender inequalities, gender stereotypes) has increased. When we consider higher education and gender equality today, we must mention two documents that frame gender equality issues in higher education and research: The Higher Education Act (ZVis), which covers organisational and financial aspects of higher education in Slovenia, and the Resolution on the National Programme for Higher Education (2011-2020) (NPVŠII-20). The latter is a strategic document that defines the development of higher education and emphasises the quality, excellence, diversity, accessibility, internationalisation and funding of higher education as key objectives. Yet, it does not explicitly address gender issues, and objectives and measures relating to gender equality are not specified. It is right to say that this is document which is coming to an end and has yet to find a successor.

While one can assert that some progress has been made in the last decades, we can agree with Antić Gaber (2017, p. 12) that "overall, no fundamental changes have taken place". Gender question is still largely off the radar for policymakers and even more worrying for academia leadership in the country. 


\section{Gender in HE Curricula}

For many years, experts (Acker, 1994; Arnot \& Weiner, 1987; Sadker \& Sadker, 1994; Weiner, 1995) have stressed that effective gender equality in school and in society at large, as well as a diminishing of gender stereotypes, can only be achieved if we thoroughly (and on all levels) address gender issues and gender equality in school curricula. To determine the coverage of gender content in the curricula of the faculties of education, we analysed the curriculum of selected study programmes. ${ }^{6}$ There are three public faculties of education in Slovenia (in Maribor, Ljubljana and Koper). For the purpose of this paper, we focus only on faculties of education, but these are not the only educational institutions that train future teachers. In reviewing selected content in the curricula of the listed faculties, we looked for those programmes and subjects that address the issues of gender, femininity, masculinity and feminism or gender equality. We therefore searched for keywords, phrases and concepts in publicly available documents that could be related to gender issues in educational institutions. To this end, we used the method of analysing publicly accessible documents such as curricula, study programmes description documents etc. $^{7}$

\section{Results of the Curriculum Analysis of Selected Faculties}

\section{Faculty of Education, University of Ljubljana}

At the Faculty of Education, University of Ljubljana, in the programmes for Classroom Teaching, Subject Teacher in science and Art Pedagogy in the Bologna $\mathrm{I}^{\text {st }}$ cycle, we were unable to find a compulsory course with

6 The results used in this paper are part of the final report of the project entitled Gender equality in the field of education (V5-1705; 2018-2020) (Tašner et al., 2020), financed by the Slovenian Research Agency (ARRS) and Ministry of Education, Science and Sport. One topics covered by the research group was the analysis of study programmes, which form future teachers in Slovenia, from the point of view of inclusion of the theme of gender equality in selected study programmes on the tertiary education level. The method used in this part of the project was document analysis.

7 Acknowledging several advantages of the method used (e.g. availability, cost-effectiveness, and lack of obtrusiveness and reactivity that is particularly important while addressing potentially sensitive topics that may lead to biased answers, i.e. presenting oneself as a person, sensitive to gender issues), we also acknowledge its limitations. One of the most pressing limitations was the lack of opportunity for identifying and further analysing potential discrepancies between formalised and officialised documents (curricula) and teaching practices. The first may not necessarily and always reflect teaching practices and/ or the course content that is actually being taught (Bowen, 2009). Nonetheless, what is officialised and formalised by the educational institution is by itself of significance as it marks the boundaries of what is and can be "collectively accredited" and verified (as worthy of its place in higher education) by the institution itself (see, for example, Bourdieu, 2018, p. II6). 
the required keywords in the title. There is one optional course, namely Education and Gender offered in all of the above-mentioned programmes (except Art Pedagogy) in the first and second Bologna cycles. We found another optional subject, Gender studies, but the professor in charge for this subject told us "they implemented [the course] years ago, but not anymore", and could not give us a specific reason for that, except that it is not really offered to students. Some of the key (gender-related) phrases and contents can be found in the compulsory general subject Sociology of Education (in all of the above-mentioned programmes), Pedagogical Psychology, Youth Literature, EPTE, Reaction to Difference and Psychology for Teachers, and Sociology of Family for the science subject teacher programme. In the second cycle, the story repeats itself. There are no compulsory subjects that systematically deal with gender, gender equality and general gender questions.

\section{Faculty of Education, University of Maribor}

The Faculty implements three first-cycle university study programmes (Music Pedagogy, Art Pedagogy, and Classroom Teaching), and several second-cycle study programmes: Classroom Teaching (I year), Art Pedagogy ( $\mathrm{I}$ year), Music Pedagogy (I year), Inclusion in Education (2 years) and Pre-school Education (2 years).

The mentioned first-cycle programmes do not have a compulsory subject addressing the content we were looking for. Gender differences are addressed in the optional subject Child in a Group of Peers. In Classroom Teaching, some gender-related content can be found in the following subjects: Ethical and Sociological Aspects of Education, Differentiation in Mathematics Lessons (Gender and Mathematics), Developmental Psychology (with an emphasis on middle childhood). In the second cycle, the story is repeated. There is no special course dedicated to gender or gender equality. Moreover, gender is also absent from the programmes Art Pedagogy, Classroom Teaching and Music Pedagogy. In the programme Inclusion in Education, one can find the optional subject Peer Interaction in Classroom, which deals with the role of gender in children's relationships with peers.

\section{Faculty of Education, University of Primorska}

At the mentioned faculty, the focus has been on the following first-cycle study programmes: the university study programme Pedagogy, the university study programme Classroom Teaching. There is no compulsory subject in the Pedagogy programme that includes the required words in its name. There are certain topics related to gender and education in 
the subjects: Sociology of Education, Learning Processes, Anatomy and Physiology in Education, Psychology of Personality, and Sociology of the Family. We were also unable to find a compulsory subject that deals with gender in the Classroom Teaching programme. However, some gender contents are covered in the following subjects: Basics of Pedagogy, Language in Society, Psychology of Personality, and Sociology of Family.

Among the $2^{\text {nd }}$-level programmes, we found a subject entirely dedicated to gender only in the Classroom Teaching programme, namely the course Dynamics of Relationships and Gender.

From the perspective of gender mainstreaming, the analysis of selected study programmes at all three faculties allows the conclusion that some content on the topic of gender and gender equality can be found in study programmes and that few optional courses exist after Bologna (Antić Gaber, 2017, p. 23). But the situation is still far from satisfactory, mostly due to the: a) optional character of the gender-related courses on offer, meaning they do not reach the majority, let alone all students; and b) gender being only one of the many topics in the specific context of an individual course. The review demonstrates that the mentioned field of knowledge remains quite marginalised.

\section{Turning the Tables}

After discussing the wider position of gender studies in higher education, we continue with practical realisations of feminist teaching and wider feminist practices within the academic field. For that, we first make an excursion with an anecdote in order to reveal the institutional settings in which feminist teaching is being implemented - or discouraged from doing so - and the relations formed between attempts to perform feminist teaching and the student population, as well as the positioning of feminist practices within the academic field in order to discuss the possibilities of feminist practices of resistance and institutional barriers, the bricks and walls that feminist practices are encountering.

In 2015, one of the faculties of the University of Ljubljana prepared a poster aimed at encouraging student enrolment. As the faculty chiefly has women students, the poster primarily addressed potential male students in order to reach a "gender balance". To achieve this, the poster displayed one male student in a group of female students who were kneeling before him, stating "blissful among women". According to the faculty's leaders, the poster was student-made. Yet, a minority of students protested against the poster and thus a "public" debate was to be held to shed light on the pressing question of what was informally labelled "the poster affair": was the poster an innocent joke (misunderstood by feminist students and 
teachers) or a sexist incident? The answer to the question was to be provided through a debate between the protesting group, the faculty's leadership and the student group that had made the poster. Answering the question is not of our main concern here as we are more interested in the conditions and settings in which the public debate was held, especially the positionality of the table around which the debate was held. In the words of S. Ahmed, we approach the table as an institution's “orientation device that keeps things in place" (Ahmed, 2006a, p. 134). It does so by providing the ways in which the seats are taken up, thus the ways in which the positions of speaking up and the potential of being (un)heard were distributed and written into the institutional space even before the debate had taken place. Put differently, in the public debate, the seats were distributed as an extension of institutional orientation (towards sexisms and feminisms). The leadership - representing institution by delegation, incorporating institutional signs that act as "calls to order" (Bourdieu, 1991, p. 123) - was placed in a frontal-lecturing way alongside the general student group, while the protesting group was placed in front of them, facing the institution, its walls, barriers and its representative actors as if in in a hearing, in defence.

It was a feminist stance, the protest against sexism - rather than masculine domination and sexism - that needed to defend itself. Thus, the question mentioned before was silently answered before any speaking took place: the poster is a joke, misunderstood as sexism by lesbians. Despite the table being round-shaped, the way the actors gathered around it - the positionality of the table and agents' orientation towards the table - revealed the sharp edges of institutional power relations. It made visible "the surface of institutional space" (Ahmed, 2006a, p. II3) alongside its hidden depth, usually covered up by lip servicing to gender equality at the level of speeches and recommendations ${ }^{8}$ that do not (necessarily) translate into concrete institutional practices (see also Murray, 2018) and as such primarily serve as "institutional success stories" (Ahmed, 2012, p. I0) that hide the "permanence in and through change" (Bourdieu, 200I, p. 9I).

The anecdote of the poster affair makes visible the following: $\mathrm{I}$ ) the "chilly climate" of the institutional setting" (David, 20I4, p. 174) in which feminist practices take roots; and 2) reservations towards feminism by the

S. Ahmed (2006b) calls such institutional speech acts that do not do what they say, name and commit to (i.e. gender equality, antiracism) nonperformatives. Not only they fail to enact what they say, these speech acts also hinder or disable the recognition of still-persisting problems (i.e. gender inequality, racism).

Despite academic field enjoying a relative autonomy, it is still significantly shaped by "external forces expressing themselves according to the specific logic effective inside this space" (Bourdieu, 2020, p. 237). 
student population, whose attitudes to gender and feminism are blurred and distorted by countless social processes of negative stereotyping and stigmatising feminisms as movements and feminists as agents (for example, see Charter, 2015; Dyer \& Hurd, 2018; Houvouras \& Carter, 2008, on students' reluctance to identify as feminists despite generally supporting gender equality). It is this double-bind institutional setting - influenced by the wider antifeminist backlash, including the construct of "gender ideology" and of "gender as an ideology" (for a detailed discussion, see Kuhar \& Patternote, 2017) that has turned feminisms into "the unspeakable F-word" (Moi, 2006, p. 1739) and at the same time seeks to make gender studies irrelevant by constructing them as supposedly ideological, political ${ }^{10}$ and subjective, ${ }^{\text {II }}$ that feminist topics, principles and practices take place. Yet, it is also this setting in which feminist principles and practices persist and resist.

Murray (2018, p. I80), while working on S. Ahmed's concept of feminist killjoys, of feminists "killing joy" by not being willing to participate in the reproduction of masculine domination (2017), distinguishes three types of "killjoy tactics" or feminist responses to being constituted as a "challenging presence" in academia: managing, challenging, and refusal/exit (Murray, 2018). The first refers to the collective work of support and solidarity among killjoys as well as self-silencing when the "institutional wall" is deemed too high or the institutional bricks too thick (Ahmed, 2014, p. 146), and is especially important when rethinking feminist practices of resistance in intersection with precarious positions: with a precarious position, there usually comes a precarious toolbox of feminist manoeuvres. The second type of response contains directly challenges to the institutional barriers and their patriarchal, unequal and sexist settings which, as Murray (ibid., p. I82) emphasises, should also be addressed alongside an agent's position within academia: "those with more security and higher up the academic ladder have a greater power to shape the academic culture". The same holds true for the third one - refusal and exit from academia due to unbearable patriarchal burdens - which, as $S$. Ahmed who herself resigned from her post at Goldsmith due to the institution's incapability to address sexual harassment claims warns, is far

IO To the reproach of science being political, we reply using Bourdieu's words: "I myself fell victim to that moralism of neutrality, of the non-involvement of the scientist/.../ As if one could talk of the social world without being involved in politics!" (Lahire, 1999, p. I5; Lane, 2006, p. I). simply erased from academia, are the removal of Gender Studies from the list of accredited Master Programmes in Hungary in 2018 (see the European Communication Research and Education Association's public statement, 2018), and the proposed ban on the teaching of gender studies in schools and universities in Romania in June 2020 (Tidey, 2020). 
from accessible to everyone within academia: "other feminists in the same situation might stay because they cannot afford to leave" (Ahmed, 2016b).

However, the first two responses as discussed by Murray (2018) can be approached as two sides of the same coin as feminist resistance to and in the educational setting and its baggage of masculine domination involves both managing the challenging as well as challenging the managing. Namely, as another similar study shows (Perger, 2016), it is important to recognise the toll that challenging and resistance takes and the strategic, ${ }^{12}$ almost instant adjustments of resistant practices to situational circumstances, such as particular power relations (i.e. challenging the faculty's dean or a colleague) in a given situation and the nature of the obviousness of the problem at stake which may make it easier or harder for a killjoy to pinpoint a problem. Thus, managing the challenging refers to shielding oneself from being constituted as a problem due to the naming and exposing of a problem (Ahmed, 2015) that happens within a "stuck place" (Lipton \& Mackinlay, 2017, p. 86), in a moment of hesitation, not only in relation to institutional agents but also in relation to the student population, where (feminist) lecturers may take into account the "spectre of bad student feedback" that is hanging over the classroom (Murray, 2018, p. 168), the threat of students' "dissatisfaction", which may discourage killjoys from (fully) challenging students' taken-for-granted attitudes to gender. It contains a situationally-adjusted feminist toolbox, ranging from raised eyebrows and a cynical smile through to direct confrontation. Despite functioning as a shielding strategy aimed at providing conditions that enable feminist resistance without risking too much, managing the challenging may at the same time constitute feelings of guilt, of constant self-surveillance, feelings of not being (vocal, resistant, persistent) enough and/or feelings of being too much (self-managed, self-disciplined and self-silenced) (see also Lipton \& Mackinlay, 2017, pp. 85-113). Thus, managing the challenging may prove to be an issue due to the "after-effects of silencing": "I should have stood up, I should have said more, I should have opened my mouth" (ibid., p. 7I). Stated differently, it may lead to a particular kind of an (activist) imposter syndrome (Murray, 2018, p. 173).

The conditions which make it practically reasonable for feminist killjoys to manage one's feminist practices of resistance in order to avoid various kinds of sanctions, that is, the conditions "making unbearable /of/ the consequences of not willing what someone wills you to will" (Ahmed, 2014 , p. 55) are those that need to be challenged. It is these conditions that

I2 We refer to the "strategic" element of one's practices in a Bourdieusian sense, meaning a practical reason, a feel for the game rather than a conscious calculation (Bourdieu, 2008, p. 159). 
predetermine and prearrange the "seating order" at a supposedly roundshaped table; they predetermine who gets to be recognised as authorised to sit at the table and speak or, more specifically, who gets to speak with authority grounded in the "symbolic profit of normality" (Bourdieu, 1996, p. 23) and with an institutional backup, provided to those whose speaking up is integrated into the institutional life-as-usual, and whose speaking up is distorted through the predominant attitudes and perceptions of feminists being "lonely and unhappy, angry, man-hating, lesbian[s]" (Dyer \& Hurd, 2018, p. 443) and who are thus left unheard. Hence, the tables need to be turned and antifeminism, masculine domination and the accompanying sexism - rather than feminist practices and principles - need to be questioned and seated on the other side of the table.

\section{Conclusion}

Feminism in the higher education of today is faced with numerous challenges. Recognising the embeddedness of higher education in the wider social environment, and thus its susceptibility to social processes and "happenings", it is important to acknowledge the dangers represented by neoliberal ideology alongside the strengthening of nationalistic ideologies and extreme right-wing movements and parties in relation to feminist practices. Namely, through the lenses of neoliberal ideology, feminism is perceived as a redundant and irrelevant part of the present, a remainder of the past, of the "old times", that was supposedly successfully addressed through and with the individual's wish to work hard enough supported by national and international frameworks of gender equality - in order to overcome (gendered and gendering) obstacles on their career paths. While these neoliberal "post-feminist" times with their easy-to-sell exceptional successful stories - seen more as the rule than the exception - constitute feminism as needless, right-wing movements alongside anti-feminist backlashes in the form of "gender ideology" perceive feminism as a threat, or better said, as an obstacle that disables and makes it harder for the past of the unquestioned patriarchy and masculine domination to return.

Due to higher education's social embeddedness, these social processes undoubtedly touch on the state and life of feminist principles and within higher education's institutions. Thus, at the level of curricula, women's studies and feminist approaches are rarely explicitly mentioned and stressed, let alone obligatory for all students. Rather, it seems like higher education in Slovenia continues to shy away from recognising the importance of feminist teaching and knowledge production. As such, gender is put on the bench when it comes to institutionalised and officialised 
curricula and forced to creep into the teaching practices: feminism - that creepy thing. It is mostly left up to the willingness of teachers to do feminism in the classrooms; conversely, their unwillingness to unquestionably accept the patriarchal ordering of higher education. Thus, feminism, its principles and practices (still) hold a marginal position in higher education. Nonetheless, feminism resists and, despite the backlashes that aim to extort a price for not being willing to support institutional walls as they exist, including their gendered power relations, it persists.

What our article has attempted to show and hopefully achieved is that rather than accommodating feminism to fit higher education, its institutional walls and accompanying silences and silencing - mostly through and by allowing its neoliberal variant to enter in the companionship of post-feminism narratives that are ill equipped to face the challenges coming from right-wing movements, that is, by the "complicities of institutionalizations" (Wiegman, 2002, p. 89), it is higher education that must be adjusted - remade and reshaped - according to feminist principles (and other social justice principles). After all, feminist knowledge is indeed, as bell hooks (2000, p. 24) emphasises, for everybody.

\section{References}

Acker, S. (1994). Gendered education: Sociological reflection on women, teaching and feminism. Open University Press.

Ahmed, S. (2006a). Queer phenomenology. Duke University Press.

Ahmed, S. (2006b). The nonperformativity of antiracism. Meridians, 7(I), 104-I26. Retrieved July 5, 2020, from http://www.jstor.org/ stable/40338719.

Ahmed, S. (2012). On being included: Racism and diversity in institutional life. Duke University Press.

Ahmed, S. (2014). Willful subjects. Duke University Press.

Ahmed, S. (2015). Introduction: Sexism - a problem with a name. new formations: a journal of culture/theory/politics, 86, 5-13. Retrieved June I5, 2020, from https://www.muse.jhu.edu/ article/604486.

Ahmed, S. (2016a). An affinity of hammers. Transgender studies quarterly, $3(\mathrm{I}-$ 2), 22-34.

Ahmed, S. (2016b). Feministkilljoys: Resignation is a feminist issue. Retrieved July 9, 2020, from https://feministkilljoys.com/2016/08/27/ resignation-is-a-feminist-issue/.

Ahmed, S. (2017). Living a feminist life. Duke University Press.

Antić Gaber, M. (2017). Mapping Women's and Gender Studies in the Academic Field in Slovenia. CEPS Journal, 7(2), 
9-27. Retrieved June 26, 2020, from http://www.dlib.

si/?URN=URN:NBN:SI:doc-9 KZK 2 OXX.

Arnot, M., \& Weiner, G. (Eds.) (1987). Gender and the politics of schooling. Hutchinson.

Becchio, G. (2020). A History of Feminist and Gender Economics. Routledge.

Bettcher, T. M. (2017). Trans feminism: recent philosophical developments. Philosophy Compass, I2(II), I-II.

Bird, E. (2003). Women's studies and the women's movement in Britain: origins and evolution, 1970-2000. Women's History Review, I2(2), 263-288.

Bourdieu, P. (1991). Language and symbolic power. Polity Press.

Bourdieu, P. (1996). On the family as a realized category. Theory, culture \& society, $13(3), 19-26$.

Bourdieu, P. (200I). Masculine domination. Stanford University Press.

Bourdieu, P. (2008). The bachelors' ball: The crisis of peasant society in Béarn. Polity Press.

Bourdieu, P. (2018). Classification struggles: General sociology, volume I, Lectures at the College de France, I98I-1982. Polity Press.

Bourdieu, P. (2020). Habitus and field: General sociology, volume 2, Lectures at the College de France, 1982-1983. Polity Press.

Bowen, G. A. (2009). Document analysis as a qualitative research method. Qualitative research journal, g(2), 27-40.

Boxer, M. J. (2001). When Women Ask the Questions: Creating Women's Studies in America. Johns Hopkins University Press.

Buhle, M. J. (2000). Introduction. In F. Howe (Ed.), The politics of women's studies: Testimony from 3 o founding mothers ( $\mathrm{pp} . \mathrm{xv}-\mathrm{xxvi})$. The Feminist Press at the City University of New York.

Charter, M. L. (2015). Feminist self-identification among social work students. Journal of social work education, $S I(\mathrm{I}), 72-89$.

David, E. M. (2014). Academic feminism today: Towards a feminized future in global academe. In E. M. David, Feminism, gender and universities: Politics, passion and pedagogies (pp. 173-191). Ashgate Publishing Limited.

Dyer, S., \& Hurd, F. (2018). Changing perceptions about feminists and (still not) claiming a feminist identity. Gender and education, 30 (4), 436-449.

European Communication Research and Education Association - ECREA (2018). Public statement on removal of gender studies programs in 
Hungary. Retrieved July I2, 2020, from https://www.ecrea.eu/ news/6883754.

European Commission (2011). Strategy for equality between women and men 20Io-20I5. Publications Office of the European Union. Retrieved July 20, 2020 , from https://op.europa.eu/en/publication-detail/-/publication/ c58de824-e42a-48ce-8d36-ar6f3oef7orb/language-en.

Ezekiel, J. (1992). Radical in theory: organized women's studies in France, the women's movement, and the state. Women's Studies Quarterly, $20(3-4), 75-84$. Retrieved June 19, 2020, from www.jstor.org/ stable/40003705.

Gaber, S. (2015). Contemporary Slovenian Society and its Rationalities. In M. Antić Gaber (Ed.), Gender Structuring of Contemporary Slovenia (pp. 23-33). Peter Lang Edition.

Higher Education Act (1994). Retrieved September 7, 2020 , from http://pisrs. si/Pis.web/ pregledPredpisa?id=ZAKOı72.

hooks, b. (2000). Feminism is for everybody: passionate politics. South End Press.

Houvouras, S., \& Carter, J. S. (2008). The F word: College students' definitions of a feminist. Sociological forum, 23(2), 234-256. Retrieved July 2, 2020, from https://www.jstor.org/stable/ 20110263.

Kholi, R. W., \& Burbules, C. N. (2013). Feminism and Educational Research. Rowan \& Littlefield Education.

Kuhar, R., \& Patternote, D. (Eds.) (2017). Anti-gender campaigns in Europe: Mobilizing against equality. Rowman \& Littlefield International Ltd.

Lane, J. F. (2006). Bourdieu's politics: Problems and possibilities. Routledge.

Lipton, B., \& Mackinlay, E. (2017). We only talk feminist here: Feminist academics, voice and agency in the neoliberal university. Palgrave Macmillan.

Moi, T. (2006). "I am not a feminist, but ...”: How feminism became the F-word. PMLA, I2I(5), 1735-I74I. Retrieved June 23, 2020, from http://www.jstor.com/stable/25501655.

Murray, Ó. M. (2018). Feel the fear and killjoy anyway: Being a challenging feminist presence in precarious academia. In Y. Taylor \& K. Lahad (Eds.), Feeling academic in the neoliberal university: Feminist flights, fights and failures (pp. 163-189). Palgrave Macmillan.

Perger, N. (2016). Sexism: naming a problem, becoming a problem. Teorija in praksa, 53(6), 1386-1400. Retrieved June 23, 2019, from http://www. dlib.si/?URN=URN:NBN:SI:DOC-JZTXWTS9. 
Pravadelli, V. (2010). Women and gender studies, Italian style. European Journal of Women's Studies, I7(I), 6I-67. Retrieved July 4, 2020, from https://hal.archives-ouvertes.fr/hal-00612825/document.

Resolution on the National Higher Education Programme $2011-2020$. Retrieved September 7, 2020, from https://zakonodaja.sio.si/wp-content/uploads/sites/ro/2011/o8/Res_National_HEP_2011_2020.pdf.

Sadker, M., \& Sadker, D. (1994). Failing at fairness: How our schools cheat girls. Touchstone.

Stopford, R. (2020). Teaching feminism: problems of critical claims and student certainty. Philosophy \& Social Criticism, 46(10), 1203-1224.

Tašner, V., Gaber, S., Antić Gaber, M., Mencin, M., Podreka, J., Žveglič Mihelič, M., Hribernik, A., \& Šušterič, N. (2020). Poročilo CRP Enakost spolov na področju izobraževanja (vsebinska priloga) [Gender equality in the field of education, unpublished report].

Tidey, A. (2020). Romania bans gender studies. Euronews. Retrieved July I2, 2020, from https://www.euronews.com/2020/06/17/romania-genderstudies-ban-students-slam-new-law-as-going-back-to-the-middle-ages.

Weiner, G. (1995). Feminism in education: An introduction. Open University Press.

Wiegman, R. (2002). Academic feminism against itself. $N W S A$ Journal, I4(2), 18-37. Retrieved June 19, 2020, from www.jstor.org/ stable/4316890.

Wiegman, R. (2016). No guarantee: Feminism's academic affect and political fantasy. Atlantis, 37(2-2), 83-95. Retrieved May 16, 2020, from https://journals.msvu.ca/index.php/atlantis /article/ view/83-95\%20 $\mathrm{PDF} / 83-95$. 



\title{
Feminism as Epistemic Disobedience and Transformative Knowledge: Exploration of an Alternative Educational Centre
}

\author{
Biljana Kašić, University of Zadar, Zadar, Croatia (retired)
}

\section{Introductory Note: Difficulties}

W

hile approaching the issue of non-institutional education in terms of feminism nowadays for this article, I must admit I felt quite uncomfortable, even anxious, for several reasons. First, the commitment made in this type of education cannot be measured at the level of type of institutional education but assumes a full socio-bodily engagement, meaning the deep embeddedness of all subjects in the entire process. Moreover, it is governed by ideals which, by critically analysing that very education, require a distinct ethico/political/theoretical stance coupled with emancipatory educational politics as the ultimate foundation. Second, given that the feminist "we", namely the status of the subject of feminism lying at the core of this type of education, now finds itself under the serious threat of many current overlapping forces, we are facing new modes of exclusions to attaining subjectivity and agency while questions of what these categories mean have become more fragile and more difficult. Finally, what is the main objective of the Centre for Women's Studies in Zagreb in continuing with alternative education if it cannot challenge the mainstream education in the full sense of that word, namely when its transformative effects have consistently been ignored, 'neutralised' or even disrupted by many factors, especially during the last few years. We are now witnessing various obstructive contextual moments (neoliberal politics, market-oriented academy, neo-conservative movement, retrograde backlash trends, among others) on both the global and local levels as well as new-old prejudices with respect to feminist epistemology, disciplines and education. 
At one moment, I felt like giving up on yet another attempt at analysing what this is all about and taking refuge in feminist scepticism, but I resisted. There is no possibility of any pulling back, not anymore.

\section{Promising Entry}

I recently reread Nora Sternfeld's article “Unglamorous Tasks: What Can Education Learn from its Political Traditions?" (Sternfeld, 2010), which fully reinvigorated my previous ideas on how alternative education might look like, emboldening me to create the grounds for exploring the role of women's studies education in the current and quite specific historical and cultural context. It also enabled me to help move in this direction, despite some inner reluctance and sites of resistance. Instead of promoting certain nationally-oriented goals, culture and values or reproduction of knowledge as embedded in the traditional tasks of education, Sternfeld opted for another intention of education. In her view, education is " /... about exploring the possibilities of an alternative production of knowledge that resists, supplements, thwarts, undercuts, or challenges traditional forms of knowledge" (Sternfeld, 20Iо, p. r).

Sternfeld elaborated her critical ideas while rethinking the traditions of political education via examples of the role of Left protagonists (Walter Benjamin, Edwin Hoernie, Bertolt Brecht) in the Germany of the Weimar Republic and their ideas on "communist pedagogy" and "teaching play" methods, then with regard to the "pedagogy of the oppressed" and "liberation pedagogy" first developed by the Brazilian theologian Paulo Freire, and further elaborated by Peter Mayo, as well as more recent radical, feminist and antiracist education (Henry A. Giroux, bell hooks) from the 1960 s onwards. By using this historical trajectory of critical ideas and practices, she wanted to explain not only which educational techniques have guided towards progressive tasks within twentieth-century (post)-modernity, but why we need a politicality of education nowadays.

My analysis somehow emerges as a productive response to some of the theses set out in this article. Three postulates from Sternfeld's text are relevant here: first, there is no neutral education while dealing with specific conditions and contingencies as well as with one's own experiential gesture; second, education is the very process of taking a stand that both dismantles the traditional educator/learner (subject-object) relationship and urges for emancipatory action; third, "there is always something unforeseeable in education" (ibid., p. 5) that sheds more light on the entire process, making it exciting, unpredictable and uncontrollable. 


\section{The Centre for Women's Studies Zagreb: Contexts, Questions, Desires}

Rather than attempting to explore the above-mentioned postulates in any well-ordered manner, I instead wish to focus on certain issues they trigger and imbue and which I see as significant for feminist alternative education. By using the Centre for Women's Studies in Zagreb/Croatia as an example, I argue that an alternative form of education outside of academic institutions can ensure a freeing up from hegemonic and misogynist knowledge more than the mainstream one, above all by creating a powerful shift towards feminism as an epistemic disobedience and activist theory. Thereby, the issue of feminism as epistemic disobedience and activist theory is not the point of departure in my analytical task, but one of the most vitalising impulses of feminist scholarship aiming for transformative knowledge.

Before moving deeper to explore its modes and effects, some facts need to be noted to analyse this specific feminist education programme. Founded 25 years ago, the Centre for Women's Studies was the first and today still is the only place offering an interdisciplinary and comprehensive programme in women's/feminist studies in Croatia. Run by feminists, namely scholars, artists, and women with experience in women's and civil activist work, the programme throughout all these years has been created and performed using its own model, content and tools. Through a wide range of ingeniously conceptualised modules/courses/workshops/actions, it offers students innovative multi- and interdisciplinary education based on critical pedagogy and continuous self-experimenting approaches and perspectives (Kašić, 2016). More precisely:

In the conceptual-epistemological sense, the contents of the educational program are at one level interdisciplinary and connected multitextually, on another level they become intertwined with experiential knowledge, while courses, modules and seminars, with few exceptions, function more as 'thematic studies', and less as studies of the disciplines viewed from a women's/gender perspective (Barada et al., 2003, p. I2I).

Over the whole time, it has been designed as an open model of education that entails an immensely inspiring programme based on the theoretical articulation of feminism and feminist experience, feminist pedagogy and experiential learning styles, personal expressiveness and art. Along with developing its own education matrix, the idea of the Centre has always been to provide its students with a motivating space for creative learning and personal "growth". In short, the Women's Studies education programme was primarily conceptualised as a critical reading of various fields of scholarly work, reality, iconography, literature, the media, visual 
signs, body, stereotypes etc. through multiple exchanges, as well as consciousness-raising studies to a certain extent.

Despite facing many changes (educational, intergenerational, from women-only to queering students, among others) and obstacles (structural, political, financial etc.), the Centre has persisted in its mission to affirm feminism as an indisputable knowledge claim. By carrying out the education at the crossroads of disciplines (humanities and social sciences, but also natural sciences), artistic practices and activism, it has attempted to see which feminist ideas circulate across them and what are the ranges of their influence and shifts. While in 1995, in the context of (post)war conflicts and dissolution of the union of Yugoslav states, the Centre took on feminist theory as a critical tool against the nationalistic ideology and the war paradigm, then acting as a kind of ethical survival, nowadays there are other questions and motives that matter.

How can we invent new feminism(s) as an emancipatory promise once more, as a radical discourse that works against inequalities, the subjugation of women, and impediments to freedom while confronting neoliberalism and "neoliberalising feminism" (Prügl, 20I5)? Since "the neoliberal trend is impregnated /.../ with old fashioned academic design that counts on (neo)conservativism" (Kašić, 2016, p. 130), retrograde paths and (neo)traditional morality, how can we then respond to the sexist, androcentric, anti-gender and racist assumptions that deepen inequality and foster social exclusion and discrimination? How can we through feminist lenses at the same time reflect upon topics that include the state of critical approaches to rights, discriminatory practices and injustice, and endeavour to create epistemological alliances with critical studies such as decolonial or antiracist research studies, among others? Also, how can we re-posit the role of feminist agency in a post-(neo)Marxist, post-(neo)colonial, and postmodern epistemological context in order to affirm the feminist struggle and transnational solidarity across the borders (Mohanty, 2003)? These are some of the urgent issues that require careful attention for analysis. Finally, which radical interventions are needed in feminist education in order to respond to these on-going demands?

\section{Feminism as Subversive Knowledge: A Troubling Setting}

/.../ feminism as an epistemological project is /... / a struggle for meaning, for concepts, for the tradition of thought. It is an oppositional, potentially (subversive) knowledge that challenges the ruling ideas, questions the literary, philosophical, historical canon, transforms "official knowledge" 
and, in short, calls into question everything that is taught at universities (Bahovec, 2002, p. 23).

Almost two decades ago, the Slovenian theorist Eva Bahovec made the above statement about feminism, which in my view is more than relevant here. This concerns the radical deconstruction of the entire tradition of thinking "inside", or what is considered to be "official" (male, heteronormative, universal) knowledge, along with creating the foundations for a new tradition at the threshold of the epistemologisation of the concepts of "absence" and (female) Other, and the (feminist) theory that it has incited.

When thinking about feminist knowledge within the educational institutional frame, the whole issue takes on a new problematic dimension. While agreeing with Mary Evans's statement that in the meantime "feminism has achieved at least partial academic recognition" (Evans, 2003, p. I5), it is still unclear to what extent this recognition assumes feminism's subversive and counter-canon potential. Namely, just the fact that, as Bahovec rightly considered, the potentially subversive knowledge that is that distinct feature the epistemic status of feminism makes specific at the same time provides for a continuous tension between feminism and its academic verification. On one hand, feminism means permanent questioning and challenging the foundations and canons of official knowledge across various disciplines, while on the other it constructs a space for its more viable basis and acknowledgement. This means both adding new contents into existing scientific disciplines and embedding a gender perspective across the curriculum as well as introducing different epistemological and analytical tools as its feminist standpoint theory, for example (Smith, 1987; Harding, 2004; Hill Collins, 2009). Starting from the premise that knowledge is always socially situated and that women's lived experiences are crucial for any scientific enquiry, this approach over the last few decades has introduced critiques of the relationship between material experience, power and epistemology that in various ways have influenced the production of knowledge.

Since neoliberal trends in conjunction with scientific backlash have in many respects shifted the university's role in the direction of a managerial and almost tedious institution (Butler \& Athanasiou, 2013; Alvanoudi, 2009), along with changing the existing disciplines, imposing new curricula, and diminishing their critical stimulus, feminist scholars are confronting new-old obstacles and hostility to feminism. The main question today is not whether the academic community is willing to fully allow a counter-hegemonic scientific narrative such as feminism into 
its cognitive and educational texture, but how and whether at all feminism itself resonates with this type of academy and marketability-oriented knowledge in particular.

Going back to Bahovec's key argument on feminism as being oppositional, namely subversive knowledge, we can see two evident tendencies in the Croatian academic framework which are quite opposite from the feminist drive. In addition to systematically excluding or reducing educational subjects with a clear feminist agenda at Croatia's universities over the last decade, on-going "disciplining" disciplines are in place. Central to the latter point, a hybrid type of bureaucratic-disciplinary surveillance has been established, by governing the scientific disciplines and their educational curriculum it insists on a "purity" of disciplines, namely the centring of scientific disciplines around their core subject and methodological axis (Kašić, 20II). Maria do Mar Pereira (2017) quite clearly noted that we should deal with the mainstream knowledge of scientificity while women's, gender, feminist studies (WGFS) "is not quite proper academic knowledge" (Pereira, 2017, p. I) One consequence of this process is concealing, misusing or giving up the interdisciplinarity that is dramatically changing educational settings (Hemmings, 2008; Liinason \& Holm, 2006).

An emerging question here then is what is the place for feminism and critical pedagogy within this educational framework? While the situation within the university is not promising for either the epistemic status of Women's/Gender Studies ${ }^{1}$ or feminism as a theoretical or activist 'project' that reflects processes in academia worldwide, alternative education seems like the only desirable place or, better, a theoretical "asylum" for experimenting, self-reflecting and subverting self-evident clichés and canons of knowledge production as well as a different entry into feminism.

In the research project on women's studies education at the Centre for Women's Studies, whose results were published in the book Privilegiranje rubova. Intervencije i prilozi feminističkoj epistemologiji / Privileging the Margins. Interventions and Contributions to Feminist Epistemology/ (Čakardić et al., 2010), students of Women's Studies frequently identify it

One of the paradoxes concerning Women's/Gender studies in the Croatian Academy is that Gender Studies is entered in the scientific categorisation of programmes recognised by the National Council for Science (in 2009 it was classified as an interdisciplinary field of science; source: "Ordinance on scientific and artistic areas, fields and branches", from 22. 09. 2009), despite the fact that neither Gender nor Women's Studies as an integral field of knowledge has become a part of the academic curricula in Croatia. It should be noted that this initiative for verifying Gender Studies as an academic field came from the Centre for Women's Studies in collaboration with the Department of Ethnology and Cultural Anthropology, Faculty of Humanities and Social Sciences in Zagreb. 
as a "safe place" ("oasis", "shelter", “comfortable women's club”) in which the notion of security is translated into a "different kind of space", also understood as an "alternative" space as well as an epistemologically new space.

Here I cite an example from an interview with one of the students:

Women's Studies epitomised a "safe", different intellectual, emotional, conceptual, cognitive space. A different way of knowing. A space in which one could "extend" in an unconventional or conventional direction without fear or disparagement. Suddenly, what I was feeling was legitimate, and not (only) that what could be gauged. /.../ It was unusually important to know, to discover that what I perceived as me could be completely epistemologically legitimate (excerpt from an interview with a Women's Studies student, generation 2006/2007).

As may be seen from the above excerpt, the space for feminist teaching means a safe place for articulating the self, which is a prerequisite for learning feminism and for the mutual exchange of ideas and thoughts. For bell hooks, the politics of location is inseparable from the politics of knowledge and the politics of resistance, and both derive their meanings from theorising about the experience of transformation and the art of creating new knowledge, which is essentially a "plan for radical critical practice" (hooks, 1996, p. 5i).

In her essay "Rethinking the Time of Feminism", Drucilla Cornell states: "Feminism is radical because it demands that we re-think the 'origins' and the 'limit' of philosophical discourse, even as we are challenged to do so philosophically" (Cornell et al., I995, p. I49).

Here, I would like to elaborate more on the potential held by disobedience while remaining in the terrain of feminist epistemology. Bearing in mind all of its above philosophical foundations, I felt somewhat uneasy with the notion of epistemology firstly due to its discursive pretension to embrace totality or wholeness in terms of knowing, marked as "universal". The inability of recognising examples of misogyny in science or humanities, or the sexism that thus institutionalises the inferiority of women in discourse through epistemic operability, refers to the historical refusal to unfold the knowledge formatted within hegemonic universal epistemology. The more I dealt with feminist epistemology, the more I found its subversive potential for creating some of my arguments around justifying feminist claims for recognition and re-appropriation of the notions and concepts which have been stolen from women. Questioning concepts such as gender/sex differences, discrimination, misogyny, cognitive biases and sexism, domination and colonisation, the relations of sexual identity 
and dominant matrices in knowledge, even though it causes anxiety and distress, and often anger and resistance, is the demand of feminist epistemology. In other words, not only is feminism epistemologically structured out of resistance, and is thus in many ways a counter-discursive position, but in resignifying the referential fields of different backgrounds and historical experiences, it directly affects the change in power relations between the sexes in the social realm and theory, questioning authorities and transforming knowledge, creating and acting on critical knowledge. This brings into question not only the status of "agency" in theory but also works to (re)articulate theoretical concepts both for the self-authorisation and radicality of theory.

\begin{abstract}
What a pleasure it was to listen to philosophy in Women's Studies! I knew there was a different way of understanding the misogyny of philosophers like Hegel and Kant as well as the absence of women in philosophy. But I was missing the "key" to exposing this epistemic blindness. And myself in the theoretical chaos. Beauvoir - Wittig - Butler, how many inspiring thoughts, connections and important arguments! I felt it free from ideas (excerpt from an interview with a student generation, 2017/2018).
\end{abstract}

Therefore, when I think of feminist epistemology, I always think of both the extension and conversion of its meaning that in a parallel way signifies critical ways of knowledge, namely decolonising the self (Lugones, 2010) in terms of being free and being a part of the mutual decolonising of knowledge. In this regard, feminism(s) function(s) as many feminist theorists from Simone de Beauvoir to Audre Lorde, from Trinh Minhha to Maria Lugones, Nadežda Čačinovič and Chizuko Ueno imagined, as a kind of disobedience itself by opening up the long-running argument of theoretical "universality", by freeing language up from homogenous or gender-neutral interpretations or dismantling the objective grounds of truth, by enabling women to create their own spaces, epistemologically new ones, by subverting male-dominated discursive codes in order to save or create meanings of their own selves.

\title{
Feminist Classroom and Critical Pedagogy
}

How can we talk about feminism? How can we teach feminism and with which methodological and pedagogical tools? These questions are always in the midst of discussions among feminist scholars since the politics of knowledge is inseparable from the "politics of location" (Rich, 1986) as a signifying practice that grounds feminist theory in accountability for the situatedness of knowledge production. 
Throughout all these years, by creating a feminist classroom, different generations of students with their feminist teachers have demonstrated an almost impossible task: bringing together a rapidly changing student body and the more inclusive knowledge of feminist scholarship. Despite all the ongoing concerns around education and obstacles the Centre for Women's Studies has faced, there is still increasing student interest in attending the Centre's informal comprehensive I-year programme. From the very beginning, the Centre's students have had an opportunity to listen to feminist scholars and first-hand "activist" experiences of women from various women's groups and organisations, as well as from artists who have cooperated with the Centre on numerous occasions. During educational learning, students are encouraged to articulate their own voice and become aware of their own affinities, while witnessing how feminism can ensure another perspective for analysing different subjects as well as a space for dialogue. Along with the desire to gain feminist knowledge and its critical engaged drive, one of the motivations today is certainly their wish to contribute to the fight against endangering women's rights, injustice, discrimination as well as neoconservative, retrograde trends of misogyny and sexism.

The majority of the Centre's students have also seen this education as an opportunity to (de)construct subjectivities or create new ones based on feminist insights. In order to clarify the construction and deconstruction of gender in terms of understanding their meanings in the modern construction of the mind/nature frame and opening up to alternative subjectivities, Evelyn Fox Keller reminds us how "this method of feminist analysis is unquestionably powerful, but it is not always unproblematic" (Keller in de Lauretis,1986, p. 67).

Two difficulties spring to mind here: one is connected with the stubborn picture that relies on designed polarities (female/male images of genders and their archetypical myths), and the second one arises from the problem of acceptance gender variations or, as translated in contemporary discourse, "queering gender". Teaching "queering gender", for example, requires a fresh methodological approach for which the Centre, instead of being pedagogically well-prepared, offers a good theoretical and cultural analysis.

However, many students emphasised how this type of education was a way of enabling their personal transformation and growth. The following accounts of female students illustrate this:

I don't have a clear recollection of everything I listened to in the courses, but I know a transformation happened. I gradually became aware of 
some things. Words ceased to be ordinary information and became my own experience (excerpt from an interview with a student, 2017/2018 generation).

/.../ I noticed that after the Women's Studies programme I revised my basic views on society, on myself and my own choices, and on how I dared to say out loud some things I would never have dared to say before, that I was able to demand something, ask for something /.../ it was definitely a turning point in my education, if not in life itself /.../ (excerpt from an interview with a student generation, 2009/2010).

An important moment for a student's turning towards transformation, which on a personal level is often referred to as an act of articulation through voice, an act of self-awareness, self-knowledge or new knowledge, is part of the process in which knowledge of the self is contextualised, and in which woman is constituted as the subject of knowledge. Feminist positioning refers to two simultaneous inquiries: to articulation (Butler, 1997) through providing and creating stimulating, thoughtful, and provocative women's voices on diverse subjects from a woman's/gender perspective, and to "coming to voice", and both matter. Addressing voice as the place in one's own self where words have authority and by being recognisable - gain the recognition, "coming to voice" (Crary, 200I) refers to this very transformative momentum of shifting, a momentum of resistance where those who are marginalised become the agency of shifting events in favour of social change. While voicing, in a strictly Butlerian sense (Butler, 1997, p. 8), is an act of enactment, it can also be seen as an act of "ontological" solidarity with and among those who belong to similar subjugated or marginalised groups and communities. The process of self-reflection and articulation of knowledge through voicing and mutual listening defines the dynamic of educational practices themselves.

For me as a feminist who has been teaching feminist theories for more than two decades within both an alternative women's studies institution and within the university, critical pedagogy is an implicit avenue leading into feminist fields, almost its self-assumed presumption in the same manner as feminism is the self-critical process of re-reading and re-questioning theoretical areas, social reality and one's own position. More precisely, if the "/.../ challenge to scholars and social activists to push the boundaries of knowledge to go to new epistemological spaces", as clearly stated by Joe L. Kincheloe in his book Knowledge and Critical Pedagogy (Kincheloe 2008, p. 24), seems like a new demanding appeal nowadays, for feminists it has always been a way of thinking, breathing, feeling, existing, and disobeying hegemonic patterns of knowledge. Instead of an 
"epistemology of ignorance" that obscures, negates or distorts social realities (sex/gender realities, in particular) and its problems, several theorists (Boler \& Zembylas, 2002; Mignolo, 2007; Vargas, 2018, among others) developed the "epistemology of discomfort" as a counter-concept. Emerging from another ethics, it was the foundation for a "pedagogy of discomfort" which in the meantime became the basis for liberating ways of knowing. Although we have never actually so named the pedagogy that has been used in teaching Women's Studies, in many cases the practices have confirmed its use and validity.

The "pedagogy of discomfort" is briefly an explorative critical method and a tool for unfolding purported discomfort issues such as lesbian/ gay sexuality or sexual violence against women in order to understand the layers of obstacles, misunderstandings and the reasons for mimicry or silencing; or in order to see and act beyond the normal, namely, normative guidelines referring to hetero-normativism, beliefs or "habits of mind" linked to it. In other words, to see the world actively and consciously is to be made uncomfortable, if I follow this line of argument. According to Boler and Zembylas (2002, p. 2), this pedagogy engages students to enter into risky spaces of controversial ethical questions, calling them to critical awareness and action. Critical knowledge, according to them, is possible only in a "safe classroom" and by use of one's own emotional investment, when "collective witnessing" of experience creates a collective engagement which is recognised, known and felt.

On several occasions, I have faced this powerful momentum of collective awareness when violence against women was at stake, activating different aspects of personal and collective attachment, but also some very emotional breakdowns, intensified or unsolvable disputes among students. Nowadays, issues surrounding "sexual work" and prostitution signify such insurmountable controversy both among feminist scholars and students that it is unlikely to be resolved easily, if at all.

Nevertheless, liberating knowledge for feminists means not only making transparent all the models embedded in the relationship of subordination and domination, but a way to destabilise those relations or places that disenable a space for change by persevering on gender asymmetry and other epistemologically established power of matrice(s).

The education we are addressing here is always a project that deals both with the positional perspective that concerns women, gender, queer, or positional/political dimensions of one's own subjectivity as well as with the complexity of creative work in favour of social change, namely progressive social action. 


\section{Performing Feminism, Troubling Questions, Engaged Feminism}

What is an epistemologically reachable horizon when talking about the liberating of knowledge today? And, going back to Sternfeld's article and the timeless question: How can we radically change the circumstances from the inside? (Sternfeld, 2010, p. 5) These questions are somehow always on the feminist agenda, demanding very clear tasks from women's studies education. Education as a feminist (activist) project (Kašić, 2010) in the above-mentioned sense is the constant production of space(s) based on the principle of transversality that is created through the production of intersubjectivity, meetings, acts of experimenting, crossing over, new positioning and, on the other hand, seeking direct social engagement.

Before further elaborating on these issues, it is important to mention several obstacles that nowadays tend to block the politics of feminism as a liberating epistemology and/or engaged/activist theory. On one side, the politics of overgenderisation upon the feminist agenda that goes with the politics of gender mainstreaming as a rule exposed through "the politics of gender equality" holds the tendency for completely absorbing feminist content and disciplining and neutralising feminist critical demands. And yet a study presented in the article "Discursive Dynamics Gender Equality in Politics: What about 'Feminist Taboos'?" (Lombardo et al., 2010, pp. 105-124) shows how the application of the political concept of gender equality for more than a decade affects the process of depoliticising discourse on sex/gender issues and the scope of feminist engagement, and which has a direct impact on the production of feminist knowledge. Slovenian theorist Vlasta Jalušič significantly calls the implications of gender mainstreaming a process which, despite the initial intention, has directly produced "degendering" (Jalušič, 2009, p. 60). In academic institutions, it is obvious how the absence of the politicality of knowledge goes together with affirmation of the neutral categorical apparatus within the gender studies domain, and social sciences in particular. On the other side, there is the global commodification of knowledge which in a neo-global economy is encompassed in the "conflation of epistemic efficacy with pecuniary profitability" (Mirowski \& Sent, 2008), and for which neo-liberal narratives simultaneously produce competitive and expert-pragmatic knowledge often in the function of capitalist exploitation and financialisation. As a consequence, the problematic topoi of modern slavery, taking this as an example, marked by sex/gender and migrants of various kinds, human humiliation or the feminisation of poverty, enters into the array of educational interest only as an articulation of difference which, instead of a critical insight, is merely exoticised or trivialised. 
Of course, critical knowledge that engages feminist, antiracist or anti-colonial voices has nothing to do with this and accordingly is often marginalised within leading mainstream studies on projective streams towards globalisation.

Thus Judith Butler pointed out that:

It may be that knowledge will begin even more radically to circulate outside the university, and though there are many reasons to wish for the displacement of the university as the center of knowledge, it would be an unimaginable loss for the university /.../ (Butler, 2013, p. 190).

Along with the above-mentioned obstacles, there has been, according to Chandra Talpade Mohanty, the development of a "careerist academic feminism" in which feminism has become a way of advancing individual careers rather than a call for collective activism or radical transformation (Mohanty, 2003, p. 6). Do we still cultivate a politics of solidarity among feminist scholars and feminists in general as grounds for a feminist agenda, or is there no obligation beyond our professional positions and properly designed academic curricula?

In order to claim feminist alliances, we should rely on the places still left, or new ones that would enable a creative and critical feminist crossing. And yet, viewing the world today, the questions are becoming more layered and complex, and key feminist dilemmas by gaining new contours are becoming ever sharpened, and the feminist struggle more arduous.

A WS student recently asked me how to deal with "capitalist feminism". Although confused momentarily by this unusual question because it seems that everything is receiving a soft-fluid capitalist attribution and coating in a global world characterised by new-capitalist expansions, I quickly responded with a counter-question: "How to fight capitalism with feminist tools?". At that moment, I did not want to jump into an elaboration of the discursive paradox based on the very incommensurability between capitalism and feminism. Instead, I tried to make my arguments around the contemporary capitalist "empire" as a masculinist project and its global corporate brotherhood. The effects of global capital production directly attack women, making them disposable and cheap labour in order to make a profit (Gržinić, 2009). Not only is any pact that enables the continuity of modes of capitalist production founded on the division of labour and, in this regard, over-exploited female workers in the status of "modern slaves", but the exclusion of women as potential agency in this pact is conditio sine qua non of any capital logic and existence. These days where co-propriety between capital and power, working closely both nationally and internationally, functions "efficiently" by multiplying 
profits on the subjugation and exploitation of human lives and devastation of the human environment, feminist engagement in its acts must undergo a radical re-adjustment (Spivak, 20I2) and transformative process.

In one of her articles against the threatening conjunction of feminism and capitalism, Nancy Fraser (2013) draws attention to unfolding the three contributions of feminism to neoliberal development. First, by insisting on the goods of individual advancement, increased choices and family wage, feminism has in fact helped with "flexible capitalism", its decreasing job security, precarity and low-waged work, and female-headed households. Second, by turning to identity politics and sexism, "politicizing the personal" and "rejecting economism" (ibid., 2013), feminism coincides with the rising neoliberalism that is repressing both social equality and all memory of social equality. Third, by its continuous critique of welfare-state paternalism, feminism has contributed to free-market (corporate/financial) fundamentalism (via micro credits, among others), which adds extremely to inequality and poverty, especially among women.

It is therefore no coincidence that Marxist feminism has become all the more the domain for exploration in the Centre's programme, and shaped its syllabuses in the last few years. At the same time, it has become a place of confusion and often misunderstanding since the Centre's educators have not as a rule theoretically articulated this issue (Marxist political economy, precisely), or been deeply tempted by more specific economic inquiries that come out of neoliberal social realm(s). Since the programme has been shaped more around the interests of both scholars and students, mainly at the crossroads of cultural studies and feminist activism in a wider sense, but against violence against women in particular, and philosophical entries into the many venues of feminist knowledge, there are new challenging concerns that must be discussed. Besides the problematic points around "queering gender" and how it resonates with lesbian issues, women-oriented agenda or patriarchy, for example, there are fresh troubling questions that need to be answered.

How can we confront commodity feminism? How can we fight celebrity-branded feminism in which the voices of women emanate from the celebrity machine based on generally unquestioned gender/sex inequality? Or, how can we create feminist explanatory models that effectively resist women's job precarity are but some of these questions.

In this regard, a fruitful point of departure for feminism as critical agency right now might involve how we can articulate the importance of a subjugated perspective in rethinking the conceptual educational framework behind the dominant practices (economic/political/cultural), if I try to rephrase Kincheloe's concern (Kincheloe, 2008, p. 53), and at the 
same time how to enable feminists in performing engaged theory toward a just and equal society without the burden of the many emerging conflicting positionalities that contaminate feminist alliances. Are we ready for it?

\section{References}

Alvanoudi, A. (2009). Teaching Gender in the Neoliberal University. In D. Gronold, B. Hipfl, \& L. L. Pedersen (Eds.), Teaching with the Third Wave New Feminists' Explorations of Teaching and Institutional Contexts. Teaching with Gender. European Women's Studies in International and Interdisciplinary Classrooms (pp. 37-54). ATHENA.

Barada, V., Janušić, J., Kašić, B., \& Pešut, J. (2003). Institucionalizacija ženskih studija u Hrvatskoj - akcijsko istraživanje. Centar za ženske studije.

Bahovec, E. (2002). Feminizam kao epistemologijski projekt, Zarez, 4(80), 23. Retrieved February 5, 2020 , from https://bib.irb.hr/datote$\mathrm{ka} / 838442.080 . p d f$.

Butler, J. (1997). Excitable Speech: A Politics of the Performative. Routledge.

Butler, J., \& Athanasiou, A. (2013). Dispossession: The Performative in the Political. Polity Press.

Cornell, D. (1995). Rethinking the Time of Feminism. In S. Benhabib, J. Butler \& D. Cornell, Feminist Contentions: A Philosophical Exchange (pp. I45-157). Routledge.

Crary, A. (200I). A Question of Silence: Feminist Theory and Women's Voices, Philosophy, 76(297), 371-395.

Čakardić, A., Borić, R., Govedić, N., Kašić, B., Sibila, I. N., \& Simonović, K. (2010). Privilegiranje rubova: intervencije i prilozi feminističkoj epistemologiji. Centar za ženske studije \& Hrvatsko filozofsko društvo.

de Lauretis, T. (Ed). (1986). Feminist Studies/Critical Studies. Indiana University Press.

Evans, M. (2003). Killing Thinking: The Death of the Universities. Continuum.

Fraser, N. (2013). How feminism became capitalism's handmaiden - and how to reclaim it. Retrieved May I2, 2020, from https://www.theguardian.com/commentisfree/2013/oct/r4/ feminism-capitalist-handmaiden-neoliberal.

Gill, R. (2007). Postfeminist media culture: Elements of a sensibility. European Journal of Cultural Studies. Retrieved March 13, 2020, from https://doi.org/10.1177/1367549407075898. 
Gržinić, M. (2009). Capital, Repetition. Reartikulacija (16. December 2009), 8, 3-4.

Harding, S. G. (Ed.) (2004). The Feminist Standpoint Theory Reader: Intellectual and Political Controversies. Routledge.

Hemmings, C. (2008). Tunning Problems? Notes on Women's and Gender Studies and the Bologna Process, European Journal of Women's Studies, IS (2), I7-I27.

Hill Collins, P. (2009). Black feminist thought: knowledge, consciousness, and the politics of empowerment. Routledge.

hooks, b. (1996). Choosing the Margin as a Space of Radical Openness. In A. Garry \& M. Pearsall (Eds.), Women, Knowledge, and Reality. Explorations in Feminist Philosophy (pp. 48-57). Routledge.

Jalušič, V. (2009). Stretching and Bending the Meanings of Gender in Equality Politics. In E. Lombardo, P. Meier \& M. Verloo (Eds.), The Discursive Politics of Gender Equality: Stretching, Bending and Policymaking (pp. 52-67). Routledge.

Kašić, B. (20IO). Feminističke teze o prijestupima radikalnosti i politici spoznaje. In A. Čakardić, R. Borić, N. Govedić, B. Kašić, I. N. Sibila \& K. Simonović (Eds.), Privilegiranje rubova: intervencije i prilozi feminističkojepistemologiji (pp. I 4I-I73). Centar za ženske studije \& Hrvatsko filozofsko društvo.

Kašić, B. (2011). Feministička intelektualna klasa: Zebnje oko integracije ipolitika spoznavanja. In I. Radačić \& J. Vince Pallua (Eds.), Ljudska prava žena (pp.167-185). Institut društvenih znanosti Ivo Pilar.

Kašić, B. (2016). “Unsettling” women’s studies, settling neoliberal threats in the academia: A feminist gaze from Croatia. Women's Studies International Forum, 54, I29-137.

Keller, E. F. (1986). Making Gender Visible in the Pursuit of Nature's Secret. In T. de Lauretis (Ed.), Feminist Studies/Critical Studies (pp. 67-77). Indiana University Press.

Kincheloe, J. L. (2008). Knowledge and Critical Pedagogy: An Introduction. Springer.

Liinason, M., \& Holm, U. (2006). PhD's, Women's/Gender Studies and Interdisciplinarity. NORA - Nordic Journal of Feminist and Gender Research, I4(2), II5-I3O.

Lombardo, E., Meier, P., \& Verloo, M. (2010). Discursive Dynamics in Gender Equality Politics: What about "Feminist Taboos"? European Journal of Women's Studies, I7(2), 105-I24. 
Lugones, M. (2010). Toward a Decolonial Feminism. Hypatia, 25(4), $742-759$.

Mohanty, Ch. T. (2003). Feminism without Borders, Decolonizing Theory, Practicing Solidarity. Duke University Press.

Mirowski, P., \& Sent, E. M. (2008). The Commercialization of Science and the Response of STS. In E. J. Hackett, O. Amsterdamska, M. E. Lynch, \& J. Wajcman (Eds.), Handbook of Science and Technology Studies $\left(3^{\text {rd }} \mathrm{ed}\right)$ (pp. 635-689). MIT Press.

Mignolo, W. D. (2007). Coloniality of power and de-colonial thinking. Retrieved June 23, 2020, from https:/www.tandfonline.com/doi/ full/10.1080/09502380601162498.

Pereira, M. do M. (2017). Power, Knowledge and Feminist Scholarship. An Ethnography of Academia. Routledge.

Prügl, E. (2015). Neoliberalising Feminism. New Political Economy, 2o(4), 6I4-63I.

Rich, A. (1986). Blood, Bread, and Poetry: Selected Prose, 1979-1985. Norton.

Smith, D. E. (1987). The Everyday World as Problematic: A Feminist Sociology. Northeastern University Press.

Spivak, G. Ch. (2012). An Aesthetic Education in the Era of Globalization. Harvard University Press.

Sternfeld, N. (2010). Unglamorous Tasks: What Can Education Learn from its Political Traditions?, Journal \#1 4, e-flux. Retrieved May 20, 2020, from https://www.e-flux.com/journal/14/61302/unglamorous-tasks-what-can-education-learn-from-its-political-traditions/.

Squires, J. (2005). Is Mainstreaming Transformative? Theorizing Mainstreaming in the Context of Diversity and Deliberation Social Politics. International Studies in Gender, State \& Society, I2(3), 366-388.

Vargas, V. (2018). Women's Place in the Andes: Engaging Decolonial Feminist Anthropology (First ed.). University of California Press.

Zembylas, M., \& Boler, M. (2002). On the Spirit of Patriotism: Challenges of a "Pedagogy of Discomfort". Teachers College Record. Retrieved June 6, 2020, from https: //meganboler.files.wordpress.com/2016/o2/on_ the_spirit_of_patriotism_challenges_o.pdf, I-27. 



\section{Study in the Virtual Class: Doings of Feminist Pedagogy and the Covid-r9 Crisis}

Renata Šribar, Centre FemA - Institute of Transformation Studies and Agency, Ljubljana, Slovenia

\section{Introduction}

N any of us reflecting on our lecturing practices wish to deconstruct the ex-cathedra teaching, its symbolic dimensions and multilayered effect on our students. The presented inquiry reflects on contemporary and pandemic-related feminist pedagogy along with an explication of the author's own teaching practice. It is this applied side of my reflection that allows for switching over to the narrative "I".

The auto-ethnographic references I am using were obtained during precarious work engagement in tertiary-level education. In the study years 2019/20 and 2020/2I we, meaning my students and myself, have been and still are co-construing the studying process at the Faculty of Education at the University of Ljubljana in the subjects Gender specific socialisation, and Ethics and morals in science, and also at the Faculty of Social Work in the subject Gender and Violence in the Erasmus Programme.

After 5 years of teaching at Slovenia's public universities, I was certain that some intuitive pedagogic approaches are worth practising, and that this moment is the psychic milestone, indicating the personal need to enhance the two-way transfer of knowledge with new pedagogical inputs. The switch to digitalised classes, which was initially unwanted, has induced a step-by-step transition to the more structured integration of feminist pedagogy. Its elaboration under the special academic conditions of the anti-Covid-rg regimes has not only been my task but, as I was later informed, the effort of many feminist lecturers. Indicators of such endeavours are the surprisingly numerous blogs and expert Internet sources 
dealing with feminist pedagogy and digitalisation of the class during the Covid-19 crisis.

The first part of the discussion consists of my own modelling of feminist teaching, a summary of the characteristics of feminist and critical pedagogy, and the use of certain related theses. In the second part, a selection of feminist pedagogic Internet blogs and expert inputs related to virtual classes during the Covid-I9 crisis is integrated. Accompanying auto-ethnographic notes deliver my reflections on the personal spontaneous and informed approaches in virtual classes, which correspond to the feminist pedagogy guidelines disseminated via the Internet. The final part aims at an innovative subjective contribution to the contemporary feminist interventions in the virtualised studying processes and modes.

\section{Feminist Pedagogy, "Situated Knowledges”, Transformative Power}

After my initial teaching efforts at transposing all-the knowledge-youhave followed the transition to a more relaxed praxis. Over the next few years, I was developing certain unconventional approaches.

The traits of such seemingly spontaneous subjective realisations of the curriculum are shortlisted and sometimes accompanied by the respective objectives:

- addressing the students by feminine grammatical gender forms to practically demonstrate gender discrimination in language to the men present;

- $\quad$ addressing the students by their first names, and inviting them to omit use of the title professor while addressing me; I do not use any other formal language forms of addressing, which are formal, although I stick to politeness and kindness. The students may use the same mode while addressing me. Such interpersonal closeness is in my case much more realisable with the Erasmus students;

- unannounced transformations of the formal teaching plan to show how the actual socio-political or other socio-cultural actual phenomena and situations relate to a topic related to the study subject;

- $\quad$ reorganising a lecture room (if possible) so as to substantially subvert the unequal positions in the two-way transfer of knowledge. If not possible, I often take a seat among the students to make it easier for them to talk and share their thoughts;

- $\quad$ reporting my own experiences which relate to the exposed theses or topics; the aim is to practically illustrate that there is no real theory/ praxis gap. I do not apply pressure to them to expose themselves in 
the same manner. Besides, I try to interpret my experiences sincerely and in a dignified manner;

- suggesting that the students define their location at the intersection of social divisions, and survey their pre-existing knowledge of the research subject in the introductory part of the seminar or exam essay; besides, students are inspired to articulate a strategic plan to improve a social issue ("policy paper") in the conclusion of the essay;

- expressing an emotional charge when I feel it while theoretically confronting systemic and structural discrimination and exclusion; I typically explicitly relate such a display of emotions to the need for active citizenship;

- conceiving grades as a structural must, and trying to put more effort than usual into the descriptive evaluation of the students' work. When possible, I discuss together with the students their aural and written deliveries according to the pre-formulated criteria, and decide on each grade; and

- $\quad$ using certain themes with every study subject to formulate the basic epistemic framework needed; such thematic involvement is in line with the feminist knowledge and usable in every discipline, at least when studying humanities and/or social sciences.

Certain epistemic issues brought to light by feminist lenses restructure our perception of teaching and research. The following conceptualisations are the crucial theoretical tools I use to expose in all my lecture courses.

- "Partial objectivity", "situated knowledges", subject/object relation, and "positioning" (Haraway, 1999, pp. 298-309; Vendramin, 2009, pp. 64-66) in the study and research processes; these concepts are in opposition to thinking "traditional" objectivity and universal truth as epistemic facts.

- The knowledge-ignorance relationship, and the taxonomy of ignorance (Tuana \& Sullivan, 2006; Sribar, 2015, p. 50) and by analysing ignorance as a produced socio-cultural and political phenomenon of knowledge (science included) become transparent. The deconstruction of knowledge and ignorance implementing governmentality, capital, and gender perspective.

- The deconstruction of unjust socio-cultural hierarchies, academic institutions included; I consider hierarchies/axes of social divisions to be social constructions, which are the main structural and ideological/mental obstacles to the possibility of thinking human equality and equity. 
- The nature of experiences, which connect the known and the lived. By such implicit meaning of experiences, the dialectics of interpreting realities and experiencing them is revealed.

- The power relations and the three-level approach to research issues (systemic, structural, individual). All socio-cultural, political and psycho-social realities may be grasped by a consideration of different levels on which meanings, institutions and individual life options are construed. During lectures, I give examples of the patriarchal societies, their structures, and individual interiorisation and incorporation of gendered myths, social proscriptions, and cultural norms.

- The intersectional approach is introduced to enhance understanding and studying social inequalities. The complex discrimination which I present using mundane cases brings the normalised discriminating practices closer to the students, our own discriminatory practices, too. Besides, I promote the intersectional analysis as a self-positioning tool for the students while doing seminar or exam-related research.

- The deconstruction of dichotomies in mainstream thinking has a mind-opening effect in students. The regularly presented and analysed categorical pairs I refer to besides knowledge/ignorance are: nature/culture, global/local, private/public, mind/emotions, sex/ gender, representation (in the meaning of mimicking a reality)/ construction.

What seemed to be intuitive intervention in the curriculum and the phalogocentric pedagogic canon must be considered from the perspective of situated knowledges. The spontaneity in lecturing I have been practising has been embedded in the pre-existing feminist position and adopted knowledges. The feminism I have been subjectivated into was formed by individually selected readings, conveying the theses and arguments of feminist theories, and critical sociological and philosophical studies. The feminist scholarship was thematically and epistemologically accompanied by performing active citizenship. E.g. when studying and deconstructing pornography and the pornographisation of culture I was involved in civil society's endeavours to co-regulate porn. Consequentially, my self-positioning in academia and research has developed transformative features, I have learned to study, inquire, and teach with the defined and publicly articulated aims to transform the realities in the class and in my professional vicinity.

According to their feedback, feminist knowledge and interpretations of my own experiences have been stimulating the students' thinking. 
I have been inspired to look for theoretical references for my own praxis in feminist and critical pedagogy ${ }^{\mathrm{I}}$ and thus provide a firm theoretical sub-disciplinary basis for elaborating the existing teaching attitude and habits in class. Although my teaching subjects are of the SSH disciplines, not all teaching objectives and students' interests are restricted according to the MINT/SSH gap.

In his authorial introduction to the monograph The word to young people: Dialogue with the generation of active nibilism, Umberto Galimberti (2018) claims that apart from the study objectives the pedagogic stress should be put on the personal development and socio-cultural considerations of the students. An elaboration of skills and knowledges is needed for the inquiry into the contemporary socio-cultural conditioning of living. The university is determined by both socio-cultural and political conditions. Consequently, it should be in our pedagogic interest to define the macrosystemic order, the "grey zone" of the intertwined democratic and autocratic traits of our contemporary societies. This is the totality which encourages and at the same time supresses critical, oppositional feminist pedagogy. We have to deal with the intrusion of the governmental and international macro political and economy orientation which contaminates academia with autocratisation. The sensitivity to macro-systems, and the transpositions of these systems to national and global structural phenomena, inspire the interventions in the curriculum mentioned previously.

What has happened in Slovenia is that after a right-wing party won the by-elections, "Orbanisation" started in the first quarter of 2020 . The Slovenian "democratic erosion" (Lührmann \& Staffan, 2016, para $48^{2}$ ) has in its radical phase taken a form typical of contemporary de-democratisations: manipulative strategies performed without much effort of the executors to hide them; gradually intensified pressure on the media, state institutions and the public; a concentration of executive power in the patriarchy; the subversion of accountability and other values; capital requirements over nature and the destruction of national natural resources; the breaking up of the public health and education systems; complex militarisation; the promotion of a discriminatory discourse and practices in public life and politics together with other violations of human and citizens' rights; instability of work by way of massive precariousness, existential endangerment or anxiety due to poverty, violence towards gender and

I Most of the references used here are freely available. Precarious research work does not allow expenses for articles and books to be bought, which is a problem worth thematising on some other occasion.

2 The part "In democracies: the third wave of autocratization has a legal façade". 
sexual minorities, and paramilitary groups. The academic sphere, which is considered autonomous, has evidently been tackled by these processes.

In autumn and winter 2020, the degradation of democracy was nationally accelerated by the government's abuse of the anti-Covid-ig efforts with an autocratic discourse and measures directly and unnecessarily violating human rights and democratic fundaments. Public uncertainties and critiques in the media of the arguments used in support of such measures are based on the inconsistency of the measures and their insufficient effect. One of the most rigid measures is elementary school children's serious deprivation of in-situ school and free-time activities with their peers.

The governmental promotion of such anxiety and tension through the transparent production of uncertainty, ignorance and unintelligibility is reminiscent of Hannah Arendt's intellectual perception of the leading feature of governmentality in a totalitarian regime (Arendt, 1973, pp. 34-35). Paradoxically, the government's promotion of ignorance, and generally even the heyday of induced stupidity and the manipulative nature of the public discourses, is not corrupting students to any detectable extent. It seems that they are sensitised to social disadvantages because of their own poverty, primary-family problems related to substantial living uncertainties and the lack of future prospects in times of an economic and environmental crisis. During certain lectures at the Faculty of Social Work, most students could identify themselves as poor with regard to living conditions while we were discussing poverty. It was like the unexpected and the numerous coming out of the closet. When working on a methodology to ascertain how the discussion in a focus group should be carried out, two 20-year-old women students out of seven talked of tiredness and exhaustion. Their mothers had been unable to sustain their usual functions, and from time to time they had sought advice and lent completely on their daughters. Both students believed that the "daughter-mother roles are changed for periods of time, and it is tiresome to switch on and on from the daughter's role to mothering one's own mothers, and then be a daughter again." I told the two students that I was sad for them aware of the contradictory emotions, because that was the case. I tried to empower them to take a more autonomous position within their families. Before we parted company, I felt that I had given power and also received it. The feeling of gain was based on the idea that I had elaborated the skill of understanding and emotionally perceiving something psychical which has been going on between mothers and daughters forever. In the psychoanalytical framework, it is about an intimate and contradictory gender-identification process with daughters. With mothers, it is the socio-psychological framework which offers an interpretation related to the challenging 
myth of motherhood, which invites force and weakness in mothering. Immediately after that, we discussed the gendered socio-cultural conditions and the economy which are structural obstacles to the students emancipating themselves from the family traumas, equally those caused by structural problems.

The described ethnographic fragment may be provisionally formalised by the "triangulation" in feminist pedagogy with reference to knowledge production. The question of pedagogy is what or who is the central instance of the teaching and learning process. For the last three decades, the focus has been on students, as substantially presented by Carolyn M. Shrewsbury in her highly referential article "What is Feminist Pedagogy" (1993, p. 10). Schematisation revolving around the embodied focus may appear narrow in scope when the special subjective characteristics of teachers are desired, related to their "fundamental beliefs and values about teaching, learning, and knowledge-making" as stated in A Guide to Feminist Pedagogy (2015, para 2). It is one's beliefs and values that enable two-way communication and stimulate students' interests and inclinations. There are thus two instances, and in-between there is something which moves from one to the other and is in the meantime enriched. This moving entity is power which has to be shared. Yet there is no "subject" or characteristic of feminist pedagogy that is explicitly defined as mandatory and universal (Lawrence, 2016, para 6). One may conclude that there are ideas, but no strict guidelines. In her brief thematisation in Feminist Pedagogy in Issues, freely-attainable articles on the GEA - Gender and Education Association, Emilie Lawrence defines some features, "tenets", on which "there is common agreement": resisting hierarchy presupposed by the job itself by using experience as a resource, and transformative learning. The author warns us against reinforcement of the "dominant feminist narrative" by such an approach. Referring to my own praxis, I claim that the dominance of a selected perspective and discourse of a teacher deconstructed by referring to the human rights of gendered and other minorities, and to feminist ethics. I constantly try to stimulate discussions where I put the accent on the freedom to make informed personal decisions on what to think and how to live.

A fresh challenge regarding the ideas of feminist pedagogy thinkers and practitioners is detected in a novel aspect of the subject matter, accompanied by material objects. The concept of "object lesson" is inclusive of the non-conventional artefacts (Grensavitch, 2019, pp. 38-39) the teacher uses to inspire learning with exemplary materials in hand. In my appropriation of the concept, materiality is delegated to the body, it is inside and not exposed to the five senses of the others; it may be felt anyway. 
In our previously described case of the mother-daughter relationship, such an object consists of experiential value and gained knowledge, which are embodied by psycho-somatic experience in the two-way transfer going on between two equivalent instances, a teacher and a student, or a group of students. The sharing of experiences of the student/students and the teacher with the aim to articulate certain theoretic perspectives and interpretations is felt in their bodies. There are our embodied selves revolving around matrices of the unequal power relations women experience in the realm of private life. Such experiences are often reduced to a strongly felt psychologic interpretation, and in the mutual exchange of thoughts and emotions we become aware of the socio-cultural and political dimensions of the exposed interpersonal relationship.

The presented matrix of the "triangulation" of feminist pedagogy comprises the complex interrelation of student/students, the "object", a teacher, and has to be theoretically tested. "Object" is the subject matter vivified and substantialised by the force of attractive interpretations and sensations. The question is how to achieve conceptual stability of the hereby construed "triangulation". Mutual teaching/learning via the object of the embodied coupling of knowledge and experience is as follows compared to the argumentation of a liberating, democratised education. Carolyn M. Shrewsbury elaborated pedagogy in the framework of the embodied teaching/learning process by focusing on the conceptual tool for "overcoming oppressions", empowerment. The very concept of power comes from the affirmation of the Foucauldian discourse implicating embodiment. The problematic side of the idea of empowerment is that it conveys the meaning of a one-way transfer of power from the teacher to the students (Shrewsbury, 1993, p. I0). "Empowering pedagogy does not dissolve the authority or the power of the instructor. It does move from power as domination to power as creative energy" (ibid, p. II). Although the relationship of domination of the teachers over the students is interpreted as being deconstructed by "empowering pedagogy" and its reconceptualisation of power which is anyway constructive, there are two strong reasons to doubt such an interpretation. Teachers are subjected in the academic environment as are students, and they work and study in the same phalocratic and thus highly hierarchical structure. If they maintain the idea of authority and endow it with the embodied energetic message of the energy, they cannot deny the persistent unequal relationship of giving or offering and thus having and - as their counterparts - the receiving students, who do not have it, i.e. the energy and its benefits. Besides, the concept of authority is even not relativised. The fact that students have their own experiences which may inform "the instructor" when inquiring 
into a certain topic is ignored. And the students already possess adequate knowledges on subjects which are not known to the teacher. To avoid the implications of hierarchy and unethical power positioning in the form of a priori authority, the concept of empowerment has been criticised. In the field of social anthropology, Angela Cheater summoned the discussion on the problematic connotations of the concept by arguing that it might cover over the hegemonic power relations. Those who empower do not recognise the receivers' rights to define their own interests. By empowerment, they even construct them as being less able to do that (Cheater, 1999, p. 6).

The body active in the somatisation of experiences and the production of energy in the two-way teaching/learning communication cannot be devoid of its dual nature: it is described, mediated by discourse, and at the same time influenced by discourse. The pedagogic embodiments call for a collective investment in understanding the relation of the body with the symbolic and imaginary dimensions of gender-related discourse.

Just like Emilie Lawrence, some other authors consider feminist pedagogy an open structure which consists of an increasing "number of key practices" (Hassel \& Nelson, 2012). According to my comparison of expert articles and blogs on the doings of feminist pedagogy, and my own lecturing, described for the first time in the present discussion, I see identical approaches.

The similarities in personified liberating pedagogic knowledges and skills are intelligible. To practise feminist pedagogy, you need not become a scholar in the sub-field, it is sufficient to transpose feminist epistemologies to class. What might differ is the interpretation, anepistemology, and its applied imagination in response to the common denominators of feminist pedagogy. As stated, they are recognised by Emilie Lawrence, who questions the speaking dominant voices in class (2016, para 9). The consequence of the freedom in which feminism is to be applied to pedagogy are numerous options for interpreting and validating experience, and ways of using experience as a teaching/learning tool; similarly, the transformative teaching and learning is not prescribed in some universal form. This is the point of reflecting on my own pedagogic practice as logically unique: formulating a micro curriculum of the transferable feminist knowledge and skills to empower students in the field of informed active citizenship and human equality, and with the aim to let myself become powered by the students' questions, narratives and other contributions to the class community. I consider this relationship of equal importance as the reading of feminist texts; actually, it is stimulative for reading and making inquiry into new fields of feminist (trans)gender studies. The hegemonic voice of feminism in feminist pedagogy is deconstructed by the 
flexible positioning of the knowledgeable and powered subject(s). Or, as argued in the discourse of post-structural linguistics, the meanings produced in class are the product of the "floating signifier". The students are invited and stimulated to express conflicting and opposite arguments, and the studying literature is analysed critically in a comparison of contradictory theses in a text, and among texts.

\section{The Transformative Studying Praxes in the Virtual Lecturing of the Anti-Covid-rs Regime}

The transition from lecturing in the lecturing room to conducting study meetings in a Zoom personal room leads from initial discomfort to liberating effects. The experience of personal pedagogic enhancement has also been realised by the unique situation of working together with only five postgraduate students in different study courses at the Faculty, and executing a new subject Ethics and Morals in Science for the first time. In retrospect, I recognised numerous web references to feminist pedagogy, blossoming from the first Covid-ıs wave. In spite of well justified criticism of virtual studying practices, there obviously are certain stimulating moments in the evolutions of pedagogies as the sub-discipline is becoming even more pluralised. The problems and questions of feminist pedagogy have for many feminists been tackled with the new enthusiasm induced by the virtual space.

One must permanently question the possibility of establishing equality and equity in the two-way transfer of experiences, knowledges and skills. Institutionalised positions of teachers and students, socio-cultural expectations of role-related behaviour, and personal inhibitors of freeing and enriching the study are the challenges experienced. A related problem is co-construing the object of an emotionally-charged interpretation of experiences. My desire in trying to obtain the embodied, forceful interpretation of the experience is challenging despite the successes. The third issue in my use of feminist pedagogy is the constant doubt in the possibility of a transformative impact. All of these problems were highlighted from another angle defined by the virtual space. The most usual approaches to befriending students, described in the first segment of the present discussion could be sustained (e.g. addressing practice, two-way transfer of knowledge and experiences, benevolent and individualised assessment etc.). The materiality which seemed to be lost with the non-hierarchical reorganisation of the class appeared behind the screen already domesticated, and non-hierarchical as we all appear in the gallery of faces without any special position. The class has become cosier due to another factor: image. Students - a lot of them usually wearing heavy make-up 
- appear with no products on their face and in leisure clothes. Images, mine included, have lost importance and words have gained since there are fewer distractions. Zoom breakout rooms are dedicated to grouping the students into small units enabling a relaxed discussion without the teacher being present. Finally, each good-bye is performed in the vicinity of the faces, and the lack of corporeality is compensated by the friendly waving of hands. The mutual powering and transformation is moderate, verbally confirmed in larger groups by approximately one-third of the students. Their feedback consists of expressions like "I learned a lot", "this is new knowledge for me", or "I like the subject". When directly talking about the connectivity of our topics and the active citizenship for social change, my words are often reflected in the students' nods and inquiries into details of the case studies presented. My own transformations in the private and public realm which have been inspired by the students integrate an interest in feminist pedagogy, an elaborated skill of listening and feeling for the other, more patience and wisdom in reaction to the public scandals caused by government due to the government's totalitarian reactions against the protests of the non-parliamentary political left. The personality changes have not been planned or wished for. In the virtual class, I am more a moderator than a teacher, and the tenets of moderation are impacting my behaviour in and out of my professional role.

For the sake of a transparent presentation of the individual doings of feminist pedagogy in class, I am exposing the teaching and learning, i.e. the study experiences of my students, and my own. All of the ethnographic references were collected in the spring semester of the 2019/2020 study year, and the autumn-winter semester of 2020/202I while lecturing on Gender-specific Socialisation, Family, Women and Gender Studies, and Ethics and Morals in Science at the Faculty of Education, and the Social Sources of Poverty in Youth, and Gender and Violence in the Erasmus programme at the Faculty of Social Work, both at the University of Ljubljana.

The problem of deconstructing institutional hierarchy has been confronted by telling the students about the genealogy of my feminist subjectivation and professional status, and interpreting the basic feminist concepts, some in confrontation with the gender mainstreaming of the European Commission, and the contemporary domineering feminist discourse. The students have given feedback by exhibiting curiosity and the wish that more historical information about feminist movements be presented. In two-way communication, they have enumerated the most important bases of discrimination and oppression, and their awareness of 
everyday discriminatory praxes. Some of them have exhibited the wish to visit or engage in feminist NGOs.

The only obstacle has been ignorance as regards obtaining knowledge on deconstruing the persistence of gender mainstreaming in the interpretation of the gender/sex division. On the other hand, there has been a rewarding recognition of the alienation of women's bodies, whereby the reactions to this recognition were suitably diversified. In all debates, I have cooperated in a just manner, revealing myself in the role of a woman with certain demonstrated and discussed knowledges, skills and experiences, performing a certain role, and not in an a priori authority of a teacher. A teacher position has been humanised by the individualisation procedure and the decomposition of unjust privileges.

The description of the digital flexibility of web lectures and seminars has promoted the invention of less conventional and coded communication and praxis, and the situational introduction of actual socio-political topics not inscribed in the curriculum. One of these outer topics was "gender relations in the anti-Covid-r9 regime". Some already publicly known observations have been thematised, e.g. the accelerated occurrence of domestic gender-based violence, and new burdens of women related to elementary schooling at home (Finley, 2020, para 3). In the class for Gender-specific Socialisation, one student considered the curious occurrence - a non-sensible anti-Covid-Is measure determining the opening hours for the supermarkets. During the first pandemic wave, pregnant women were supposed to go to shop in the same time window in the early hours as retired and handicapped persons, while it was known that older people who got infected experienced severe Covid-Is symptoms (NIJZ - National Institute for Public Health, May 27, 2020).

The university, like other institutions during an autocratisation trend, is experiencing "executive aggrandizement" in that "elected executives weaken checks on executive power one by one, undertaking a series of institutional changes that hamper the power of opposition forces to challenge executive preferences" (Bermeo, 2016, p. I0). Yet, one might realise that the marginalized idea of democratization inspired a new unconventional consolidation of some teachers and students that has occurred in the anti-Covid-rs regime as well as the new comradeship and friendly support amongst the groups of teachers. At least I have had such an experience with some of my feminist colleagues, and there are reports from other countries, too (Dirik, 2020, para 7). These new phenomena of micro-democratisations and solidarity have intentionally or unintentionally been ignored in Slovenia, not thematised in public or professional circles. 
Something complementary to collegial comradeship and the most fulfilling micro-democratisation in teachers happened in a group of students with me as the teacher in the study subject Ethics and Morals in Science. It has not been easy to make the study hours in the heavily-loaded lecture and seminar blocks vivid and interesting. The decision to do auto-ethnographic inquiry into the research "object" which we chose together was crucial. The research on our perception of the "neo-liberalisation" of time and "time management" was multi-layered, the fieldwork had the nature of an experiment, which was organised individually according to subjective goals. When we reported on the results, quite intimate impressions were shared, which connected us well beyond expectations. One student became very emotional because she realised that her time had been spent in the neoliberal mode - her awareness being distracted away from the way the hours of her life had been spent. The emotional tension was released partially in class and later on after the lecture when she phoned me and explained her feelings in a private conversation. She said with a weeping voice that she was depressed, but anyway had the feeling that she had "gained a new insight, which might lead to greater respect for life."

While surveying the impact of Covid-19 and/or virtual teaching and learning on feminist pedagogy as thematised in web publications and journal articles, I have found various perspectives on the topic. The following paragraphs consist of brief excerpts of reports, analyses and guidelines, which I am able to illustrate with my own teaching practice examples.

Virtualisation of study in class is conceived as "the new normal". Experienced intertwinings of so-called private and professional life are reported by the author as tiresome and confusing (Oikawa, 2020, para I). In class, it may be different, the intrusion of domestic scenes, e.g. the sudden appearance of a partner or a child in the room or a dog, attracts new themes. In my case, what happened was a quick hug and kiss on the cheek of a student by her women partner. It reminded me that I was obliged to thematise gay and lesbian couples while discussing heteronormativity, and the illustrative value of the mentioned "intrusion" was adding quality to the lecture. As argued more than a decade ago by Nancy Chick and Holly Hassel, "failing to outline the many ways feminist pedagogy is applicable to online environments will ensure that myths and misconceptions about online teaching flourish and that only the worst versions of online pedagogy persist (Chick \& Hassel, 2009, p. 196). Another reference is derived from the technology and feminism sphere. "They call it 'distance learning,' but it can be intimate, horizontal, distributed, online, in real life learning" (Femtechnet, 2020, p. r). 
The relationship of the digitalised realities and the technical skills of students and teachers constructs students as a skilled entity in opposition to the lack of technological skills in the group of older teachers. As stated by the anthropologists Mariela Nuñez-Janes and Alicia Re Cruz, the online potential as regards adaptability "provides a way to develop and encourage the practice of student centred critical thinking" which foster the principles of "inclusion and legitimizing of students' voices and experiences" (Nuñez-Janes \& Re Cruz, 2007, p. 20). There are two features of the virtual which directly and indirectly construct students as a skilled and knowledgeable subject of study. In my case, the proverbial lack of technological talent in women and especially among older women became the ideal source which I purposefully and truthfully use to show the lack of skills and computer-related technical knowledge. According to the authors cited in the paragraph, such strategies aim "at igniting students' awareness of their value as knowledge producers" (ibid.).

Searching for a web document which would elaborate on a convincing and tested practice of feminist pedagogy, I detected the most structured thematisation of the virtual class in a newly published Sage blog written by Simona Sharoni. She offers a sensitive insight into some of the most important doings of feminist pedagogy: putting the stress on praxis and bravery in times of precarious work, informing the students that the personal is political and the political is personal (Sharoni, 2020, para 2). Her plan to "reimagine the virtual feminist classroom" has the transformative aim to "share power" (ibid., para 4), which I consider the basic and most transformative idea subversive of the patriarchy and the phalocratic organisation of institutions. Among the planned tasks to change the relationship between student and institution, I appreciate the idea of the self-assessment of the students of their work and grades (ibid., para 6). Since it is unclear if she has in mind individual assessment or students' mutual assessing, I am presenting my own praxis. It consists of an assessment of seminar work in a group of students where they mutually give each other feedback regarding the research contents, performance and contact with the public while presenting. These are criteria I have myself suggested and according to which the students decide on their grades with my help as they are hesitant to classify their peers' work in terms of quality.

Under the subtitle "Making a space for students to view the personal as political and the political as personal", Simona Sharoni explains the feminist thesis of second-wave feminism "personal is political" to the students in an illustrative and indirect way. One of the modes is to raise "critical questions that would allow students to identify key social 
and political problems underlying the crisis and the responses". When consulting with students on what to thematise for their seminar research and paper, I have offered them a few thematic options and, as described previously, we together make a decision to do individual research on time and the time pressure characteristic of neoliberal capitalism. In training and experiencing equity, I did the same research topic, although the methods were diverse. The results were generally the same. What is at stake are our lives and not only the quality of the time lived. We are not in a position of controlling our existence in time, the only existence we have. Control is mediated by capital and governmentality.

\section{Conclusion}

While structuring the teaching and learning praxis, one could apply the knowledge of a feminist epistemology origin and the experiences of feminist civil movements. The issue is that there is not one feminist epistemology and hence no dominant discourse. In spite of denying a fixed practice of feminist pedagogy, derived from the one and only referential feminist theoretical background, there is an undeniable resemblance in the diversified construing of feminist pedagogies by practical principles and guidelines. The reason behind this paradox is that feminist pedagogy is inspired by libertarian thought, i.e. deconstructing hegemony and power relations, protecting human rights, integrity and equality accentuated, and questioning the androcentric matrix of thought, with dichotomies being characteristic of its mode. Although most often not explicitly expressed, the aim of feminist pedagogy is to doubt the socio-political and cultural realities, as informed active citizens do. Knowledge as an objective of study is evident, and introducing experience and body is also in line with feminist epistemology and anthropology, philosophy and sociology. The common denominator of feminist pedagogy actually transgresses the sub-disciplinary and disciplinary limits of feminist pedagogy and gender or feminist studies. It is compounded of libertine, democratic ideas and gender awareness, all with defined thought forms integrated into all feminist reflections. Besides the mentioned hegemonic discourse, dichotomies which are reified, and power relations, the intersectional approach to discrimination and exclusion, and the constructions of knowledge and ignorance must be considered, along with a three-level approach to socio- political and socio-cultural realities (analyses on the systemic, structural, and individual levels).

The triangular composition in class where learning and teaching is performed by feminist pedagogy does not imply the question of where the focus should be. What is important is the object transferring to and 
from the instances of the teacher and that of the student or students. It consists of the subject matter and related experiences which cannot be accomplished without interpretation. The experiences reflect mind and emotions and through the latter it is and stays embodied.

The declared transformative aim of feminist pedagogy cannot be reduced to the objective(s) since it refers to society, and the ability of an individual or group to contribute to constructive social change. During the Covid-19 crisis and the measures against it, the virtual class has induced certain changes which may be considered transformative. The "intrusion" of the domestic space may stimulate the teaching and learning process, bring the individualities of students and the teacher closer together, and even make the categorical division public/private transparent in its construed nature. The screen decomposes the hierarchical organisation of the lecturing room, and the adaptive character of the digital programmes enhances students' autonomy by inspiring them to express themselves, while allowing them to exhibit their technical competencies and thus contribute to equality in the positioning of the teacher and the students. Both mentioned conceptualisations of feminist pedagogy - equality, and the two-way transfer of knowledge and skills - seem to be more ideals than realisable goals in the present pedagogic structures. As regards equality, a concept with a similar meaning might be more adequate. While "equality focuses on creating the same starting line for everyone", equity "has the goal of providing everyone with the full range of opportunities and benefits - the same finish line" (IWCA Calgary, 2017). The implied meaning of equity adds to realisation of the two-way transfer of knowledge and skills because it presupposes that the structurally weaker entity that the students entail obtains all the needed attention and resources to reach the position of a fair exchange of knowledge and transferable skills. Simultaneously, teachers should not be embarrassed to inform themselves with the help of the students on a subject they are more knowledgeable of. The intense studying process and reconceptualisation of the previously phalogocentric roles setting call for the renaming of teaching and learning as studying. The teaching function is transformed into moderation in the immediacy of naming. That is, the moderation implies the participation of those who already have the corpus of knowledges and are supposed to be skilled in different activities.

\section{Literature}

Arendt, H. (1973). The Origins of Totalitarianism. Harcourt Brace Jovanovich Publishers. 
R. ŠRIBAR • STUDY IN THE VIRTUAL CLASS: DOINGS OF FEMINIST PEDAGOGY ...

Bermeo, N. (2016). On Democratic Backsliding. Journal of Democracy, 27(1), 5-19.

Cheater, A. (1999). Power in the Postmodern Era. In A. Cheater (Ed.), The Anthropology of Power: Empowerment and Disempowerment in Changing Structures (pp. I-I2). Routledge.

Chick, N., \& Hassel, H. (2009). “Don't Hate Me Because I'm Virtual”: Feminist Pedagogy in the Online Classroom. Feminist Teacher, Ig(3), 195-215. Retrieved November 20, 2020, from http://www.jstor.org/ stable/40546ioo.

Galimberti, G. (2018). Besedo imajo mladi. Dialog z generacijo dejavnega nihilizma [La parola ai giovani. Dialogo con la generazione del nichilismo attivo]. Feltrinelli.

Grensavitch, K. (2019). Thinking with Things: Reimagining the Object Lesson as a Feminist Pedagogical Device in the Humanities Classroom. Theses and Dissertations. 2190. Retrieved November 26, 2020, from https://dc.uwm.edu/etd/2190.

Haraway, D. (1991). Simians, Cyborgs, and Women. The Reinvention of Nature. Routledge.

Hassel, H., \& Nelson, N. (2OI2). A signature feminist pedagogy:

Connection and Transformation in Women's Studies. In N. Chick, A. Haynie \& R. Gurung (Eds.), Exploring more signature pedagogies (pp. I43-155). Stylus.

Lührmann, A., \& Staffan, I. L. (2019). A third wave of autocratization is here: what is new about it? Democratization, 26(7), 1095-1113.

Sharoni, S. (2020). Reimagining a Feminist Virtual Classroom Amidst a Global Pandemic, -- SAGE Perspectives Blog April 8 (sagepub.com). Retrieved November 22, 2020 , from https://perspectivesblog.sagepub.com/blog/ reimagining-a-feminist-virtual-classroom-amidst-a-global-pandemic.

Shrewsbury, C. M. (1993). What Is Feminist Pedagogy? Women's Studies Quarterly, 3-4, 8-16. Retrieved July II, 2020 from https://pdfs.semanticscholar.org/daf2/cci 44aof679b59ea72265ac455c6e66c6f 77 . pdf?_ga=2.

Nuñez-Janes, M., \& Cruz, A. R. (2007). The pedagogy of teaching online graduate courses in the program of applied anthropology. Practicing Anthropology, 29(I), 20-23. Retrieved November 24, 2020 , from http://www.jstor.com/stable/24781694.

Tuana, N., \& Sullivan, S. (2006). Introduction: Feminist Epistemologies of Ignorance. Hypatia, 2I(3), vii-ix. Retrieved November 29, 2020 , from http://www.jstor.org/stable/3810947. 
Vendramin, V. (2009). Od kod prihajajo dejstva? Feminizem in transformacije nekaterih temeljnih epistemoloških pojmov [Where do facts come from? Feminism and transformations of some basic epistemological concepts]. Dialogi, 45(II-I2), 57-67.

\section{Internet Sources}

Dirik, D. (2020). Towards a radical reorganization of life. Resilience, A feminist response to the pandemic. Resilience org. Retrieved September 2, 2020, from https://www.resilience.org/ stories/2020-09-02/a-feminist-response-to-the-pandemic/.

femtechnet.org (2020). Feminist Pedagogy in a Time of Coronavirus Pandemic March 28, 2020. Retrieved July IO, 2020, from https://femtechnet.org/get-involved/self-directed-learners/ key-learning-project.

Finley, E. (2020). Editorial. Sept. 2. Retrieved July II, 2020, from https://www.resilience.org/ stories/2020-09-02/a-feminist-response-to-the-pandemic/.

Lawrence, E. (2016). Feminist Pedagogy, Gender and education association. August 17. Retrieved July I0, 2020, from http://www.genderandeducation.com/issues/feminist-pedagogy/.

Valle-Ruiz, L., et al. (2015). A Guide to Feminist Pedagogy. Vanderbilt Center for Teaching. Retrieved September 20, 2020, from https:// my.vanderbilt.edu/femped/.

NIJZ - National Institute for Public Health (2020). Napotki starejšim [Guidelines for the elderly]. May 27, 2020. Retrieved December, 16, 2020, from https://www.nijz.si/sl/napotki-starejsim. 


\section{Feminist Classrooms in Practice}

Ana Mladenović, Educational Research Institute, Ljubljana, Slovenia

\section{Introduction}

F eminist pedagogy is a theory about teaching that can be used in dif- pedagogy are built upon the core ideas that may be traced back to the emergence of critical pedagogy, which was a product of dissatisfaction with the relationship between schools and structural and cultural inequalities. These concerns guided progressive educators, such as Paulo Freire, in the late 1960 s and early 1970 s to criticise traditional pedagogies because they are authoritarian, limit the learner to a passive role in the teaching and learning process, and fail to produce a type of political knowledge that results in social action (i.e. that exposes and challenges the (re)production of oppressive (raced, classed, gendered etc.) relationships), as Audrey Thompson and Andrew Gitlin explain (1995, p. 125). The purpose of critical pedagogy was thus to alter the school's role in reproducing these relations by attempting to establish a more egalitarian relationship amongst pedagogical participants and enabling those typically silenced by schooling to become active and critical subjects. The transformative power of critical pedagogy can be seen in producing such political knowledge that allows for self-reflexivity of critical subjects' own position, which is of their alienation, along with the progress toward liberation (ibid.). This critical element is also an integral part of feminist pedagogy.

The nature of the content or which topics are deemed crucial is an important aspect of feminist pedagogy, as are its goals, materials and methods used. This paper, however, focuses primarily on the teaching 
and learning process itself, touching on issues regarding feminist classrooms. First, the transformative power of feminist pedagogy is discussed, as well as the concepts of empowerment, community and hierarchy. Then the focus shifts to questions surrounding feminist pedagogy in practice. Examples of feminist classrooms and practices on different educational levels are given. In the conclusion, some broader concerns regarding the vision of education, the role of the teachers, and feminist praxis underline the importance of feminist pedagogy and its inclusion in teacher training programmes.

\section{What is Feminist Pedagogy?}

Feminist pedagogy is a way of thinking about teaching and learning that guides our choice of classroom practices, specifically by providing criteria to evaluate different educational strategies in terms of the desired course goals and outcomes (Shrewsbury, 1987, p. 6). What are some of those evaluative criteria? One of the most important is the extent to which a community of learners is empowered to act responsibly toward the subject matter and each other, as Carolyn Shrewsbury points out. Even more crucial is the application of this knowledge and awareness to social action in everyday life (ibid.).

Feminist pedagogy is centred around the notion that all social relations, and thus all societal institutions and structures, are gendered. It is therefore hardly surprising that its key concerns are gender justice and imagining different ways to deal with and ultimately overcome oppressions (ibid., p. 7). Teaching and learning, as envisioned by feminist pedagogy, should challenge widely and uncritically accepted knowledge on which traditional theories are based on (Forrest \& Rosenberg, 1997). Feminist pedagogy calls for a change. In this sense, it is a transformative pedagogy. Its transformative component is multilayered and the drive for change constitutes different aspects of feminist pedagogy, for example:

- its vision: What is education? Even more importantly - what it could be (and is often not)? (see Shrewsbury, 1987);

- $\quad$ its learning: Is gaining new knowledge truly enough? Or is it just as important to shift our thinking in new directions? (see Lawrence, 2016);

- its methods: In which terms do we understand the structure of the classroom? Is there a divide between teachers and students or are they all class participants? How does the change in understanding of this relationship affect the teaching methods and practices used in the classroom?; 
- $\quad$ its materials: What are acceptable learning materials? Is literature the only valid learning source? How can personal interpretations and experiences of social phenomena enrich teaching and learning environments? and;

- $\quad$ its goals: Is learning enough or is there a need to apply the acquired knowledge in day-to-day life via social action?

The transformative power of feminist pedagogy is seen in the efforts to create teaching and learning experiences that aim to overthrow the status quo, by asking alternative questions regarding human experience. Feminist pedagogy thus requires a major shift in perspective (Forrest \& Rosenberg, 1997). "As feminist teachers attempt to transform educational institutions, they are restructuring their classrooms with the guidance of feminist principles," as Linda Forrest and Freda Rosenberg note (ibid., p. I83). They recognise six broad categories of feminist commitment to educational transformation in their literature review:

- integrating educational dichotomies;

- rethinking power and authority;

- creating communal classrooms;

- respecting diversity;

- $\quad$ integrating the knowledge of personal experience; and

- $\quad$ incorporating social action (ibid., p. I84).

Keeping all that in mind, one of the main goals of feminist pedagogy, characterised by engaged teaching and learning, is to create the classroom as a liberatory environment in which, as Shrewsbury (1987, p. 6) notes, "we, teacher-student and student-teacher, act as subjects, not objects". This goes hand in hand with another tenet of feminist pedagogy: resistance to hierarchical structures. In the learning environment, the teacher and students work against the creation of a hierarchy of authority. One way to resist hierarchy is by empowering students to deliver their own content and influence the design of the class (Lawrence, 2016). The goal of such classrooms is that all members learn to respect each other's differences by building on the participants' experiences in a participatory, democratic process in which at least some power is shared (Shrewsbury, 1987, pp. 6-7). This environment is active, not passive, it enables students to take risks and supports values of working together as well as achieving both shared and individual goals. It promotes the application of critical thinking as a reflective process grounded in experiences, while respecting and working with others (ibid., p. 7). Feminist pedagogy strives to create a community "where there is both autonomy of self and mutuality 
with others that is congruent with the developmental needs of both women and men" (ibid., p. Io). In such a community, the personal can be recognised as political since it nurtures a need and sparks a desire to move learning beyond the classroom. It creates a circular motion, theory can be applied to action and experiences that are a result of social action can likewise inform theory, which may yet again lead to new action (ibid., p. II). One of feminist pedagogy's goals is thus to create a community that engages in feminist praxis.

Another important concept in feminist pedagogy is empowerment. Although power is a concept usually tied to critical reflections of domination in feminist theory, empowerment expresses a concept of power as a capacity and potential rather than as domination. When power is defined as a capability, the goal is to increase the power of all actors, not to limit the power of some (ibid., p. 8). In feminist pedagogy, there is a tendency to eradicate points of power and disperse the power among the classroom. Still, this does not mean that the teacher's authority is dissolved, as Shrewsbury notes (ibid., p. 9). His or her position is more reconceptualised as a source of power by way of creative energy, not domination. As Jennifer Gore (1993, p. 79) would argue, the feminist teacher becomes more of an authority with the students than an authority over the students, that is, less didactic and more collaborative since knowledge is shared rather than imparted (Bignell, 1996, p. 316). Feminist classrooms are therefore interactive, encourage a de-centred approach to teaching and the learning process and especially focus on the critical assessment of differences (McKenna, 1996). This approach helps validate the experiences of all students, especially women, since feminist pedagogy is based on the perspective that educational environments have traditionally been sites of patriarchal power that have neglected the experiences and perspectives of women (Freeman \& Jones, 1980; see also Bignell, 1996, p. 316).

\section{Feminist Pedagogy and its Critiques}

One of the biggest challenges in outlining feminist pedagogy is to resist a single, dominant, institutionalised narrative, as Emilie Lawrence (2016) describes. Rather than defining feminist pedagogy as a single, fixed list of characteristics, we should allow for the possibility of different feminist pedagogies, fragmented and continually developing practices that invite teachers and students to contribute to their evolution (ibid.).

Feminist pedagogy is therefore self-reflexive and critical of its own theories. Reflexivity is in fact built into the tenets of feminist thought, meaning the critiques and questions are better understood as a means of development. Challenges to feminist pedagogy include queries about: 
- resisting hierarchical relations: Is resisting hierarchy even possible in situations where one party is paid to be assessing another? How can equality be achieved in the classroom and in student-teacher relations?;

- $\quad$ using experiences as a learning source: Who has a voice and is able to speak out? Are all voices equally present? Which aspects of experience are hushed by the dominant voices of the classroom? How can students and teachers incorporate their private experiences into their professional relationship? and;

- transformative learning: How can ways of thinking change in an institutionalised learning environment? What are the possibilities for a change in the ways of thinking? Can this transformation be viewed in negative terms? (ibid.)

\section{Feminist Pedagogy in Practice}

Before providing some examples of teaching and learning as conceptualised by feminist pedagogy, let us turn our attention to the content that fits into feminist pedagogy by meeting the broadest criteria of the following basic feminist principles. Teaching feminism addresses issues like: sexism, gender dynamics, power relations, structural inequalities, intersecting differences, hierarchy, patriarchy, gender-based violence, homophobia, transphobia, sex education, gender stereotypes, gender representations in media and popular culture and many more. This list is incomplete and intentionally broadly set to cover different social arenas. Just how much feminism has to give in regard to a critical reflection of society as a whole may be inferred from the extensive list of feminist interventions in a single social institution, the school. Focusing on the educative process, feminism reflects the issues of gender inequality in education such as gender stereotypes, school-related gender-based violence, the feminisation of teaching, the masculinisation of tertiary education, gender and achievement, gender and dropout, gender segregation in educational choices, gender-specific learning styles, gendered curriculum, gender-specific disciplinary practices, gender-specific pedagogical approaches and methods of teaching etc. Again, the list is not complete.

However, the purpose of feminist pedagogy is not to teach feminism by focusing solely on issues regarding gender, but to incorporate basic feminist principles and values (for example those of solidarity, empowerment, cooperation and justice) and feminist ethics, based on the importance of personal experience, context and nurturing relationships (see Kavka, 2007) in the teaching and learning process. Thus, feminist pedagogy can be used in different ways within and across many disciplines. For 
example, building a community by promoting group work follows feminist principles, yet at the same time is a very universal method for gaining new knowledge. Even in science classes, feminist pedagogy can offer new ways of comprehending knowledge and different starting points for learning and teaching science. Using elements of feminist pedagogy thus benefits student-teacher relations and classroom experiences, even where issues regarding gender are not specifically addressed. Examples of such feminist classrooms and practices are given in the following chapter.

\section{Feminist Classrooms}

Feminist classrooms are classrooms in which elements of feminist pedagogy exist in the teaching and learning process. This may be classrooms that teach (about) feminismi as well as classrooms where any other subject is being taught, as long as they are liberatory environments, following the basic principles already outlined. In the following sections, the importance of feminist pedagogy is highlighted for different levels of education: preschool education, primary level and secondary level.

\section{A Word on Method}

Some of the practices presented were acquired during the literature review, but the majority of feminist classroom practices discussed on the primary and secondary levels were procured during a semi-structured interview with a teacher in training. $\mathrm{Nina}^{2}$ is a 26 -year-old student finishing an MA in ELT (English Language Teaching), with 2 years' experience working in different educational settings teaching students who attend the third and fifth grades of primary school, as well as secondary school students. She meets with primary school children weekly in a classroom setting and teaches a few groups of students on the secondary level, but chiefly works with secondary school students individually in a classroom setting. She defines herself as both a feminist and a teacher. She is hesitant to call herself a "feminist teacher" as she believes she does not have the sufficient insight into feminist pedagogy. However, she is a feminist and her "teaching stems from who /she is/ as a person", meaning that it is influenced by her beliefs, values and norms. Even though her goal is not to actively create feminist classrooms, the end result is often a feminist teaching and learning situation since her methods and approach are often rooted

I These are mostly found on the tertiary level and include Gender Studies and Women's Studies, for example. However, teaching feminism (and especially teaching about feminism) is not necessarily limited to universities, it can also be (and often is) incorporated into courses in primary and secondary schools - for instance, Sociology, History, Philosophy, Literature and Art. 
in feminist pedagogy principles. The interview was planned and conducted as a qualitative research technique, via Zoom, to explore her thoughts, perspectives and, most importantly, experiences of teaching. The interview was then transcribed and parts of it are included in the sections below. It is clearly stated which of the examples shared come from the literature and which are Nina's experiences.

\section{Preschool Education}

Feminist pedagogy holds the potential to greatly enrich early childhood education by providing an alternative outlook on children in the most intensive phase of their cognitive development. Feminist classrooms on the preschool level base their methods on gender-sensitive and feminist pedagogies. One of the usual starting points in such educational environments has to do with the constructions of gender. Activities include different ways of challenging children's preconceived notions of femininity and masculinity, gender stereotypes, traditional gender roles and gender relations. These may include role-play, learning about different occupations, offering a diverse range of toys and encouraging children to choose gender-atypical toys or even choosing not to give any specific cues to children so as not to risk influencing their choices or behaviour with the teacher's (often unconscious) preconceptions, instead providing the background, posing challenging question $s^{3}$ and ultimately letting them make their own decisions. Preschool may be critically assessed as a "system of gendering factors" (Karlson \& Simonsson, 201I, p. 28I) that shapes children's minds but it also has the potential to empower children by building on personal experience and offering alternative ways of teaching and learning. Kristina Andersson and Annica Gullberg (2012) describe a brilliant exploration of how two different epistemological perspectives on the same teaching and learning situation ${ }^{4}$ generate different outlooks on which kind of science teaching competencies may be beneficial in preschool settings. In the first perspective, the central goal of science teaching is the development of a conceptual understanding. In this view, the purpose of science activities with younger children is to provide them with opportunities to practice a scientific way of thinking by using scientific concepts. The floating-sinking experiment was unsuccessful from this perspective of learning science. Children mostly did not acquire new concepts or misunderstood certain science concepts; the situation even enhanced a "misconception"

3 It is important that questions are posed in a way that is adjusted to children's current cognitive level, yet still challenges their line of thought.

4 In this case, it was a floating-sinking experiment in which the children throw different objects into the water and observe if they float or sink. 
concerning density. Some children seemed to have acquired new concepts but in fact did not understand what they imply or how to use them correctly in scientific contexts. The teacher, in this view, did not support the children's conceptual learning because she did not follow up on their conclusions or discuss them further or in any greater depth, she also did not introduce concepts in a scientifically correct way. One explanation may be that she did not fully understand the concept of density. Indeed, preschool teachers are required to teach science, yet often do not possess necessary knowledge, as research shows (see ibid., pp. 277-278, for an extensive overview). They have insufficient subject matter knowledge, which limits them in answering children's questions about complex natural phenomena in a scientific way accessible to young children. Low levels of subject-specific knowledge also result in low self-confidence and reluctance to teach science. But Andersson and Gullberg propose that, instead of regarding teachers as the problem, it is worth ensuring that researchers e.g. "investigate what happens if the natural sciences per se and /that/ the view of the sciences are scrutinized" (ibid., p. 278). "This becomes possible when using the second perspective, defined by a feminist approach, where the floating-sinking activity is investigated by focusing on whether it contributes to a feeling of participation in a scientific context for the children and, if so, what is the teacher doing to promote this inclusion. This view examines the potential held by preschool science activities in developing values and knowledge other than children's conceptual understanding. This perspective showed that the children's scientific proficiency benefited from the situation and that they had a positive experience with density, which was reinforced by the teacher. By using the experimental approach and having some freedom to experiment on their own outside of the teacher's structure, the children discovered that they possessed power over their own learning. The teacher had an important role in challenging and encouraging the children in learning science. These findings show

5 One girl used the word "experiment", but did so in a way that did not make sense.

6 The dominant view of scientific knowledge as value-neutral and context-independent is partly a consequence of the many technological and medical advances which have helped secure the natural sciences' status of authority in the twentieth century in Euro-Western societies (Keller \& Longino, 1996, in Andersson \& Gullberg, 20I2, p. 278). This dominant view had been questioned, however, by feminist scholars like Donna Haraway (1991) and Sandra Harding (1986), who had argued that the natural sciences are culturally situated and hierarchically organised. Feminist science education researchers emphasise the importance of cultural aspects of learning. They are curious about which knowledge counts as scientific and why, while stressing the importance of active reflection and informed and engaged criticism of: the social construction of science; the impact science has on society; and of the power dimensions in the scientific community (Hildebrand, 200I, in Andersson \& Gullberg, 20I2, p. 278). 
that when preschool teachers engage children in scientific activities, it is not just the subject matter knowledge that counts, other competencies are equally important. These other competencies include paying attention to and building on children's previous experiences; capturing unexpected things that happen on site; asking challenging questions that stimulate further inquiries and creating a "situated presence" or giving the space to the children and simply listening to their explanations (ibid.). All of these situations create teaching and learning moments in feminist classrooms.

\section{Primary and Secondary Education}

Feminist classrooms are active classrooms that engage students in group work activities and empower them to take control of their knowledge by enriching classroom discussions with ideas and information from the outside world. As an English teacher, Nina stresses that language teaching and learning is a specific environment where the ultimate goal is to get the children to talk and converse with each other. The best way of encouraging students, especially teenagers from the third triad of primary school upwards, to talk is by asking them questions about themselves, focusing on their personal experiences.

Each topic we cover, you have to ask for their opinions, what they have done in their lives that makes them think so. Focus on their lived experiences and not on the articles that are presented in textbooks.

One of Nina's goals is to promote civil discourse, creating situations in which the children work as a unit. Her classrooms are always open to group discussions, which she believes are one of the best teaching and learning situations for helping to improve students' critical thinking, a skill that is important in educational settings as well as in other areas of life. She discovered that essay writing is easier for the students when the topic they have to write about has previously been covered in a way that includes their own experiences. Drawing from experience therefore benefits students as it holds the potential to enrich the learning material, process and outcomes, but it is also a positive teaching practice that can enhance the work of teachers. Nina talks about her personal experience and how it has shaped her teaching.

When students take tests, they sometimes come up with answers that you did not expect, but that grammatically work. I like to bring attention to those and go 'this is what I had in mind, a student /... / wrote down this, which works perfectly here. Why does it work? What made them think of that?' /... / This is /.../ because of my personal experience, when I didn't know how to spell baggage in high school, so I 
wrote down carry-on and my professor refused to give me a point because it was not a word we had covered in class.

The beginning of every lesson with her secondary school students is reserved for something Nina calls "life update". This is an activity that works well with small groups in which students are given a chance to tell everyone what they did over the week. ${ }^{7}$ This opens up a discussion in which all students participate, mostly by asking questions. This activity helps on three levels:

- It builds a better classroom climate. This is especially true if the children had a test before. "Life update" helps break the tension and enables the students to relax or, as Nina explains, "to be humans before they have to be students again". It also helps because it allows the students and teacher to come to know each other better. It gives some cues about the personal lives of the students that might have an impact on their current mental state. These cues are important to the teacher so that he/she knows how to structure the class (for example, the teacher may behave differently if they know that a student's family member has just died).

- It helps with student-student relations: they get to know each other better by asking simple questions about the everyday life of their peers and are hence more open to participating in other classroom discussions, even those that cover more serious or controversial topics on a deeper level.

- It helps with student-teacher relations: students believe that the teacher is genuinely interested in their experience which in turn makes them likelier to share.

Nina in this context says that the students: "stop seeing me as an authority and start seeing me as a peer". We would argue though, in line with Shrewsbury (1987), that this activity does not undermine the teacher's authority, but moves the conception of power as domination to power as a creative energy. It is therefore an empowering activity that "provides a

$7 \quad$ While "life update" has some upsides, which will be discussed, one possible concern entails different levels of student willingness to participate in such an activity. Not all students automatically want to share their everyday lives with others. Nina explains that, as an English teacher, she likes to use it nonetheless since the main goal of this activity is to develop speaking and listening skills. "I accept answers such as 'Yesterday I took a long nap' or 'Nothing special, really'. I don'tforce students to participate if they don't want to, but I encourage them and invite them to." Respecting the students' choice to share or not to share something is an important part of feminist pedagogy as it builds better student-teacher relations based on trust and mutual respect. Not forcing to share also helps create an environment where students feel safe and are in turn perhaps more likely to speak up in the future. 
model of interrelationships that can be incorporated into a developing vision of a world in which hierarchical oppressive relationships are exchanged for autonomy within a community that celebrates difference" (ibid., p. 9). Empowering students by resisting hierarchical in-class relations and building a community is something that can be seen in another practice Nina says she employs, that has to do with making and correcting the mistakes. She often makes grammatical mistakes while teaching students in fifth grade and those attending secondary school. These mistakes are generally intentional and used as potential moments where power relations in the classroom could be shifted. At the start of each school year, she tells the students to let her (and everyone else in the class) know that she has made a mistake if they notice one - which they do, once they become a little more familiar and comfortable in class. This is a great example of utilising the notion of power as a capability as it creates a dialectical relationship between the teacher and students. Or, in Nina's words:

\section{Because if I'm the one correcting their mistakes, I also want them to feel in charge of their knowledge when they spot the mistakes I make, right? /... / We're all here to learn.}

When students make mistakes, she tries not to correct them too often or aggressively. If somebody persistently makes the same mistake, she uses it as a teaching moment for the entire class to work on and to correct collectively. Another way she resists the hierarchical structure of the teacher-student relationship is by rarely providing the solution to problems: "I don't want them to see me as a source of knowledge /.../, but a facilitator". She has noticed that it is easier for students to internalise the rules and they also self-correct more efficiently provided that she only manages the discussion instead of leading it. When children have questions, she does not answer them immediately, instead pausing and letting them come to their own conclusions. She encourages peer-to-peer teaching and helps them if they struggle. She believes that the key to building a better classroom climate is to apologise to the students if the situation calls for it. These are all in-class micro practices found in feminist classrooms that work together to deconstruct hierarchical relations.

Feminist classrooms make a point to notice the specific contexts of the teaching and learning process, but also more generally to try to contextualise different concepts and phenomena in specific social, cultural, political and economic spheres. Nina explains how, especially with her secondary school students, she sometimes brings up her genuine mistakes that she did not notice at the time, in the following lesson. They then discuss the reasons for those mistakes: 
We also talk about why we make those mistakes, so what is the specific cultural environment in Slovenia that results in us making such mistakes. I like to classify the mistakes we make in two groups: this is something that native speakers do as well, and this happens because of transfer, because of the specifics of our language.

Nina's teaching is also shaped by the structure of the classrooms. The basic principles of feminist pedagogy are present in all her classrooms, but the teaching methods are adjusted to the specific group of students. She mostly focuses on the students' age when she talks about different teaching and learning situations. Discovering mistakes and advanced discussions are mostly reserved for older students because cognitively and language-wise they are capable of participating in such activities. That does not mean that classrooms with younger students are not active classrooms nurturing social agency. Nina describes a project with students from the third grade, where they dedicated a week to talking about empathy. Her goal was to try out some activities that English teachers do not usually participate in, centred around the notion of empathy and promoting a better classroom climate. She picked a children's book on the said topic and decided to use a method of language teaching with non-verbal activities since children so young are still not able to have a discussion about read material.

I set up a story time nook and had them sit on the pillows, be very relaxed, have this good classroom atmosphere and I read them a book that was difficult for them language-wise /... but the content was based around the concept of empathy and was more relatable, as it followed a simple structure, familiar to children. We also stopped and talked about it in between pages. I... After the story was over, they started drawing /... they had complete freedom, they just had to include something from the book or something that reminded them of the book. I expected them to start talking and they did, they started talking about a different language they can use when talking about somebody and when talking to them /... / and why it is nice to use some words and not nice to use others /.... They got into disagreements about whether specific words are nice or not and held a conversation on a deep level, cognitively pretty advanced for third-graders. They started talking about why it is important to be nice. The whole concept of empathy really came out during that lesson.

This activity also helped with managing the behavioural problems of some students in the class, especially three boys, who are very rowdy and disruptive.

Their behaviour during that lesson was completely different from how they usually behave. I think it is because of the classroom climate, the other students really egged 
them on. .... When the classmates started borrowing rulers or pencils and sharing with each other, the three boys started offering their stuff as well, which is something they had never done before. ....

Another positive outcome of the empathy lesson and one important in the context of feminist pedagogy involves the use of non-verbal activities, which is a good way of teaching and learning concepts, as Nina explains.

Children lack the vocabulary to really get into the concept of empathy, but they can talk about how it is important to be nice to people, to understand where they come from. They don't have the words, but they have lived experience. Sometimes, it is beneficial to ignore the words and let them express their lived experiences as they want to - could be through drawing, dancing, other language... You need to rely and lean on the lived experience of the children.

This ties into what feminist pedagogy can contribute to the teaching and learning process in the same way as was discussed in the case of the floating-sinking experiment of Swedish preschool children. Classrooms should be more than just places where conceptual understanding is being developed, focusing instead on a range of different competencies and building new knowledge from them. This is what Nina discovered when evaluating the lesson on empathy.

If we look from a language-learning perspective, it was the worst lesson I have ever had. .... But if we look at it from another point of view, the kind of climate it created I... and the following lessons... The three boys who hate English and are usually not engaged or disrupt the others - they were calm, they were great, they were relaxed. Their interest in English increased. I... The effect it had on their continued success as a group and as individuals made that lesson one of the best we had.

Travis Bristol (2015, p. 62) describes the case of disengaged and underachieving boys and their grade- 8 teacher. He uses the term "gender-relevant pedagogy", but essentially depicts a situation that may be seen as an example of feminist pedagogy in practice. The boys were uninterested in the content the teacher was attempting to deliver and were talking incessantly about video games. Bristol suggested that she could try to re-engage them through their interest in video games. Instead of prohibiting the boys from talking about their interest from outside the classroom, he suggested including the complexity of video games in the content. This method worked and underscores the point that feminist pedagogy practices (i.e. building on personal experiences and interests) can help when students are not engaged or struggling academically. Nina says that in her 
experience the best way of connecting to the personal interests of children is to let them take on the teaching role.

\section{If I want to engage a student who only cares about football, I would not bring in an article about football. But I would ask him questions about football, make him be the teacher, make him tell me things.}

As we can see, the active engagement of students is an important element of feminist classrooms. Once the students are engaged, it is up to the teacher in which direction to go. Nina talks about the importance of group discussions in shifting the thinking in new directions. New ways of thinking can also have a significant role in the context of social agency.

I think that learning doesn't finish in the classroom, you have to take ... both ... the actions you learn in the classroom out there and you have to bring the outside into the classroom. It goes both ways.

Moving learning beyond the classroom creates a praxis, defined by the circular motion of mutually informing theory and action that Shrewsbury (1987) mentions in the context of creating a learning and teaching community, where the personal can be recognised as political.

\section{Conclusion}

If equity and equality are among the main goals of educational environments, then gender is a topic that must be addressed, constantly and in different ways. Feminist pedagogy offers a good starting point for such discussions as it facilitates the use of positive practices that create active, open and communal feminist classrooms which integrate educational dichotomies, rethink concepts of power and authority, respect diversity, build on personal experience, and demand social action.

Pedagogy must be understood as potentially reproducing power relations, as David Lusted points out, noting the contradictions in its content, which call for change, and its form, which reproduce the existing relations. To connect the learning with actual change in consciousness, namely - to transform theory into practice - requires a constellation of open-ended and specific pedagogies sensitive to context and difference, addressed to the complexity of experience constituting any student's or group's "gendered, raced, classed, aged and discrete biographical social and historical identity" (Lusted, 1986, p. I0). From the teachers' perspective, this means that their role in feminist classrooms is to help students find the language for the different experiences they bring in with them, to understand the wider social, cultural and political context of their 
individual positions and to facilitate social action. All of this is contingent on a broader understanding of what education is and should be. For Nina:

/... education is not something that happens in the classroom - in the classroom you sort of things that you learn elsewhere and that you bring in with you from the outside. The role of the teacher is to guide the students through thisprocess, help them in becoming self-sufficient and capable of using the knowledge for what they need, critically assess which sources to trust, expand their ways of thinking about the world... Make them into well-rounded people and not just providing knowledge.

Teachers have the means to create a platform for the students from which they can grow as individuals and as a community, providing a framework in which to organise, understand and contextualise personal experiences. This is why introducing feminist pedagogy into teacher training programmes is especially important. Of course, we should not minimise the effect of the many restrictions, regulations and curriculum constraints, which often leave teachers unable to freely choose what and even how to teach. But empowering future generations of teachers with knowledge about the positive effects of liberatory pedagogies means they will be more likely to expand their teaching methods and actively include at least some feminist pedagogy elements in their teaching. Still, it is not just about informing them with materials on this content or theoretically introducing the topic, it is also about practice. This means taking it one step further and actually consciously using feminist pedagogy in the same teaching process that teachers-to-be participate in. As Lyn Robertson (1994) notes, preparing teachers who have learned to use feminist pedagogies is one way of breaking the cycle of male-dominated, hierarchical pedagogies, especially given that teachers tend to teach as they themselves were taught (Arends in Robertson, 1994, p. II). It is not fruitful or even sensible to draw conclusions based on one example only, but if Nina's directions are any indication of the general state of the current teaching practices, then feminist classrooms are not too far from reality for the future generations.

\section{Literature}

Andersson, K., \& Gullberg, A. (2012). What is science in preschool and what do teachers have to know to empower children? Cultural Studies of Science Education, 9(2), 275-296.

Bignell, K. C. (1996). Building feminist praxis out of feminist pedagogy: the importance of students' perspectives. Women's Studies International Forum, I9(3), 315-325. 
Bristol, T. J. (2015). Teaching boys: towards a theory of gender-relevant pedagogy. Gender and Education, 27(I), 53-68.

Forrest, L., \& Rosenberg, F. (1997). A review of the feminist pedagogy literature: The neglected child of feminist psychology. Applied and Preventive Psychology, 6(4), 179-192.

Freeman, H., \& Jones, A. (1980). For women only? Women's Studies International Quarterly, 3, 429-440.

Gore, J. (1993). The struggle for pedagogies: Critical and feminist discourses as regimes of truth. Routledge.

Haraway, D. (1991). Simians, cyborgs and women: The reinvention of nature. Routledge.

Harding, S. (1986). The science question in feminism. Cornell University Press.

Karlson, I., \& Simonsson, M. A. (2011). Question of gender-sensitive pedagogy: discourses in pedagogical guidelines. Contemporary Issues in Early Childhood, $12(3), 274-283$.

Kavka, M. (2007). Feminism, ethics, and history: What is the "post" in postfeminism? Tulsa Studies in Women's Literature, 2I(I), 29-44.

Lawrence, E. (2016). Feminist pedagogy. Retrieved June 3, 2020, from http:// www.genderandeducation.com/issues/feminist-pedagogy/.

Lusted, D. (1986). Why pedagogy? Screen, 27(5), 2-16.

McKenna, E. (1996). Some reflections concerning feminist pedagogy. Metaphilosophy, 27(1-2), 178-183.

Robertson, L. (1994). Feminist teacher education: Applying feminist pedagogies to the preparation of new teachers. Feminist Teacher, 8(I), II-I5.

Shrewsbury, C. M. (1987). What is feminist pedagogy? Women's Studies Quarterly, IS(3-4), 6-I4.

Thompson, A., \& Gitlin, A. (1995). Creating spaces for reconstructing knowledge in feminist pedagogy. Educational Theory, 45(2), 125-150. 


\title{
What Can We Learn About Feminism from Web Portals? - Analysing Media Bulletins
}

\author{
Mirjana Adamović, Institute for Social Research, Zagreb, Croatia
}

\section{Introduction}

ociety's relationship to feminism and feminist values speaks not only about the level of gender equality achieved but also the level of the democracy achieved and readiness to support the equality of those who believe their rights are being violated and feel like they are not full members of that society. Women, to paraphrase Carole Pateman (1988) are still not, nor ever have been, recognised as equal members or citizens of any known democracy because, even though they have a general right to vote, in public spaces of political or economic importance where decisions of crucial social importance are being made, women continue to not be present or underrepresented despite the best efforts of gender mainstreaming. Moreover, women are marginalised in the public sphere (Harp et al., 2016) as well as marginalised and underrepresented in media discourses and practices (Bachmann, Harp \& Locke, 2018; Byerly \& Ross, 2006). Basically, stereotyping feminism and feminists is inseparable from stereotyping women in general.

The new kind of antifeminism differs from the form which appeared in the 1970 s and 1980 s, despite individual feminist values being incorporated in institutional and social lives, namely "a substitute for feminism" as explained by Angela McRobbie (2009), in the still patriarchal system of economic power and domination, is a new form of the "sexual contract", promising young women that they will achieve equality through education and employment and by participating in the consumer culture and civil society. 


\section{Media, Women and Feminism}

The media is a "major cultural and ideological force standing in a dominant position with respect to the way in which social relations and political problems are defined and the production and transformation of popular ideologies in the audience addressed" (Hall, 1988, p. II8). Institutions such as the family, schools and media produce and reproduce hegemonic ideologies whereby the mainstream media adapt ideologies to "common-sense" attitudes (Vavrus, 2002).

Backmann et al. (2018) believe there are several landmark moments in the history of researching the relationship between women and the media. One of the first is the conclusion reached by the sociologist Gaye Tuchman (1978) that women mostly do not feature in the mediated public sphere or are featured as carriers of stereotypical roles of victims, mothers or incompetents, and that the issues of gender equality as well as women's questions and issues are not of significant interest to the media. She calls this state "'symbolic annihilation' because by watching women's representation in the media children can't conclude anything other than the woman belongs at home" (cf. Lance \& Paschyn, 2018). The following landmark moment was the work of Laura Mulvey (1975) which speaks about "women as the object of the male gaze" in movies, where women are most often featured in a passive role or one unimportant for the screenplay, and mostly serve as the object of erotic desire of both movie characters and the audience (see Albertson, 2018, p. 54). Another landmark moment in media research was the realisation that female identity is not a monolithic construct nor are women a homogeneous group whereby "current approaches addressing the creation and sustaining of oppressive gender ideologies understand that these not only serve patriarchal interests but also racist, classist and heterosexist ones" (cf. Lane \& Paschyn, 20I8, p. 7).

The predominant postfeminist discourse in the media serves as a commentary on the status of feminism, which appears unnecessary because all gender issues are either already solved in legislation or solutions for them are being suggested, that is, individual elements of feminism have become incorporated in political and institutional life while words such as "empowerment" or "choice" have been converted into an individualistic discourse and are in use by the media and popular culture, as well as institutions serving as a substitution for feminism (McRobbie, 2009).

In accepting the postfeminist values, there is a difference between western and post-socialist countries; while in western countries, the media portrayal of politicians through their feminine characteristics has become mainstream, in post-socialist countries with a pronounced national 
discourse, postfeminism is a complex phenomenon allowing women entry to the public sphere but simultaneously insisting on their femininity and all associated patriarchal stereotypes and cultural mythos (Danova, 2006; Lance \& Paschyn, 2018).

The phenomenon of celebrity feminism, whose media protagonists often speak from their individual perspectives (connected to a feeling of injustice in performing their professional or social roles) pointing out racial, gender or economic hierarchies, sexual violence or other significant social problems, encountered strong criticism from female feminist theoreticians with regard to the professions the celebrities perform, i.e. a deep collision with capitalism in which gender inequality is incontrovertible. Hobson (2016) warns that celebrity feminism is completely opposed to authentic feminism, which is less mainstream and less attractive than the interpretation of feminism offered by show business stars. Hobson emphasises that famous feminist brands are only a stepping stone to true feminism, and at the same time very removed from true feminist ideas because by many standards, primarily their lifestyles, they represent precisely what feminism is trying to bring into question. This is, claims Gay (20I4), "rebranded and reclaimed feminism" advocated not only by beautiful, famous and generally irresistible women but also by male feminists whose word has a "broader reach" and echoing message instantly becomes viral in today's Internet world. Andi Zeisler (2016) claims that celebrity feminists such as Beyoncé, Emma Watson, Taylor Swift and others, who are privileged to publicly speak about inequality and have popularised feminism, are the ones accountable for transforming the unpopular "angry, the cynical and man-hating" (Zeisler, 2016, xii) discourse into a hot marketable topic. Nevertheless, celebrity feminism has great media visibility and cultural capital, especially significant in Internet culture which has made collective conversation and greater democratisation possible. This sort of communication is based on short messages with a limited number of characters, which can hardly be rivalled by the academic discourse (Hobson, 2016).

Empirical research points to women being less represented in the printed media than men (such as Jia at al., 2016; Stanley, 20I2; Harp, Loke \& Bachmann, 20II) and that the same trend has been carried over to digital media. Further research shows that the often seemingly objective reporting on female politicians' activities conceals a deceitful media intention to portray them as depoliticised (Vavrus, 2002; Danova, 2006). Female politicians are written about as "beautiful, elegant women, devoted mothers and wives", and their private appearances and lives are more commented on than their public role (cf. Danova, 2006, p. I3I). 
Studies of gender culture in South-East Europe have shown that the media discourse "mirroring all of the social controversies of transition, as an ideological state apparatus - participates in the reproduction of very retrograde patriarchal ideological matrices" (Moranjak-Bamburać, 2006, p. 3I). Obviously, media are an active manufacturer of intolerance, discrimination and prejudice because one of the important results in multi-ethnic societies is the differentiation of an "ethnically ideal woman" and the "woman as portrayed by the media"; while the former is connected to the ethnic, patriarchal ideology, the other is a "guarantee" of masculinity (Moranjak-Bamburać, 2006).

Researchers dealing with the status of feminism and feminists reveal that from the middle 1990 s we can recognise a negative cognitive framework of feminism (Riley, 200I; Buschman \& Lenart, 1996; Callaghan et al., 1991). The study of Sarah Riley (200I) established the decoupling of feminist values from feminism, in addition to a new sexist discourse which she demonstrated with the example of everyday communication. This decoupling of feminist values from feminism has the purpose of minimising social change connected to gender inequality by using liberal rhetoric in five ways: positioning feminists as extremists; minimising the significance of the historical oppression of women; minimising the privilege of men in history and the present; marginalising the voices calling for change; and decoupling feminism from feminists in order to portray feminist values as gender-neutral.

Feminist demonisation in the media has been confirmed by several studies, among which it is important to point out Rhode (1995) and Lind and Salo (2002) (see Jaworska \& Krishnamurthy, 2012). Rhode discovered that the media uses four strategies while reporting on feminists: "demonisation, trivialisation, polarisation, and the focus on the individual rather than social transformation" (cf. Jaworska \& Krishnamurthy, 2012, p. 404). Demonisation is a strategy focusing on feminists linked to radicalism, unsexed characteristics, and a deviant lifestyle. Emphasis on the physical appearance of feminists serves to trivialise the feminists' efforts. Feminists are also antagonistic, polemical and do not fall into the concept of normal women, which is strategy of polarisation. Among other things, this approach, states Rhode, prevents feminist efforts for collective action. Lind and Salo (2002) have come to similar conclusions; feminists are demonised, feminism is primarily a topic within the media framework of arts and politics while women are generally written about in the private sphere. Authors have concluded that feminism is not seen as essential when it comes to solving women's everyday lives (Jaworska \& Krishnamurthy, 2012). In their comprehensive and significant quantitative 
study conducted on large samples of British and German printed materials, Jaworska and Krishnamurthy (2012) conclude that there is a tendency of the feminist movement holding a negative connotation, which is chiefly connected with attributes such as past, obsolete and irrelevant.

\section{Methodology}

The research was conducted on all articles published in 2019 tagged under "feminism" on the five most visited Croatian Internet portals according to the Gemius Audience report:I 24 sata, Dnevnik.hr, RTL.hr, Večernji list.hr and Net.hr. The number of articles collected by this method was $\mathrm{N}=$ I8. Most articles were published by the portal Dnevnik.hr (7), followed by Večernji list.hr (6), Net.hr (2), RTL.hr (2) and 24 sata.hr (I).

The sample articles were recorded, saved and analysed using NVivor 2 software. The data were processed using qualitative analysis, namely thematic analysis using the "six-phase framework" first suggested for thematic analysis by Braun and Clarke (2006) and Clarke and Braun (2013).

The first step of the analysis was initial coding in order to group the content and determine the themes. Text coding was done by a single person - the author of this paper. The number of texts included in the analysis is relatively small and, even though there was some concern that there would be an overlapping of themes (Maguire \& Delahunt, 2017, p. 3356) and inadequate diversification in approaching feminist themes and subthemes, in my opinion, this did not occur during the data analysis, probably due to the different editorial concepts of the analysed portals.

Since Braun and Clarke (2006) distinguish between semantic and latent analysis, we chose the latent approach, which tries to reveal ideas, assumptions and conceptualisations, i.e. to provide deeper analytical insights. This latent analysis was conducted in line with an established theoretical framework that Braun and Clarke call a top-down theoretical thematic analysis (2006, p. 83) and which dictated the formulation of our research questions:

Question I: What kind of content is tagged as "feminism" on the most visited web portals?

Question 2: Can different interpretations of "feminist" and feminism be identified in the media's approach to themes?

Following the identification of themes, in this case, different approaches to feminism, in order to gain an insight into the latent data structure, we constructed a thematic map providing an interpretative framework on who is the main actor in feminism; what kind of feminist 
activities are reported on; how is feminist activity connotated (positive, negative, neutral); in what time is feminist activity taking place (present, past, future); what kind of hierarchal power relationship is present; is there any mention of the social consequences of those feminist activities and does the text explicitly use the word "feminism" or are the feminist activities described without a direct feminist attribute.

\section{Results and Discussion}

The topic of feminism is generally underrepresented in tags. Namely, on the five most visited web portals in 2019, there were only 17 cases when content was tagged as feminist. Even more, two of the articles described a single event, while the other articles were about different content. Even a sample this small revealed that some of the web portals are more dedicated to feminist topics and others less. Definitely standing out is the portal Dnevnik.hr (namely its subsidiary portal "zadovoljna.hr"), which primarily addresses a female audience. The underrepresentation of feminist themes is consistent with findings on the poor representation of gender and gender policies in the media and their stronger focus on ethnic, regional and religious equality, as well as complete tabloidisation which is present in individual former Yugoslav countries (Croatia, Bosnia and Herzegovina, Serbia) (Isanović, 2006). Also, content featuring women as principal actors is mostly presented as fun and funny content while serious content is generally connected with male actors (Milivojević, 2004, according to Isanović, 2006).

The answer to our first research question "What kind of content is tagged as "feminism" on the most visited web portals?" shows that despite the small number of "feminist" articles there are, at the same time, several different themes through which feminism is covered. Initially, the data suggested a very wide spectrum of topics: from body perspectives and female physical appearance to sex appeal, activism (in connection with religion, public space and LGBT issues), discrimination of women, patriarchy, racism, marking of significant dates, and the "successful women" phenomena. A more in-depth analysis showed that we can recognise five frameworks for presenting feminist content.

\section{Feminist Pioneers}

This is a historical and, in some ways, educational perspective in approaching feminism because the readers are educated on the significance of individual actors and activities. Actors are persons who stand out in history by some activity which promoted feminist-related values or by fighting for the rights of women; for example, Billie Jean King (the tennis player) or 
Amelia Earhart (the pilot). These women are pioneers in their professions and achieved exceptional feats in their lives.

The name Billie Jean King is written in history in gold letters. With I29 tournament wins in her career, which includes 39 Grand Slam titles, this legendary American is one of the most successful female tennis players of all time. (FP-I)

Amelia Earhart is the most famous female pilot of all time... the first woman to fly over the Atlantic and to attempt to fly around the globe. $(F P-2)$

The main actors are women and the topic is their success fighting either men or patriarchal norms and how they became synonyms of female empowerment, which is the focus of this feminist theme.

The 55-year-old Riggs challenged Billie to a duel in an effort to prove that female tennis players are inferior to men. He claimed that no woman is strong enough to beat him... To the general amazement of the men and delight of the women, Billie outright defeated Riggs in a tennis match played according to tennis rules for men. $(F P-I)$

The theme is covered from the position of merging the private and public lives of the actors, with an emphasis on the individual hierarchical power relations typical of patriarchy and traditional societies and closely connected with the public and private lives of both women.

Billie was the first prominent sportswoman in history to publicly declare herself a lesbian... The famous tennis player decided to stop hiding her sexual orientation. At that point in history, the truth could have severely damaged her career and family relations. $(F P-I)$

I wanted to come out even sooner, but my parents were homophobic. And besides, people kept telling me that it would mean the end of women's professional tennis. $(F P-I)$

The title of one of the articles makes an unclear and sensationalist reference to feminist content in order to mask an educational item on the feminist successes of individual women. Namely, the hierarchical position of women is emphasised in the title "Women should stay in the bedroom", which evokes the dominant message given to women at that time. Yet is also serves to grab the attention of modern-day readers because it suggests that the article is about female sexuality and their affiliation with the "bedroom", whereby more naive readers are tricked into reading an educational-feminist article. Alongside the topics of patriarchy and traditional values, the problem of women entering male professions also stands out. 
It is interesting that she had already noticed the division in society when professions are concerned, so she was very excited when in the newspapers she would find articles on successful women who excelled in areas that were considered "male-only". She would cut them out and collect them in her notebook. ( $F P-2$ )

The social consequences of the actors' feminist activities are clearly noted; successful entry into male-only professions, LGBT rights activism in the case of Billie Jean King, and the fact that the Croatian pilot Katarina Matanović saw Amelia Earhart as her female role-model in a profession that remains predominantly male even today.

In the end, she became an ardent $L G B T$ rights activist, all the while advocating women's rights with the same passion. She struck a blow to chauvinism which it has never recovered from. $(F P-I)$

Ultimately, she inspired the first Croatian female pilot Katarina Matanovic Kulenovic, who is, in turn, today celebrated in a series of children's picture books such as "Goodnight stories for young girl rebels". ( $F P-2)$

In this sort of approach to presenting media content, the words feminism and feminist are explicitly mentioned in the text.

The renowned New York Times wrote that she did more for women in that tennis match than most feminists do in their entire lives. $(F P-I)$

Even if the real truth about her fate never comes out, there is no doubt that Amelia is a true hero and feminist role model to women around the world. $(F P-2)$

The educational approach affirmatively covers the topic, and covering topics according to discourse belongs to the second-wave of liberal feminism because the topic is approached in a way which does not connect women to the home or family sphere (Lončarević, 201I) but through speaking about their public activity, clearly stressing gender hierarchy, pointing out discrimination and saying how necessary is individualism and the public activity of women in fighting for their rights.

\section{Female Politicians and Feminism}

The framework of writing on the relationship of feminism and female politicians, unlike educational feminism, does not contain almost anything explicitly feminist. Instead, the activities of female politicians are approached from the level of news stories on their daily or commemorative activities which are apparently considered "feminist" enough themselves. It should be pointed out that only one of the collected articles deals with the relationship between politicians and feminism. 
The actor in this framework is the highest politically positioned woman in 2019, the then President of the Republic of Croatia, who before becoming president was a member of the Croatian Democratic Union, a right-wing nationalist party. This framework never underlines what actually constitutes an activity connected to feminism, except for stressing the Fulbright Lifetime Achievement Award the President received for "her remarkable, contributions as a leader, diplomat, and public servant" which is also omitted from the text, as it only mentions how the President was a Fulbright scholar in the early 2000 s when she studied in the USA. Viewed politically, the only thing standing out is her presiding over the Council of Women World Leaders, which is also not mentioned further in the text.

The activities detailed in the text are primarily of a ceremonial or commemorative nature, with a special emphasis on the award being dedicated to the President's "family and homeland", which stresses the emotional and national charge of her statement.

\section{"I'm proud to dedicate this award tonight to my family and my homeland", stated Grabar Kitarovic, a onetime Fulbrightscholar. (FPO-I)}

The emancipatory potential of writing about feminism is reflected in presenting the actor's personal stance, which basically deals with the wider issue of human rights.

\section{Her experience during the scholarship taught her not to fall prey to prejudice and to keep an open mind to new ideas and new cultures. (FPO-I)}

In the conclusion of the article are the words of the politician which finally point to the problem of gender equality, even though there is no mention of patriarchal power relations. They stress that women "are more than victims", so even though the text deals with the present time, the future dimension is hinted at in the vague vision of women as future agents of crucial social changes, which may be interpreted as a kind of evaluation of the vast female potential for social change.

Women are still unequal. Even though we have achieved a lot, the discrimination and abuse of women and girls, as well as denying their rights, remain widespread. This concerns all women, regardless of their background, their age or position in society. But don't view women as only victims... they are a source of strength and change. $(F P O-I)$

From the distribution of social power viewpoint, this framework explicitly mentions gender but still in vague terms given the practice of not

2 Retrieved August 24, 2020, from https:/vijesti.hrt.hr/553512/nagrada-fulbright-kolindi-grabar-kitarovic 
mentioning the problem. The text headline gives no hint of dealing with the fight for women's rights but accentuates the President's statement that she was "a girl on the wrong side of the Iron Curtain", although it is well known that former Yugoslavia never was one of the countries behind the Iron Curtain. This was very broadly discussed in the media, along with comments that she had used a completely inaccurate comparison.

The text also mentions "discrimination and abuse of women and girls, as well as denying their rights", allowing it to be said that feminist values in this framework are being presented in a positive context, or at least mentioned as a problem. The word "feminism" is never explicitly mentioned in the text. It is necessary to note that the former, right-wing president has never publicly declared herself a feminist, on the contrary, she explicitly refused to do so in an interview (Brakus, 2015) so we can conclude that tagging this approach as "feminism" is the result of an editorial or wider interpretation of feminism-supportive statements.

\section{Celebrity Feminism}

The typical actor of celebrity feminism is a star of celebrity culture, most often connected to the media or pop culture, i.e. the world of show business (film, television shows, music etc.). They advocate feminist values in their public activities and often, because of this, their other actions are interpreted through the framework of feminist values. In this framework, we find Meghan Markle, the former American actress who is now the Duchess of Sussex and wife of Prince Harry as well as Emily Ratajkowski, who is a "model, actress and businesswoman" and reportedly "one of the sexiest women in the world". They are the topic of most articles in our sample $(\mathrm{N}=4)$.

This theme focuses on the physical appearance of the actors, for example "she wore her hair naturally curly, and her freckles back then were more pronounced than they are today" or "she posed with unshaven armpits". Special focus is also placed on sexuality because "women are often ashamed of their sexuality". The importance of "personal choice" and individuality is stressed, not only in relation to one's body but also in relation to behaviour patterns and clothing choices. Although it might seem that these choices are trivial and have no bearing the political and social core of feminism, this thematic focus is typically postfeminist.

I'm aware that my impression of what it means to be a woman when I was young was mostly influenced by misogynistic culture. Even more, I'm convinced that it still affects my views on sex appeal. But I don't mind it because that is something I chose myself. Isn't that the essence of feminism - the right to choose? (CF-I) 
Physical attractiveness and charm are pointed out as crucial in achieving success which is portrayed as the seduction of a prince and entering the royal family, as is the case with Meghan Markle.

Her beauty and charm seduced even Prince Harry and she managed to get all the way to the Buckingham Palace. $(\mathrm{CF}-2)$

This thematic framework is not deprived of emphasising the actors' awareness of gender hierarchy and inherent discrimination; on the contrary, it strongly accentuates feminist awareness and activism.

Nine-year-old Meghan participated in the "Nick News" show in 19go, protesting against sexist commercials... Meghan was included after having written a protest letter explaining that it is wrong for the show to be called an educational programme if they're promoting sexism in their commercials. (CF-I)

When I was arrested in Washington during the protest against the Supreme Court nomination of Brett Kavanaugh, a man who spent his life disrespecting women, the new headlines weren't about the protest but about the shirt I was wearing. Even left-wing female commentators, who completely supported my reasons for protesting, were commenting on how I managed to forget to wear a bra under the white shirt I wore with my jeans. ( $C F-2)$

Social implications of feminist values are well mirrored by Ratajkowski's statement: "Give women the opportunity to be whatever they want and learn to accept the differences. Preconceptions be damned!"; because its message is clearly that female power can be expressed and strengthened even through one's relationship with their body. At the core of that relationship, obviously, are individuality and the feeling of personal empowerment.

If I decide to shave my armpits or grow them out, that's up to me. For me, body hair is another opportunity for women to exercise their ability to choose - a choice based on how they want to feel. $(\mathrm{CF}-2)$

However, accepting this kind of feminist exposure did not result in a wider understanding of the readers because the social network comments were mostly focused on the hygiene aspects of women's relationship with their bodies, which derogated Ratajkowski's actions and intentions to the level of triviality.

The comments mostly focused on the photograph published with the essay, which featured Emily Ratajkowski with unshaven armpits. (CF-2)

This thematic framework also superficially stresses the class dimension of the Meghan Markle case: "She grew up in a completely normal 
family in California, her parents were divorced and the lived in average American circumstances". The rapid success following her getting married did not affect her feminist values:

She still talks about the same things, cares about the same issues and tries to promote feminism in every way possible. She was always the girl for change and by marrying she found the ideal platform to continue loudly telling the world what she really thinks. (CF-I)

In this framework, the word feminism is explicitly mentioned. The text's temporal dimension is such that it almost completely deals with the present, that is, the past is mentioned only in connection with the continuity of expressing feminist attitudes. Feminism is discussed affirmatively; it is almost presented as mainstream, something immanent and normal for every woman. It is suggested that the advocates of feminism are bold and self-conscious women.

\section{Feminist Activism}

The theme of feminist activism, unlike other thematic frameworks, presents feminism through much more serious and complex stories, regardless of whether they come from the area of social activism, academic community or culture.

The actors of this thematic framework are women such as Seyran Ates, feminist, human rights activist and a female imam who founded a mosque and says she is fighting against political Islam and patriarchy. Another is the sociologist Sara R. Farris, who wrote the book In the Name of Women's Rights: The Rise of Femonationalism dealing with orientalist theories and theories of gender, race and social reproduction, particularly as they apply to the analysis of migrant women in Europe. Another article featured the news that the activist, actress and producer Jelena Veljača, who had co-organised the "Justice for little girls" protest demanding a system of helping victims of sexual abuse, was a guest on Croatian television. She had commented on the \#MeToo movement and argued with the TV host about the relationship of the producer Harvey Weinstein and actress Salma Hayek after the actress had published a column in The New York Times in which she broke a I 4-year silence and spoke about the nature of Weinstein's sexual demands she had experienced while they were working together.

Under actors, I included feminist authorships or cult achievements such as, for example, the Vienna premiere of an opera composed and directed by women featuring a libretto based on the biographical novel by Virginia Woolf Orlando: A Biography because the said novel questions 
gender norms and is considered one of the first English novels about transgender issues. The title clearly highlights that the opera's title role is played by a transgender person. Here I also included the play I haven't stopped since the morning by the Croatian drama writer Una Vizek, which speaks about the power relations between men and women in the private sphere because in the imaginary matriarchal society women hold all the power, while the men are at home, taking care of the children, doing the laundry and cooking... they haven't stopped since morning.

Given the variety of actors, different hierarchical relationships are mentioned; for example, in the case of the liberal mosque, the issues are gender equality and the acceptance of LGBTIQ identities, the right of women to pray alongside men and asking for the possibility of women to lead in prayer as well as social implications of feminist values.

I've been fighting against so-called political Islam, against patriarchy and traditional structures in my Turkish-Kurdish community since I was Is-years-old - says thisfeminist, whose life was transformed because of her activism. (FA-I)

And while religious freedom is one of the basic human rights, it is not more important than other rights, such as women's rights or sexual rights. And those rights also have to be respected. ( $F A-I)$

This theme further broaches a number of subthemes important to feminism and feminist theory; for example, the literary work of Virginia Woolf touches upon the issue of identity: the novel ... written in a satirical biographical manner, she dedicated to her female lover and long-time friend Vita Sackville-West, an eccentric British poetess. Another theme which was introduced is that of racism, i.e. the reinforcement of nationalist strategies which blame the disempowerment of European workers on migrants and which also serve to strengthen the right-wing options. Further, the subtheme of femonationalism was mentioned, in the sense of neonationalists and neoliberals exploiting feminist ideas. The noted issues are some of the main contemporary political and feminist questions in the European and global contexts.

Racism definitely plays a role in strengthening the right-wing movement by spreading the idea that all our problems are caused by migrants. This is a classic rightwing nationaliststrategy. $(F A-2)$

I view femonationalism as an integral part of the neoliberal reorganisation of the social, labour and state immigration policies within the context of the mentioned financial crisis. It is also an attempt by west European parties to advance their xenophobic politics by advocating for gender equality. It is actually fascinating 
that those parties are using the ideas of women's rights in an effort to lobby against migrants and Muslims. On the other hand, an increasing number of these parties are led by women, for example, Marine Le Pen, which makes them additionally attractive to other women. (FA-2)

You are a white heterosexual male in a position of power. You do not understand that men and women, even when they occupy the same position of power, are not equal. This is what feminism is trying to say for a long time now. ( $F A-3)$

One of the hierarchal relationships being indicated is the one involving individual European feminists (Élisabeth Badinter, Ayaan Hirsi Ali, Oriana Fallaci) joining anti-Islam movements. This is also the only thematic framework dealing with the activist engagement of other feminists and the only one which notes a distinction between feminist activist orientations.

Entire female organisations have turned ... against Muslims by advocating a ban on wearing traditional coverings and portraying Muslim women as passive victims which need to be rescued and emancipated. This anti-Islam feminist front presents sexism as a sole component of Muslim culture and Islam as a dangerous religion which must be stopped. (FA-2)

During the 6os and 7os, there were ideological divisions between Marxist and radical feminists, but at the same time, they all agreed on issues of abortion rights, employment and divorce. All those women came from completely different backgrounds but they were united in their demands. Today feminism remains very divided, especially based on class. $(F A-3)$

This thematic framework speaks affirmatively of feminism and also discusses the status of academic feminism, providing greater insight into the more complex division of feminism, as well as the issue of women accepting male values and positions in corporations.

The so-called academic feminism is a powerful phenomenon dating from the Iggos and early 2000s which has been gaining popularity in the past ten years among younger women and at a global level. The young are especially drawn to the neoliberal feminism... The women of today want to be louder, more visible and successful, and to have more self-confidence. $(F A-3)$

The term feminism is not mentioned in all the articles; for example, it is not referenced in the article about the opera portrayal, but is clearly articulated in all of the other articles. This thematic framework is focused on the present, featuring topics which are significant to diverse contemporary societies. 


\title{
Feminism and Film
}

This thematic framework comments on feminist-themed movies as well as their main protagonists or announces specialised events such as feminist film festivals. Generally, it features film critiques or articles inspired by the feminist actions of movie protagonists. One of them showers such praise on the movie "Legally Blonde" that it even suggests a kind of "feminist know-how" or "guide to life" for young girls which is based on the movie script. Namely, the actors of this thematic framework are movie characters, such as Elle Woods for example.

In the comments of movie portrayals, the hierarchical aspects, i.e. power relations, are relatively emphasised through the retelling of the movie plot.

\section{When she first arrived at Harvard, Elle Woods was seen by everyone as a stereo- typical stupid blonde and made fun of because of her clothing style. (FF-I) \\ One of the landmark scenes in the movie "Legally Blonde" is certainly the one in which professor Callahan invites Elle to his office pretending to want to congratu- late her. He then proceeds to try and convince her to sleep with him if she wants to advance her career. $(F F-I)$}

In the desire for feminist achievements of the movie hero Elle Woods to be transferred into a personal, real-life philosophy, this framework offers numerous pearls of wisdom inspired by the feminist actions of this film character presented as advice, so it can be said that the implications of potentially "feminist activity" are extremely pronounced. The text is primarily entertaining in character and is evidently intended for younger readers.

\author{
If something feels weird, it means it is weird. \\ ... nobody should suffer sexual harassment to succeed. \\ Don't be afraid to take the lead. \\ ... Elle is persistent enough and confident enough to take the lead. \\ Always be the best friend you can be. \\ ... Elle always makes sure that her friends are ok before she even looks at a man... \\ she is the president of her sorority. (FF-I)
}

The word feminism is mostly omitted from this thematic framework and when it is used for the purpose of analysis it is mostly in compound terms such as "the film's feminist framework". In one of the examples, this is elaborated through a string of cultural stereotypes denoting that women are not perceived as carriers of power unless they behave or appear in accordance with codes of hegemonic masculinity. About the example of 
the movie "Terminator: Dark fate", under the title "The irrelevant new Terminator movie: light action for kids with no thrill, fear or mystery but with an unconvincing feminist twist", the following is written:

\section{This type offeminist twist might have worked in the superb last instalment of Mad Max: Fury Road (2015), but it doesn't work here. Even the old grey-haired Sarah can hardly convince anyone that she could endure even Io seconds against the new terminator, much less that she's capable of destroying it like some fierce warrior. $(F F-2)$}

In this thematic framework, the feminist values are contextualised in two ways - affirmatively, as we have already stated, and negatively, like in the following example:

Finally, it all seems like an unconvincing attempt to glorify the vision of gynecocra$c y$, a society where all the power is held by women. $(F F-2)$

\section{Conclusion}

The positioning of feminism on the bulletins of web portals can, from an educational standpoint, seem confusing because on one hand social institutions are increasingly incorporating gender awareness and taking gender parity into account while, on the other, the topic of feminism is sooner marginalised and trivialised than represented, in line with previous scientific knowledge (McRobbie, 2009; Lind \& Salo, 2002; Rhode, 1995; Jaworska \& Krishnamurthy, 2012).

We determined that the articles on feminism fit into one of five thematic frameworks: feminist pioneers, female politicians and feminism, feminist activism, celebrity feminism, and feminism and film. The feminist activism framework holds the greatest educational potential because it mostly presents interviews or statements by feminists of an academic, cultural or activist provenance who are also the main actors of this framework and whose statements authentically broach a series of feminist subthemes ranging from the relationship towards sexual violence, family violence, patriarchal values, LGBT rights, racial rights, migrants etc. Due to the gravity of the approach to the subject, this framework is also the least attractive in terms of following feminism for an audience desiring concise and short messages (Hobson, 2016) but it is also the only framework touching on the ideas of "real feminism" (Gay, 2014). The feminist pioneers thematic framework is oriented to the past and also features an educational intent by introducing the audience to women who have managed to succeed in male-dominated professions. This framework is more built on the idea "see what women can accomplish" than on the ideas of 
feminism, although feminism is mentioned in the framework as well as the public activism of individual actors. The actors of this framework are written about both from the public and the private sphere, sometimes garnished by lascivious headlines.

The thematic framework female politicians and feminism is surprisingly the least educational; namely, there is almost no mention of politics, feminism as a word is not mentioned and the framework does not feature any true political feminist messages. This result is surprising but corresponds to the earlier mentioned theoretical insights of McRobbie (2009) that there is a new form of sexual contract in action because the political framework basically speaks about the educational achievements of the highest-ranking female politician; sending a laconic message to women that education brings equality so that educated women can realise their highest ambitions, including ambitions in high politics.

Certainly, most attractive to young audiences are the thematic frameworks celebrity feminism and feminism and film which are built on famous real or fictional actors. While the former are attractive due to their popularity in show business and their lifestyles, the latter are known to younger audiences from high-budget movies. Celebrity feminism definitely is very significant in spreading feminist values because it broaches an array of important and contemporary themes like female bodies, sexism etc. But at the same time a series of themes crucial for the global or local context such as abortion, reproductive rights etc. does not feature in this framework (Bachmann et al., 2018) nor does it speak about actual marginalised women (Vavrus, 2002). The feminism and film framework is more entertaining in character and features comments upon movies or (non)feminist acts of movie characters. Some of the individual comments in this framework are stereotypical in nature so it remains questionable how much the authors actually understand feminism and from which position their comments are coming.

Despite the limitations of this analysis due to the small sample, we can say that how useful the Internet is for feminism and how feminism is truly perceived by young audiences should be studied by asking them directly. However, it is certain that the entertaining and simplified messages hinting at feminism sent by celebrity feminists will resonate most strongly with young people.

\section{References}

Albertson, W. C. (2018). Sleeping with the Enemy: The Male Gaze and Same-Sex Relationships on Broadcast Network Television. In D. Harp, 


\section{J. Loke, \& I. Bachmann (Eds.), Feminist Approaches to Media Theory} and Research (pp. 53-64). Palgrave Macmillan.

Brakus, A. (2015). Seksizam, mizoginija i bijeg od feminiz-

ma. Na svu sreću, KGK izjavila je kako nije feministkin-

ja. Retrieved July 7, 2020, from https://www.libela.org/

sa-stavom/6338-na-svu-srecu-kgk-izjavila-je-kako-nije-feministkinja/.

Bachmann, I., Harp, D., \& Loke, J. (2018). Through a Feminist

Kaleidoscope: Critiquing Media, Power, and Gender Inequalities. In

D. Harp, J. Loke \& I. Bachmann (Eds.), Feminist Approaches to Media Theory and Research (pp. I-16). Palgrave Macmillan.

Braun, V., \& Clarke, V. (2006). Using thematic analysis in psychology. Qualitative Research in Psychology, 3(2), 77-101.

Buschman, J. K., \& Lenart, S. (1996). “I am not a feminist, but...”: College women, feminism, and negative experiences. Political Psychology, I7(I), 59-75.

Byerly, C. M., \& Ross, K. (2006). Women and Media: A Critical Introduction. Blackwell.

Callaghan, M., Cranmer, C., Rowan, M., Siann, G., \& Wilson, F. (1999). Feminism in Scotland: Self-identification and stereotypes. Gender and Education, $I I(2)$, I6I-I77.

Clarke, V., \& Braun, V. (2013). Teaching thematic analysis: Overcoming challenges and developing strategies for effective learning. The Psychologist, 26(2), 120-I23.

Danova, M. (2006). Women in politics in Bulgarian newspapers: post-feminism in a post-totalitarian society. In N. Moranjak-Bamburać (Ed.), Stereotyping: Representation of Women in Print Media in South East Europe (pp. III-I32). Mediacentar.

Gay, R. (2014). Emma Watson? Jennifer Lawrence? These aren't the feminists you're looking for. Retrieved August 8, 2020, from https://www.theguardian.com/commentisfree/2014/ oct/ro/-sp-jennifer-lawrence-emma-watson-feminists-celebrity.

Hall, S. (1988). The Hard Road to Renewal: Thatcherism and the Crisis of the Left. Verso.

Harp, D., Loke, J., \& Bachmann, I. (2016). The spectacle of politics: Wendy Davis, abortion, and pink shoes in the Texas 'fillybuster'. Journal of Gender Studies, 26(2), 227-239.

Hobson, J. (2016). Celebrity Feminism: More Than a Gateway.

Retrieved July 20, 2020, from http://signsjournal.org/ currents-celebrity-feminism/hobson/. 
Isanović, A. (2006). Media discourse as a male domain: Gender representation in the daily newspapers of Bosnia and Herzegovina, Croatia and Serbia. In Stereotyping: Representation of Women in Print Media in South East Europe (pp. 43-80). Mediacentar.

Jaworska, S., \& Krishnamurthy, R. (2012). On the F word: A corpus-based analysis of the media representation of feminism in British and German press discourse, 1990-2009. Discourse and Society, 23(4), 4OI-43I.

Jia S., Lansdall-Welfare T., Sudhahar S., Carter C., \& Cristianini N. (2016). Women Are Seen More than Heard in Online Newspapers. PLoS $O N E, I I(2)$, eOI 48434 .

Lind, R., \& Salo, C. (2002). The Framing of Feminists and Feminism in News and Public Affairs Programs in U.S. Electronic Media. Journal of Communication 52(I), 21 I-228.

Lance, E. A., \& Paschyn, C. (2018). The Applicability of Symbolic Annihilation in the Middle East. In D. Harp, J. Loke \& I. Bachmann (Eds.), Feminist Approaches to Media Theory and Research (pp. 37-52). Palgrave Macmillan.

Lončarević, K. (2OII). Liberalni feminizam u 20. veku. In I. Milojević \& S. Markov (Eds.), Uvod u rodne teorije (pp. I27-138). Univerzitet u Novom Sadu, Centar za rodne studije.

Maguire, M., \& Delahunt, B. (2017). Doing a Thematic Analysis: A Practical, Step-by-Step Guide for Learning and Teaching Scholars. AISHE-J, 8(3), 335I-335I4.

McRobbie, A. (2009). Gender, Culture and Social Change. SAGE.

Moranjak-Bamburać, N. (2006). The unbearable lightness of stereotypes. In N. Moranjak-Bamburać (Ed.), Stereotyping: Representation of Women in Print Media in South East Europe (pp. 9-42). Mediacentar.

Pateman, C. (1988). Spolni ugovor. Ženska infoteka.

Riley, S. (200I). Maintaining Power: Male Constructions of "Feminists" and "Feminist Values". Feminism \& Psychology, II (I), 55-78.

Stanley, J. (2012). Women's Absence from News Photos: The Role of Tabloid Strategies at Elite and Non-elite Newspapers. Media, Culture \& Society, 34, 979-998.

Vavrus, M. D. (2002). Postfeminist News: Political Women in Media Culture. SUNY Press.

Zeisler, A. (2016). We Were Feminists Once: From Riot Grrrl to CoverGirl, the Buying and Selling of a Political Movement. Public Affairs. 
ŠOLSKO POLJE, LETNIK XXXI, ŠTEVILKA 5-6

\section{Web sources}

https://vijesti.hrt.hr/5535I2/nagrada-fulbright-kolindi-grabar-kitarovic (17. 06. 2020) 


\title{
Feminism and Gender-Neutral Language: Between Systems and Effects
}

\author{
Mojca Šorli, Faculty of Arts, University of Ljubljana, \\ and Institute for Slovenian Literature and Literary Studies ZRC SAZU, \\ Ljubljana, Slovenia
}

\begin{abstract}
As much as a glimpse into the prevailing cultural patterns, within which current gendered social-linguistic bickering takes place, can also contribute to a tolerant and inclusive discussion of "linguistic subversion" (Jogan, 2018).

The power of form /.../ is that very symbolic power that enables power to fully realise itself by concealing itself as power and letting everyone acknowledge it, approve of it, and accept it precisely because it appeared as universal - a universality of mind and morals (Bourdieu, 200I, translation by M. $\check{S}$.).
\end{abstract}

\section{Introduction}

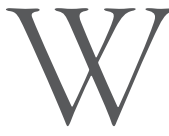

hile the first quote refers to "bickering", as some have labelled the public discussion that took place in 2018 and 2019 about gender-neutral language and how to limit its androcentricity, the second quote answers some key questions about the relation between the symbolic and the universal, on the one hand, and the distribution of social power, on the other. These questions are also central to discrimination in language as part of a wide range of aspects of inequality and social marginalisation of individual groups. The present article and the author's previous work on gender-neutral language in Slovenia are the result of noticing that on the discursive level, especially in less formal discourse, but also in institutionalised discussions about gender and language, the rights of socially disadvantaged groups are all too often disrespected, including 
the right to question culturally assimilated "truths". As a social semiotic and a symbolic code that determines the ways we think about someone or something, language is an important social institution and a key battlefield for equality that must remain open to activist intervention. In terms of gender-neutral language (hereinafter GNL), ${ }^{1}$ it makes more sense to discuss what speakers do with language in social interaction than what constitutes language and its systemic aspects. The conceptualisation of language outside its user is problematic because language is primarily a field of action and social practices. According to Tuldava, discourse, as the most important social aspect of language, is a pragmatic process dealing with meaning (Verdonk, 2002, p. 18; Widdowson, 2004, p. 8) in the sense of interactive events that have meaning and that posit "agency". As such, discourse determines the balance of power between individual participants. Critical discourse analysis (CAD) rejects the assumption about the neutrality of science (Van Dijk, 2008), as scientists are also (or especially) part of social structures that establish important balances of power. This is why (critical) analysis of academic discourse has been central to CAD and other linguistic studies across the world in recent years. For Fairclough (1992, p. 128), a critical linguist, discourse is a special way of constructing the subject matter that includes rules about genres. For Kress (1989, p. 7), discourses are "systematically organised sets of statements which give expression to the meanings and values of an institution" and include a variety of genres. However, it was not until the advent of corpus linguistics, which made it possible to examine large quantities of language data, that true (quantitative and qualitative) discourse analysis became possible. In a narrow linguistic sense, discourse can be understood simply as a type of text that entails identifying conventional patterns of language use. The longest tradition among approaches to gender and language must be recognised in (variational) sociolinguistic analyses (Kranjc, 2019, pp. 396-397), which were based on considerations of language as a product of the individual's personal sociodemographic circumstances. In the following sections, we will observe GNL particularly as it is revealed at the intersection of feminism, linguistics and education. In doing so, we will touch upon various aspects of education, such as teaching materials, language resources and academic discourse about language. The level of the implementation of GNL at the discourse level in a range of educational environments will be examined.

I Initiatives to limit gender disproportion come from many international and supranational institutions. Guidelines and policies for GNL (gender-neutral language, also gender-fair or gender-sensitive language) are an integral part of gender equality policies (UN, UNESCO, European Parliament and others). 


\section{A Brief Overview of the History of GNL in Slovenia and Abroad}

It is important to note that specifically addressing the topic of gender equality began in feminist linguistics and in women's studies of the 1970s, producing the strongest traditions in France and the USA. A ground-breaking work about gender categories in language from this period is Language and Woman's Place by Robin Lakoff from 1975, although the author's binary oppositional conceptualisation of gender and gender difference is obsolete from today's perspective. Another book, Man Made Language by Dale Spender from I980, also gained a lot of attention. The icon of French feminism, Simone de Beauvoir, wrote: "Man is defined as a human being and a woman as a female - whenever she behaves as a human being she is said to imitate the male" (in Moran \& Mooney, 2002, p. 479). Among the younger generation of French feminists who strongly insisted that every representation, be it male or female, is first rooted in language and only then in politics, culture, economy and history are the most prominent theoreticians and philosophers, e.g. Luce Irigaray, Hélène Cixous and the Bolgarian-French semiotician Julija Kristeva, who were particularly concerned with language reform. However, de Beauvoir's quote remains at the centre of the polemical debates that have emerged time and again over the decades, and that are likely to continue, as indicated by recent discussions about language (in)equality in Slovenia and abroad. Certain initiatives that took place in the past (Žagar \& Milharčič Hladnik, 1996; activities of the Ministry of Education, Science and Sport and the Office for Women's Politics; Stabej \& Mihovar Globokar, 1995, see Umek, 2008, p. 59; Government Office for Legislation, 2004/2008/2018; Commission for Women in Science (Šribar), 2010; for an overview of the guidelines to date see Dobrovoljc \& Stabej, 2019), were followed by a period of absence of public debate until the decision of the Senate of the Faculty of Arts of the University of Ljubljana on 25 April 2018 to promote GNL in the faculty's rules and regulations. This discussion generated wide public and media interest and went on for several months. ${ }^{2}$ Interestingly, the part of the discussion concerning linguists - who soon formed two opposing camps - was somewhat overshadowed by social and philosophical reflections on (grammatical) gender. Like two decades earlier, the first camp strongly disapproved of the politically-motivated language intervention, while the second camp saw the need for gender neutralisation of language and discourse as advocated by some proponents (linguists, social scientists and post-structuralists). Furthermore, the second camp argued

2 A round table entitled Gender and L anguage at the Faculty of Arts was held on 23 October 2018, and a discussion entitled Gender and Respect, organised by the Research Centre of the Slovenian Academy of Sciences and Arts, took place on 14 November 2019. 
against the decision intervening in the Slovenian language system; in their view, the intervention could only be about language use and policy. Experts in social sciences and humanities (sociology, philosophy, anthropology, law and others) actively participated in the discussion, confirming the interdisciplinary character of language studies. Among the objections to the initiative of the Senate of the Faculty of Arts that were voiced by people who regard themselves as supporters of gender equality was the exclusion of the transgender group from the (binary) conception of gender; this objection did not, however, come primarily from supporters of transgender-oriented language policy, who apparently understood the discussion mainly as an attempt to denaturalise heteronormative discourse. ${ }^{3}$ Furthermore, the objection to the politics of identity - which presumably characterises the "struggle" for gender equality in language and reinforces discrimination by accepting capitalist liberal ideology and the fragmentation of society instead of eliminating it (e.g. Močnik, 2019; Šribar, 2018; Vuk Godina, 2018) - is based on understanding GNL as a "women's struggle", when in fact it is first and foremost a "social struggle". ${ }^{4}$ This problem is embodied in the "universal" categories of male-centric syntax and the description of, for instance, "human" in a dictionary, indicating a close connection between grammar and social power, especially given the centuries-long tradition of male-as-the-norm. It is often difficult to provide empirical evidence for gender discrimination and male domination in language at the level of its symbolic structures. To understand more broadly the promotion of GNL that can be observed in the post-structuralist (and post-rationalist) approaches to language, it is important both to consider the insights of feminist linguistics and women's studies, as well as the sociolinguistic and sociological perspectives on gender and language, while research is also being conducted on the connections between GNL and gender stereotyping and gender discrimination as part of a broader Marie Curie Initial Training (Language, Cognition, and Gender)' research infrastructure in psycholinguistics.

Helena Drnovšek Zorko: https://www.cep.si/wp-content/uploads/2019/03/Perspectives_DZorko_27.3.2.pdf.

4 Here lies the core problem of the binary conceptualisation of gender: "women's" efforts to achieve equality are first interpreted as a matter of "female identity politics", and only then as a matter that concerns "man" or humanity in general, while for men it is the other way around.

5 http://www.itn-lcg.psy.unibe.ch/content/index_eng.html. 


\section{(Grammatical) Gender as a Category of the Language System}

\section{The (Non-)Neutrality of the Masculine Grammatical Form}

The notion of gender categories in the language system seems very appropriate for illustrating the power that shows itself as universality (Bourdieu, I991, p. 240). It is the existing linguistic norm - i.e. the power that is "recognized by all and thus universal" (ibid.) and seems self-evident, and for this very reason is questioned by the GNL - that justifies the neutrality of the masculine grammatical form. In reality, gender is a complex grammatical category defined on at least four levels: grammatical, lexical or lexical-semantic, referential, and social (gender) (cf. Hellinger \& Bussmann, 200I, pp. 7-II). Here "referential gender" refers to a dynamic referential relation linking linguistic terms to social reality and by no means to a biological characteristic of the referent. Therefore, a (political) choice that critically observes the existing asymmetries in language is quite legitimate. We all actively participate in inclusion or exclusion through our language choices. Which practices are conventional, and how they become conventional, depends on complex social processes, not just in relation to language. As male and female speakers, we differ in the perception of the male grammatical gender as neutral referring to all genders. Slovenian Grammar (Toporišič, 2000), the Slovenian Normative Guide $200 I$ and Slovenian linguistics traditionally state that it is the masculine gender that is neutral in both standard and colloquial language, as well as in dialects. Every language has its own system, which is based on the implicit social agreement. However, "language" is more than just a system. Within the (structural) linguistic-systemic perspective, there is a belief that the problem of gender inequality does not originate in the grammatical gender category and thus cannot be solved by language. Others believe that the problem of GNL must be solved exclusively by the existing linguistic means, i.e. with the linguistic-systemic possibilities of Slovenian. However, the awareness that the neutrality of the masculine grammatical gender not only solves but creates new problems of linguistic hierarchisation has been present for a long time.

\section{"Feminisation" in Language and Society}

"Feminisation" in language, i.e. the use of gendered, or gender-non-neutral, forms (for job titles) in Slovenia dates back to the r990s. In this sense, "feminisation" refers to "the introduction of linguistic feminine forms" with the aim of limiting the androcentricity of language, and, as evident from the source, without conveying any evaluative meaning. This is typical of all field terms (see sense "linguistics" below, $\mathrm{SSKJ}_{2}$ ): 


\section{feminisation}

I. an increasing number of women in places of work or various professions: feminisation of the teaching profession

2. the acquisition of feminine characteristics: feminisation of men was also evident in the way they dressed

- biol. a change of certain characteristics in the male organism to female characteristics; ling. a process by which a word or form changes to the feminine form.

However, by gaining a political profile, the "feminisation of language" has taken on a more negative connotation (the French Academy and conservative linguists are strongly against the "feminisation of French"). By analogy with sense r of "feminisation" above concerning professions and occupations, where, as corpus data show, ${ }^{6}$ feminine forms often acquire a pejorative connotation, such as in tajnica (Eng. secretary) as opposed to tajnik (Eng. secretary), etc., feminine linguistic forms in general hold a non-neutral status through evaluative meaning. Therefore, interventions in traditional nomenclatures and address terms, e.g. gender-specific job titles, do not in themselves bring improvements. As shown by GNL reforms in some languages, they can even be counterproductive, such as forms with a feminine grammatical suffix in French (écrivaine, poetesse) and English (chairwoman, poetess, etc.). The non-neutral, sometimes pejorative meaning of these forms has to do with the way we use language in its evaluative function in the existing power relations. Slovenian is a language with limited possibilities of concealing grammatical gender. However, in languages of this kind as well as in those where it is possible not to express gender (i.e. where syntax is less gender-marked), one can note the dilemma between the decision to "feminise" agent nouns, on the one hand, and to "neutralise" them, on the other. The former makes women more prominent but often carries pejorative connotations, while the latter - using the masculine form as the norm - makes women invisible. For the purpose of this article, however, the first meaning mentioned above is the more interesting one, since empirical data show that it is the most common in standard language and tends to trigger negative evaluation.

6 Lexical and discursive analysis of the use of the lexeme "feminisation" (Šorli, 2020) as an example of a seemingly neutral language - based on the dictionary entry in the Dictionary of Standard Slovenian - reveals strong social connotations and gender asymmetries. The word often appears in contextual environments that portray it as something negative, socially undesirable or as something associated with events, facts or characteristics that encourage negative associations. 


\section{Gender: Language and Society/Culture}

One of the forms of power that increasingly appears as "a universality of mind or morality" (Bourdieu, I99I) is certainly gender being conventionally conceived of in binary terms based on the biological dichotomy between man and woman. However, attributing the "bodily" gender is itself a social decision that has more to do with convention than biology (Fausto-Sterling, 2000, p. 4; Butler, 1993, 1990). For this reason, Perger (2016), for example, uses the term "a person who is socially recognised as a woman/man" in her study of sexism in higher education. Money and some other psychologists use the term "gender" to describe "an identity or self-presentation of a particular individual" (Money \& Ehrhardt, 1972) that is always structured in terms of the demands of society. In contrast, many sociologists (e.g. Lorber, 1994, in Fausto-Sterling, 2000, p. 4) use it to describe a social structure that differentiates between men and women and can drastically interfere with their personal freedom. Fausto-Sterling uses the term "gender" in both of the above meanings and the term "sex" when referring to issues of the body or behaviour: "An individual, therefore, has a sex (male, female, not designated, other); but they engage with the world via a variety of social, gender" and, of course, language conventions. "Gender, then, is definitely in the eye of the beholder. Sex and gender presentation are in the body and mind of the presenter" (ibid., p. 7). Some researchers from the field of social sciences and gender studies have therefore tried to relativise the role of biology. They speak of the social or cultural construct and reject the widespread assumption that gender is based on sex (Antić Gaber, 2014, p. 162). In reality, it is always the social conventions, language or discourse structuring of gender (and sex) that is under discussion, rather than the "natural" characteristics. Feminist (post-structuralist) theory in particular (e.g. Butler, 1990) shows how complex and inherently divided the concept of gender is, proving above all that it is impossible to separate language or the language system from the construction of social reality, which is confirmed by the statement that "every time we speak, our language is the historical effect of language practices, usually controlled by the leading ideology" (Močnik, 2019, p. 357). French post-structuralist theory itself knows different approaches to explaining sex and gender in relation to language. Irigaray, for example, believes in the existence of only masculine sex that "elaborates itself in and through the production of the 'Other"' (in Butler, 2006 [1990], p. 25):

In a move that complicates the discussion further, Luce Irigaray argues that women constitute a paradox, if not a contradiction, within the discourse of identity itself. Women are the "sex" which is not "one." Within 
a language pervasively masculinist, a phallogocentric language, women constitute the unrepresentable. In other words, women represent the sex that cannot be thought, a linguistic absence and opacity. Within a language that rests on univocal signification, the female sex constitutes the unconstrainable and undesignatable (Butler, 2006 [1990], p. I3).

However, Wittig argues "that the category of sex is, under the conditions of compulsory heterosexuality, always feminine (the masculine remaining unmarked and, hence, synonymous with the 'universal')" (Butler, 2006 [1990], p. 25). In the section that more directly discusses relations in language, Butler states that a performative twist of language and/or discourse conceals the fact that "'being' a sex or a gender is fundamentally impossible" (ibid., p. 26). These theoretical considerations offer possible explanations as to why the introduction of the feminine into language (e.g. feminine terms for job titles, social roles, etc., or agents, syntactic agreement with the feminine gender, etc.) often generate new asymmetries, especially in terms of meaning and evaluation.

\section{Discourse and GNL in Education}

The field of education is particularly vulnerable to the transmission and dissemination of ideologies because of the marked "natural" imbalances of power between actors. The final section therefore focuses on the discourse and impact of GNL in education, based on some analyses already conducted and on practices implemented. Pirih Svetina (2012) notes that ideological properties can be attributed to different (linguistic) theories due to their power and influence, which is reflected in language textbooks. Silverstein (1979) argues that linguistic ideology is a "set of beliefs about language articulated by the users as a rationalisation and justification of perceived language structure and use". The historical role of textbooks has changed over the years, but they have always reflected the situation in science and specific philosophical orientations (Čok et al., 1999, pp. 194-198, in Pirih Svetina, 2012, p. 23). Any social ideology is strongly reflected in teaching methods and textbook development, and - of particular importance for GNL - in the transfer of scientific theories into practice and actual (language) use (Pirih Svetina, 2012, p. 23). The problems of gender (in)equality are reflected in at least four basic areas of the pedagogical process that affect the language norm in different ways: gender-sensitive language use in addressing students/pupils, teaching materials, language resources and lexicographic discourse, and (systemic) new stereotyping of social roles through gendered reading lists and other school activities. In the present article, we will only briefly discuss the first 
group, as a great deal has already been said about the problem of the generic use of the masculine gender that significantly influences language use in educational institutions (Gastil, 1990; Bahovec, 1992; Kunst Gnamuš, 1995; Žagar \& Milharčič Hladnik, 1996; Hellinger \& Bussmann, 200I; Hellinger \& Motschenbacher, 2015; Šribar, 2010; Bajić, 2012; Perger, 2016; Kern \& Vičar, 2019, etc.). The role of teaching materials and language resources is also briefly discussed, focusing on the social role of the dictionary, which is remarkably powerful in both language standardisation and GNL.

\section{Gender-Neutral Language in Nomenclatures and Terms of Address}

The origins of GNL in Slovenia and the social climate surrounding it can be traced back to the two-year discussion initiated by European and national authorities (1995-1997) (cf. Umek, 2008, p. 58), which led to a revision of the gendered entries found in the Standard Classification of Occupations (1997). Recent research conducted by Bajić (2012) compared the views and behaviour of Slovenian and Serbian high school students and showed that Slovenian students have a significantly more positive attitude towards this issue than their Serbian counterparts, who have never been exposed to language policies of this kind. Thus, research on the implementation of GNL in Slovenia and Serbia has shown that language policies significantly influence the use and awareness of young speakers (high school students). GNL is considered not only in education, but also in various other areas of public life, such as law (e.g. Štajnpihler Božič, 2019). Although the problem of nomenclatures and naming seems to be the most obvious example, it is in fact one of many levels where gender asymmetry manifests itself. As noted, the most deeply rooted problem arises from gendered address and gendered marking of the symbolic aspects of language. Although expressed in a variety of forms, the latter is equally problematic in many languages (e.g. Hellinger \& Bussman, 20०I).

\section{Teaching Materials}

Another study of GNL in the pedagogical field was conducted by Kranjc (2019, pp. 395-404), who examines pedagogical discourse in language teaching materials on the basis of which students form concepts about gender roles. Kranjc also finds that this is a frequently addressed topic in Slovenia, but that teachers lack adequate guidance on how to increase their sensitivity to GNL. The analysed materials showed that it was rarely possible to avoid stereotypical gender roles intentionally (ibid., pp. 399400). Moreover, many existing Slovenian language teaching materials continue to reflect disproportionate attention devoted to male and female 
authors. Gender-neutral discourse will thus play a crucial role in structuring the fields of literary studies and education in the future, including the reform of the (national) literary canon. These fields may - for now - be free from the imminent threat of "feminisation", but in order to achieve a more gender-balanced representation of literary knowledge they should develop a certain "feminist awareness"; as we know, the creation of gender stereotypes in society is also the result of a ".../ single-sex perception of literature and thus of writing. Such selective exposure to literature can impair adolescents' ability to make critical judgements ... For example, teenage girls are forced to identify with male protagonists, which then carries over into real life ..." (Repar, 2015).

As the representation of women authors in teaching materials is a broad and complex topic, and has therefore been addressed independently, it will not be the focus of the present article (cf. e.g. Mihurko Poniž, 2019; Vendramin, 2018).

\section{Language Resources and Lexicographic Discourse}

Various language resources (dictionaries, grammars, encyclopaedias, etc.) are an important repository of social meaning, although by no means the only one. For example, Gorjanc (2005, 2012, 2017) studied how stereotypes and prejudices about social groups are encoded in Slovenian lexicographic discourse. Dictionaries reflect social values not in the way they are practised, but "on the basis of the current social ideal" (Béjoint, 2000, p. 124, in Gorjanc, 2005, p. 199). In fact, every dictionary is influenced by an ideology, as it reflects social values and introduces the view of the most influential social group in terms of stigmatising and/or discriminating vulnerable groups (e.g. women, homosexuals, immigrants, etc.), which can be indirectly (stereotypes) or directly (insults, swear words) offensive. Furthermore, stereotypes "can lead to offensive references in relation to a particular social group" (Gorjanc, 2005, p. 199), with a focus on women in the present article. While definitions and usage examples can serve to identify explicit and, in particular, covert ideologies (ibid., p. 200), it is this covert nature that is at stake in modern practices of addressing and talking about women, because directly expressing one's ideology or even insulting this particular group is no longer socially acceptable. Gorjanc notes that many directly offensive terms or "negative emotive labels" for women appear in the Dictionary of Standard Slovenian (SSKJ) and even more so in the Slovenian Normative Guide (SP 200I) (e.g. babǐšce (Eng. old bag), gobezdulja (Eng. loudmouth), debeluharica (Eng. fatso)), while also finding some examples of covert sexism (bejba (Eng. chick), etc). The use of these terms is often mislabelled, indicating a lack of social 
responsibility and GNL through the representation of women. Most importantly, these dictionaries do not show actual usage, which can be analysed using contemporary reference corpora (such as Gigafida 2.0 and SIWaC). Thus, the linguistic norm is reflected at the level of the selected dictionary entries, as well as the definitions and usage examples, where the interpretation of reality and the social norm take precedence over grammatical gender. Lexicographic descriptions of meaning and usage play an important role in defining words, such as oseba (Eng. person) or človek (Eng. man/human), in the context of GNL (see especially senses 2 and 4 including examples, below):

člôvek -éka m ed. in dv. (ó ẹ)

1. bitje, ki je sposobno misliti in govoriti: človek in narava; človek se rodi, umrje; te živali se bojijo človeka; anatomija človeka; razlika med človekom in živaljo

2. oseba ne glede na spol ali oseba moškega spola: neki človek stoji pred vrati; ta človek ni priljubljen; našel sem človeka, ki me razume; bližal se je neki bradat, visok človek; pri mizi je prostora še za dva človeka / ekspr. ni ga človeka, ki bi tega ne vedel to vsakdo ve / kot nagovor: človek, kaj pa misliš; ali te ni sram, človek božji / človeka vredno življenje II s prilastkom oseba kot nosilec kake lastnosti: dober človek to rad stori; boj se hinavskega človeka; pameten, pošten človek; star človek tega ne more razumeti / star. popotni človek popotnik / v povedni rabi. čustven, izobražen človek je; saj ni ravno lahkomiseln, slab človek; postal je čisto drug človek

II s prilastkom oseba kot nosilec časovno, krajevno ali kako drugače povezane skupine: mišljenje evropskega,

renesančnega človeka; biti kmečki, mestni človek; slovenski človek / gledališki, poslovni človek / skrb za delovnega človeka

3. ekspr., navadno v povedni rabi kdor združuje $v$ sebi vse pozitivne moralne lastnosti: bodi človek in ne živina; to je človek, to je mož; ni vreden, da se imenuje človek; v vsakem človeku je nekaj človeka

4. nar, s svojilnim zaimkom (zakonski) moż: kje pa je tvoj človek

Picture I: Lexicography at work in gender-(non)neutral language: noun clovek (Eng. human) (Dictionary of Standard Slovenian, second edition $\left(\mathrm{SSKJ}_{2}\right)$ )

A quick look at the lexicographic description of these (lexically and semantically) gender-neutral words may call into question their neutrality in public discourse in which grammatical facts are not considered, where perceptions, intentions and effects of meaning and communication matter more. A dictionary must contain grammatical facts and should convey the actual usage, meaning and pragmatic function of a word in a social context. However, usage examples often reflect the "social reality as seen by lexicographers” (Gorjanc, 2005, p. 205). For comparison, a corresponding dictionary entry from the Oxford-DZS Comprehensive EnglishSlovenian Dictionary (Krek, 2005-6) is shown below to demonstrate attempts of a balanced gender representation policy based on actual usage at the level of entries, definitions and usage examples: 


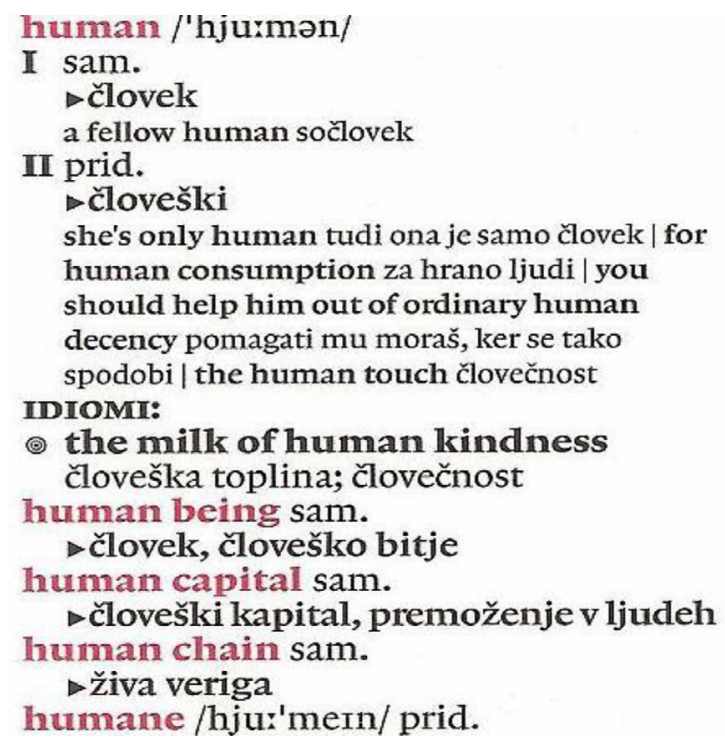

Picture 2: Lexicography at work in gender-(non)neutral language: noun human (The Oxford-DZS Comprehensive English-Slovenian Dictionary)

The systematic definition of feminine agent nouns as derivatives of masculine nouns is another aspect of male-centric language that has been common in foreign language practice (e.g. Béjoint, 2000, pp.133-134, in Gorjanc, 20I2, p. 206). There are 786 instances of the definition "feminine form of" in SSKJ (e.g. asistentka (Eng. teaching assistant), docentka (Eng. assistant professor), državljanka (Eng. (female) citizen), the examples of which are all too often stereotypical or even morally and ethically controversial in the face of social reality. Gorjanc (ibid.) cites, among others, an example with the label "expressive" in "he will beat her black and blue"? In summary, lexicographic discourse has the power to promote or combat harmful ideologies such as sexism, homophobia, racism or anti-immigrant sentiments.

\section{New Stereotyping or Re-Traditionalisation of Social Roles}

In light of what has been said, it is all the more surprising that the practice of entrenching gender roles and stereotypes has expanded in recent decades. One example may be the increasing tendency to separate "books for girls" from "books for boys", as found on reading lists in schools. This trend can be seen equally well in public libraries, where books are divided into "blue" and "pink/red" categories, as found in some young adult 
sections of public libraries. More importantly, this practice is implemented by institutions that, along with schools, have absolute authority over the reading culture of children and young adults, and seems to contradict the goals of promoting gender equality in everyday life (social, professional and economic equality). This reproduces gender stereotypes - especially in terms of evaluative meaning, such as in "the feminisation of education, society, etc." - that perpetuate social inequalities both conceptually and at the level of linguistic expression.

\section{Conclusion}

More in the form of an epilogue than a section proper, the latter theme has highlighted daily experiences that, when evaluated in the context of current social, political and cultural realities, can mean only one thing: regression in the prospects of gender equality and the erosion of already established standards of emancipation. To pursue the goals of equality and resist the erosion of emancipatory practices, different and sometimes diametrically opposed social approaches coded in language use and in teaching materials should be adopted. Solidifying traditional gender roles and gender stereotypes in educational processes counteracts the efforts to make female literary authors more prominent compared to their male counterparts. Moreover, it does not increase sensitivity to issues of social inequality in general or make young girls and boys more aware of physical, psychological and economic violence against the vulnerable, nor does it empower young people to become socially critical individuals. However, language remains a key factor in either achieving or undermining social equality, which is why this issue was given prominence in the present article. The most socially influential groups tend to deny others the right to challenge what is culturally taken for granted in discussions about language and gender. The debate surrounding GNL is clearly less about the language system and more about communicative processes and their social implications. Therefore, the focus is first on language as public discourse: language use is embedded in much broader social (im)balances, with gender construction taking place through and primarily in language. At the same time, the notion of language system cannot be completely bypassed in any debate about language policies, as the levels of language functioning are complex and interdependent. Some typical discourses involving "feminisation" can be identified on the basis of corpus analysis of the relevant contexts, in particular the conception of women's dominance as a deviation from the norm and male dominance as (supposed) neutrality. This discursive phenomenon is analogous to the supposed neutrality of the grammatical norm whereby (male) grammatical gender is 
believed to be immune to the asymmetries found in common social relations. Empirical - i.e. corpus-based - research shows that "feminisation" denotes the process of women "taking over" in many spheres of public life, and is typically associated with negative evaluation. There is a strong perception in society that women increasingly dominate certain areas such as education, law, journalism and health care, and even the military, which is seen as a social problem. As for the discourse analysis of discussions on GNL (e.g. Šorli, 2019; Mikić \& Kalin Golob, 2019), it is worth noting that arguments opposing efforts to reduce male-centric language come from different and even opposing ideological positions, indicating the complex nature of societal perspectives that determine whether GNL would be supported or opposed. However, what really connects the different findings in gender-related theories is symbolic power, which is presented as a universal despite being simply power, which is also discussed by Bourdieu (1991). Another expression similar to many other feminine grammatical forms in that it is devoid of content is "feminine writing" (the French term écriture féminine being a rare exception to the rule), which is mostly used pejoratively to "discredit female writers as 'peculiar' or 'particular' in relation to the 'universal' or supposedly 'gender unmarked' writing of men." This struggle is similar to that taking place in linguistics. Slovenian female author and translator Barbara Simoniti sums it up with the following thought: "I have never heard anyone say that 'William Shakespeare was one of the greatest representatives of male world literature.' Literature is universal - or at least it wants to be. However, it is fascinating that this universal feeling disappears almost instantly when a text is written by a woman."

\section{References}

Antić Gaber, M. (20I4). Biološki/družbeni spol ali kako misliti razmerja socialnega, kulturnega in biološkega. In A. Fausto-Sterling. Biološki/ družbeni spol: biologija v družbi. Krtina.

Bahovec, E. (1992). O feminizmu in psihoanalizi: onstran problema poimenovanja. Problemi-Eseji, 30(I-2), I3I-136.

Bajić, N. (20I2). Spolno (ne)občutljiva raba jezika v Srbiji in Sloveniji v teoriji in praksi. In Ideologija v slovenskem jeziku, literaturi in kulturi, (A collection of articles Seminar slovenskega jezika, literature in kulture, 48) (pp. 124-128). Znanstvena založba Filozofske fakultete.

Béjoint, H. (2000). Modern Lexicography. An Introduction. (Ist edition 1994). Oxford University Press.

8 http://www.cityofwomen.org/sites/default/files/VsakDan8Marec_Slovenscina.pdf 
Bourdieu, P. (1991). Language and Symbolic Power. Polity Press.

Bourdieu, P. (200I). Masculine Domination. Stanford University Press.

Butler, J. (2006 [1990]). Gender Trouble. Feminism and the Subversion of Identity, Routledge.

City of Women (Mesto žensk). http://www.cityofwomen.org/sites/default/ files/VsakDan8Marec_Slovenscina_i.pdf.

Connell, R. (2012). Moškosti. Krtina.

Čok, L., Skela, J., Kogoj, B., \& Razdevšek-Pučko, C. (1999). Učenje in poučevanje tujega jezika:smernice za učitelje $v$ drugem triletju osnovne šle. Pedagoška fakulteta, Znanstveno-raziskovalno središče Republike Slovenije.

Dobrovoljc, H., \& Stabej, M. (2019). Jezikovne izbire v slovenskih smernicah za spolno občutljivo rabo jezika. Slavistična revija, 67(2), 373-384.

Fairclough, N. (1992). Discourse and Social Change. Polity.

Fausto-Sterling, A. (2012). Sex/Gender. Biology in a Social World. Routledge.

Gastil, J. (1990). Generic pronouns and sexist language: The oxymoronic character of masculine generics. Sex Roles, 23, 629-643.

Gilbert, Scott F., 2010: Developmental Biology. Sinauer Associates.

Godina Vuk, V. (2018). Kako globoko so padli tovarišice in tovariši humanisti na FF. Fokuspokus (13. 6. 2018). Retrieved October, I0, 2019, from https://fokuspokus.si/article/3III?=kako-globoko-so-padli-tovarisice-in-tovarisi-humanisti-na-ff.

Gorjanc, V. (2005). Neposredno in posredno žaljiv govor v jezikovnih priročnikih: diskurz slovarjev slovenskega jezika. Družboslovne razprave, 21 (48), 197-209.

Gorjanc, V. (2012). Ideologija heteronormativnosti, prevodna in jezikovna norma. In Ideologija v slovenskem jeziku, literaturi in kulturi (A collection of articles Seminar slovenskega jezika, literature in kulture, 48) (pp. 38-44.). Znanstvena založba Filozofske fakultete.

Gorjanc, V. (2017). Nije rečnik za seljaka. Biblioteka XX vek.

Hellinger, M., \& Bussmann, H. (Eds.) (200I). Gender across languages: the linguistic representation of women and men. John Benjamins.

Hellinger, M., \& Motschenbacher, H. (Eds.) (2015). Gender across languages: the linguistic representation of women and men 4 . John Benjamins.

Jogan, M. (20I8). Izključevanje žensk iz ustvarjanja razumskosti. Dnevnik (18. 8. 2018). Retrieved October I, 2019, from https://www.dnevnik.si/ı042836602/slovenija/ izkljucevanje-zensk-iz-ustvarjanja-razumskosti. 
Kern, B., \& Vičar, B. (2019). Jezik in transspolne identitete. Slavistična revija, $67(2), 413-422$.

Kranjc, S. (2019). Spolno občutljiva raba jezika v učnih gradivih. Slavistična revija, $67(2), 395-404$.

Kress, G. (1989). Linguistic Processes and Sociocultural Practice. Oxford University Press.

Kunst Gnamuš, O. (1994/95). Razmerje med spolom kot potezo reference in spolom kot slovnično kategorijo. Jezik in slovstvo, 4o(7), 255-262.

Lakoff, R. (1975). Language and Woman's Place. Harper \& Row.

Lorber, J. (1994). Paradoxes of Gender. Yale University Press.

Mihurko Poniž, K. (2019). Pravljice starejših slovenskih pisateljic v literarni tradiciji in vzgojno-izobraževalnem sistemu. Jezik in slovstvo, 64(2), 5-I8, II5.

Mikić, J., \& Kalin Golob, M. (2019). (Ne)strpno o spolu: primerjava angleških in slovenskih argumentov proti uvajanju sprememb v seksistični rabi jezika. Slovenščina 2.o: Empirične, Aplikativne in Interdisciplinarne Raziskave, 7(2). 75-117. https://doi.org/10.4312/ slo2.0.2019.2.75-117.

Močnik, R. (2019). Identitetna politika na univerzi. Slavistična revija, 67(2), 355-360.

Money, J., \& Erhardt, A. A. (1972). Man and Woman, Boy and Girl. Johns Hopkins University Press.

Moran, D., \& Mooney, T. (2002). The Phenomenology Reader. Psychology Press.

Nomotehnične smernice (2008). Ljubljana: Uradni list. [Publisher: Služba Vlade Republike Slovenije za zakonodajo].

Okrogla miza Jezik in spol na FF UL 23. 10. 2018. Retrieved October I, 2019, from https://www.youtube.com/watch?v=3DhQQzpoHzA.

Perger, N. (2016). Simbolno nasilje spolnega zaznamovanja v jeziku in prakse upora v visokošolskem prostoru. Družboslovne razprave, 32(8I), 4I-60.

Pirih Svetina, N. (2017). Film, ki mladini »dviga kri« ali kaj je ideološkega v praksi poučevanju jezikov? In Ideologija $v$ slovenskem jeziku, literaturi in kulturi (A collection of articles Seminar slovenskega jezika, literature in kulture, 48) (pp. 2I-28). Znanstvena založba Filozofske fakultete.

Posvet Spol in spostovanje: strategije kultiviranja razlik. The SAZU and FF UL organisations, November 2019, the Great Hall in SAZU. Retrieved April 4, 2020, from http://www.sazu.si/uploads/files/57eereobc2337II 44545f64b/Spol\%2oin\%2ospostovanje_Povzetki.pdf. 
Repar, S. (2015). https://www.rtvslo.si/kultura/drugo/v-ucnih-nacrtih-premalo-slovenskih-avtoric-in-ljudskega-izrocila/368689.

Silverstein, M. (1979). Language structure and linguistic ideology. In R. Cline, W. Hanks \& C. Hofbauer (Eds.), The Elements: A Parasession on Linguistic Units and Levels (pp. 193-247). Chicago Linguistic Society.

Slovar slovenskega knjižnega jezika (SSKJ), I97o-I99I. SAZU, ZRC SAZU and DZS.

Slovenski pravopis (SP). Slovar 200I (2003). CD-ROM. Založba ZRC.

Spender, D. (1980). Man made language. Routledge. Retrieved April 4, 2020, from https://www.marxists.org/reference/subject/philosophy/ works/ot/spender.htm.

Šorli, M. (2019). Spol in jezik na robu pameti: Med slovnico in ideologijo. Slovenščina 2.o. Empirične, aplikativne in interdisciplinarne raziskave, 7(2), 45-74. https://doi.org/10.4312/slo2.0.2019.2.

Šribar, R. (20I8). (Ne)odgovorna znanost: svoboda dela in verjetje v režim. Dialogi, ı. Retrieved October I, 2019, from http://www.aristej.si/slo/ PDF/Dialogi\%2010\%2018\%20Uvod.pdf.

Šribar, R. (2010). Interne smernice za spolno občutljivo rabo jezika. Retrieved December 22, 2020 from http://crtomirkosmrl.xyz/download/9ulrMwEACAAJ-interne-smernice-za-spolno-obcutljivo-rabo-jezika.

Štajnpihler Božič, T. (2019). Spolno občutljiva raba jezika v predpisih. Posvet Spol in spoštovanje: strategije kultiviranja razlik. The SAZU and FF UL organisations, November 2019, the Great Hall in SAZU.

The Oxford-DZS Comprehensive English-Slovenian Dictionary (Ed. S. Krek) (2005-6). DZS.

Toporišič, J. (2000 [1976]). Slovenska slovnica. Založba Obzorja.

Tuldava, J. (1998). Probleme und Methoden der quantitativ-systemischen Lexicologie [1987 in Russian source]. Wissenschaftlicher Verlag.

Umek, N. (2008). Feminizacija v slovenščini in francoščini: družbeni in/ali jezikovni problem? Diplomsko delo. FDV and FF.

Van Dijk, T. A. (2008). Discourse and power. Palgrave Macmillan.

Vendramin, V. (2020). Nekaj epistemoloških zapiskov o raziskovanju spola v edukaciji. In I. Ž. Žagar \& A. Mlekuž (Eds.), Raziskovanje v vzgoji in izobraževanju: mednarodni vidiki vzgoje in izobraževanja (pp. 22I-228.). Pedagoški inštitut, https://www.pei.si/ISBN/978-96I-270324-o.pdf.

Verdonk, P. (2002). Stylistics. Oxford University Press. 
Widdowson, H. (2004). Text, Context, Pretext. Critical Issues in Discourse Analysis. Blackwell.

Wittig, M. (2000). Eseji. ŠKUC.

Žagar, I. Ž., \& Milharčič Hladnik, M. (1996). Nekaj izhodiščnih prizadevanj za odpravo seksistične rabe jezika. In L. Bogovič \& Z. Skušek (Eds.), Spol: Ž. KUD France Prešeren: Institutum Studiorum Humanitatis - ISH. 


\section{Sporty Boys and Fashion Girls: Manoeuvring Between Dominant Norms of Gender Identity ${ }^{\mathrm{I}}$}

Majda Hrženjak, Peace Institute, Ljubljana, Slovenia

\section{Introduction}

S

ocial processes such as globalisation, mobility, labour flexibilisation, shrinking of the welfare systems, changes in the structure and dynamics of the family, and the unpredictability of life courses establish modernity as "risk society" (Beck, 1992) or the "age of uncertainty" (Baumann, 2007) and add to the loosening of the sense of community belonging and the fragmentation and individualisation of society. A fragmented society poses new challenges for the construction of gender identities and the attitude to broader society belongings, such as gender, ethnicity or class. Numerous theorisations reveal how the category of gender is deployed and changed also by the neoliberal ideology and how gender binarism is seemingly reformulated through mass media and the market.

Young women are often held to be key beneficiaries of a range of socio-economic changes that now characterise Western societies while the neoliberal discourse of freedom, choice and individual empowerment are increasingly associated with the category "young women". Girls as a category are in neoliberalism positioned as a new social and economic force in ways previously the reserve of boys. Therefore, successful femininity now involves living a tension between exercising the traditional feminine mode of relationality, physical attractiveness and beauty ideals

I This research work was conducted as part of the Masculinities, Equality, Care Practices (J6-8253) project and the Equality and Human Rights in Times of Global Governance ( $\left.\mathrm{P}_{5}-\mathrm{O} 413\right)$ research programme, both financed by the Slovenian Research Agency. 
and the exhibition of achieved gender equality expressed in individualised agency, freedom and choice previously associated with masculinity (McRobbie, 1991; Gonick, 2004). They must be "bright and beautiful", a "heterofeminine/desirable and successful learner", an "aggressor and nurturer" (Ringrose, 2007, p. 485).

Simultaneously, the discourse of the "crisis of masculinity" poses boys as a "problem", as victims and deprivileged compared to girls (Martino et al., 2009). "The boys' crisis" is believed to be the result of the assertion of feminism and gender equality, and hence the changes in gender roles in society, which are said to be leading to the rising identity insecurity of men/boys, their "softening" and "feminisation". This is believed to be particularly shown in the school environment, which is allegedly feminised, due to which boys are said to lack a "real male" role model. The solution for this allegedly increasing feminisation of boys is looked for in the return to the gender norms of traditional masculinity (Beasley, 2005, p. 180). At the same time, neoliberal consumerism addresses boys in a similar way as girls, i.e. with aestheticisation of masculinity underpinned by the advertising cosmetic and fashion industries. According to Mort (in Haywood \& Mac an Ghaill, 2007, p. 163), these images are based on the narcissistic display of macho representations of male power and virility through outfit and style. This corroborates the trends of aestheticisation, the consumer practices and pluralisation of masculinity which are celebrated by some as "the new forms of inclusive masculinities" (Anderson, 2009), while others warn against the hybridisation and promulgation of hegemonic masculinity so as to adapt to the neoliberal conditions (Bridges and Pascoe, 20I4), which only conceal the existing unequal gender relations.

What should also be pointed out is the growing social emancipation, visibility and recognisability of non-binary gender identities that show an impact by way of loosening perceptions of the gender system as natural, heteronormative, stable and complementary.

This makes young people face several ambivalent situations in the processes of their gender identity construction and negotiation. It seems that in an atomised and fragmented neoliberal society, secure and stable self-identity no longer automatically arises from one's position in the social structure, and in its place, some argue that we are seeing attempts to ground identity in the body as individuals are left alone to establish and maintain values with which to live and make sense of their daily lives. Bodies represent ever more important arenas for the complex formation of gendered identities and power relations, among others using 
"techniques of the self" such as self-care, consumption and leisure, involving practices of grooming, dressing, shaping and decorating bodies. Many studies reveal how diverse masculinities and femininities are currently articulated through consumerism that is written onto the body (Bordo, 1993).

Amid the cacophony of ambivalent representations and meanings of modern masculinities and femininities which young people face, it seems interesting that on the level of the construction of gender identities through body/style young people are continuing to be surprisingly gender-traditional. This was evidenced in interviews with 38 teenagers of both genders aged 13 and $14,{ }^{2}$ the largest share of whom, when asked: "What in your opinion is most typical of boys and what of girls?", unambiguously expressed the view that girls typically dedicate much of their time and energy to their outfit, shopping for clothes, and to fashion, while boys do not pay so much attention to their looks, and are more focused on sports, particularly football. What we thus obtain is the "Lévi-Straussian mythical formula" - girls: boys = fashion : football, which schematically expresses the (traditional) symbolic relations and gender differences as well as differences within each of the two gender groups as constructed by teenagers. The article attempts to analyse the symbolic meanings and empirical effects of this equation on teenagers' engendering. The teenagers' responses corroborate the relational, binary, heteronormative and performative vision of the gender system, in which the conduct of gender-specific body practices plays a constitutive role in the construction of gender identities and relations. The analysis addresses the question of the role of clothing practices in establishing gender identities and identity negotiations and conflicts in young people. I specifically highlight the role played by clothing practices in the construction of masculinity and femininity, while also paying attention to the intersections of gender, class and ethnicity. I analyse the role of clothing practices in constructing gender identities as either dominant or marginalised, traditional or alternative, in both the relationship between boys and girls as well as within groups of boys and girls.

2 Thirty-eight individual semi-structured interviews with eighth-graders in the schools in Slovenian cities and towns of Ljubljana, Koper, Maribor, and Trbovlje were conducted within the Stamina project - Formation of Non-violent Behaviour in School and Leisure Time among Young Adults from Violent Families (Daphne programme). The recruiting of children for the interviews with the consent of their parents was based on a selection made on the basis of preliminary quantitative interviews. Qualitative interviews took place in the school environment, lasted 40 minutes to 2 hours, and were recorded and transcribed. Questions referred to family life, school, spare time and friends, intimate relationships, self-perception, experiences with ethnicity and migrations, attitudes about gender and experiences with violence and bullying. 


\section{Gender and Clothing Practices}

Within culturological studies, authors mainly place fashion within the study of youth-subcultural styles (Hall and Jefferson, 1975). Youth subcultures are defined as "attempts to resolve collectively experienced problems resulting from contradictions in the social structure" (Barker, 2000, p. 323). Analyses focus on subcultures of working-class boys, reducing the specific youth subculture to class subculture. Defining style as rebellion, culturological analysis of youth subcultures highlights the positive, creative and political role of clothing practices in identity negotiations of young people, who establish their sense and meaning of a specific style in social criticism and the creation of alternative identity moduses as well as the social locations of their performance. Style in youth subcultures is defined as opposed to fashion, seen as part of the dominant culture, implying subordination and adaptability.

While culturological studies of youth subcultures address styles and their role in young people, feminist theory distrustfully and critically deals with the meaning of outfit and fashion in the construction of femininity. These analyses articulate "the system of fashion and beauty" as "uniforms of patriarchal fantasy" (Thornham, 2000, p. 147) that establish woman as the consumer subjected to male desire, disciplining woman's body through dominant fashion standards (Bartky, 1988), strengthening stereotypical images of femininity and producing repressive norms of the "real" femininity. These analyses reveal a negative and restrictive role of clothing and other related body practices which they define as the mechanism for discipline, control and adaptation to the existing power relations. Although this discourse also partly allows for the ambivalent nature of fashion as both a creative and oppressive practice, it puts significantly more emphasis on its negative, restrictive and disciplining function serving to submit women to the existing power relations rather than to social criticism, and leading to the stereotypisation, shrinking and homogenisation of alternative identities and social locations rather than their creation.

Both theorisations are shown as relevant, but deficient in addressing the engendering of young people through body practices. Their deficiencies may be summarised as follows: I) by focusing on style as rebellion, culturological analysis of youth subcultures ignores the gender dimension and the pressure from the processes of the construction of gender identities in adolescence; 2) by focusing on fashion as the disciplining of femininity under patriarchal and consumerist norms, the feminist critique of fashion omits masculinity from the analysis and the fact that men are also 
gendered beings subjected to disciplining discourses and gendering practices related to body practices; and 3) both approaches omit heterogeneity within their categories (young, women) and the effects of intersected social locations (ethnicity and class) on gendered identity constructions. I continue by analysing clothing practices as a marker of engendering in girls and boys at the intersection of both theoretical approaches, but from the aspect of the listed deficiencies of the two approaches.

\section{Regulated Body and Techniques of the Self}

When asked, what is most typical of boys and girls, teenagers answered:

Blaž (m, aged I 4): "Well, boys don't use make-up, and they don't have so many clothes as girls do. Girls use make-up, they have different clothes, they don't do the same sports as boys, or boys don't do those, where girls are."

Katja (f, aged I4) says: "Boys don't like shopping, that's first and foremost. Hmm, then they don't feel so strongly about their looks, they don't spend over an hour in the bathroom every morning, I guess. Hmm, but there are exceptions that I know of, and who spend on their looks and all."

Tine (m, aged I4) thinks: "Yes, we're more into bikes or such. Don't know, we do, say, football, which I think girls don't do so much, but also. Girls dress more fashionably than boys or such. They care about their weight, figure, yes. That's it, I guess."

These answers show that teenagers of both genders construct gender difference by referring to "typically feminine" (fashion, taking care of how they look) and "typically masculine" (sports, ignorance of outfit) activities related to the body. Body and looks are shown as an important medium of the production of gendered subjectivity, and different body practices represent the ways and means of identity negotiations, conformity or transgression. Foucault (1991) provided an insight into the "regulated body", for which the dominant discourses inscribe gendered norms, also through the clothing rules and caring for one's looks, which work through feminine and masculine subjectivities. A subject's (self)regulation of their own body while striving for conformity or resistance to the dominant gender norms may be understood as a mechanism for constructing the subject as a male or female. From this aspect, the "techniques of the self" (ibid.), such as engaging in sports in the case of the interviewed boys, or taking care of their outfit in the case of the interviewed girls, can be understood as practices of the normalisation of adolescent gender identity into the normative masculinity and femininity. What happens here is a shift from the natural, biological body as the central mechanism of the naturalisation of sexual difference to the discursive body, suggesting that engendered bodies are produced through discursive norms and power relations 
which are invested in and practised on the otherwise unstable, fragmented and changeable body. What remains unexplained in Foucauldian analyses, as pointed out by Bahovec (2002, p. I84), is sexual difference, that is, the question of why women's bodies are more subjected to cultural norms and ideals than men's, why women are symbolically represented as beings that are more exposed to the gaze of the other, and more burdened by the "need" to take considerable care for their outfits. The answer may be sought in the different ways of the disciplining of masculinity and femininity that take place through gender-specific practices of the regulation of girls' and boys' bodies, producing different attitudes to the body and its aestheticisation. I continue by comparing boys and girls in their attitude to clothing practices to disprove the belief that boys, as opposed to girls, are not under the pressure of being disciplined into the dominant models of masculinity also through body practices, and to show that their disciplining takes place through techniques of the self that are different than in girls.

\section{Hegemonic and Subordinated Masculinities}

The last decades have seen growing interest in research into masculinities, which in gender studies has led to a sensible broadening of the focus from an exclusive orientation to analyses of femininity to the study of the relational dynamics between genders and the heterogeneity within the categories of masculinity and femininity. Connell (20I2) derives from the heterogeneity of the category of men, from multiple masculinities, and says that in every moment different models of masculinity are in the mutual relationships of tension and competitiveness, but only one group of men takes the dominant position of hegemonic masculinity. This group is dominant both in its relation to women and to different modes of masculinity. Although Conell defines the hegemonic masculinity as contextual and relational, that is, as changeable, she points to some central attributes or mechanisms of establishing the hegemonic masculinity that are relatively stable in different contexts. On the relational level, these include radical otherness in relation to femininity, namely, the constant endeavours of men to emphasise and constantly demonstrate their difference from femininity, and normative heterosexuality or homophobia. The inclusion of homophobia as an integral part of hegemonic masculinity establishes gay masculinity as a priori excluded from male hegemony. The body is also an integral part of hegemonic masculinity and, according to Connell (ibid.), in Western culture the sign of hegemonic masculinity is a tall, muscular body. The lack of any of these highlighted features can place 
a boy or man in a subordinate relationship to their peers who possess these characteristics.

The concept of hegemonic masculinity sheds light on the identity challenges of boys who in the sensitive teenage period must construct and demonstrate their gender identity in the "right" way. They have to avoid everything normatively constructed as "girlish" (like an interest in fashion, take care of one's looks), and at the same time to nurture the "masculine looks" of a firm, tough and muscular body that establishes and asserts itself in team collective sports as shown by studies of young boys (Frosh et al., 2002), especially football. Research shows that peer pressure exerts basic social control by constructing boys who conform to the dominant gender norms as popular, and those who transgress these norms as subordinate. The answers of teenage boys and girls, when asked which boys are the most popular at school and why, show how hegemonic masculinity is defined in peer culture. Our study, as well as some other studies (ibid.), give very similar answers in this segment. Boys largely agreed that the most popular among their schoolmates are those who express rebelliousness, opposition to school discipline and disdain for study achievements, excellence in sports, especially football, while contributing to this are also body size and figure along with a clothing style that expresses toughness, nonchalance and rebelliousness. The price that is paid by the subordinate boys, for example, those who prefer to associate with girls or stand out in terms of their bodies for their small size, weight or other special characteristics of the body, who do not like football but prefer conversation, who take care of their looks in an inappropriate way, such as wearing make-up instead of doing sports, is exclusion from the peer group, derision, sometimes physical violence. Studies conducted in English schools show that boys' peer group often punishes the schoolmate who deviates from the dominant norms of masculinity through verbal and psychological violence so that their peers make fun of them that he is gay or a girl (ibid., p. 76). This on one hand represents the feminisation of boys who deviate from the dominant norms of masculinity, with which the peer group establishes the "normal" boyness as opposed to girliness. In this way, femininity is established as radical and inferior "otherness" of masculinity. At the same time, these are homophobic practices that strengthen "normal" boyness through normative heterosexuality. The effect of such derision is twofold: the exclusion of the boy who transgresses the norms of hegemonic masculinity too obviously and the strengthening of the existing gender norms for those who do not transgress them. The space for alternative ways that would not be caught up in gender binarism is thus closed (Hrženjak, 20II). The concept of hegemonic masculinity thereby points 
to the processes of the construction of male gender identity as markedly subjected to normativity and performativity, which require teenagers to evidently put themselves in a relationship and comparison with the norm. Because the majority of boys and men do not meet the ideal of hegemonic masculinity, but nonetheless compare with it and are also constantly controlled by the peer group, the pressure of disciplining is constant.

In the aforementioned British study (Frosh et al., 2002, p. II6), the boys were asked what they liked in girls and what kind of girl they would choose to be their partner. Most of them glorified the girls' "difference" from boys, and constructed them as more serious, capable of making a conversation, being good students etc. As the essential criterion for a potentially more intimate relationship, the boys put forward the girl's feminine' looks and outfit. Although they also pointed out that they can have a good relationship with girls with more boyish looks, talk to them and even let them play football with them, they would not "date" such a girl. This can be explained by the choice and looks of their partner for some boys being in the function of confirming their heterosexuality among their peers. The expressed feminine looks of the girl who occupies the position of the boy's partner, which the girl achieves with the adequate sexualisation of her looks through her outfit, confirms and strengthens the boy's heterosexuality, while a partner with more boyish looks might imply his homosexuality. Thus, what in feminism is interpreted as male domination over the spectacle function of the sexualisation of women's dressing is shown as the dispositive of subordination of boys to the heterosexual norm of hegemonic masculinity and peer pressure. Therefore, external looks and outfit are important for the processes of constructing "normal" male gender identity and for the peer identity negotiation in two ways. First, through the aestheticisation of one's looks - the more the outfit will express toughness, sportiness, physical strength and rebellion against the dominant values of the school culture, such as tidiness, decency, orderliness, good behaviour, subordination etc., the more it will correspond to the norms of hegemonic masculinity; and further on with the sexual choice, that is, the looks of their female partner that must be adequately feminine and sexualised to confirm the heterosexuality of the boy, which is the constitutive norm of hegemonic masculinity. The apparent absence

3 It needs to be pointed out that what is presented here is a very schematic and stereotypical, and accordingly exaggerated, outline of certain segments of the processes of teenagers' engendering that refer to taking care of one's looks. The engendering processes outlined in this article affect some teenagers more than others, some are subjected to them, while others consciously decide to deploy different ways of engendering or are faced with different challenges. In fact, given the assumption that a specific outfit is important for establishing of gender identities, it would be especially interesting to make research into just the opposite strategies: 
of boys' care for their looks paradoxically conceals the fundamental care for their appearance which must unambiguously demonstrate the absence of taking care for one's looks, because this is the distinguishing feature that establishes boys not only as different to but as the opposite of girls. The seeming contempt for the feminised practice of care for looks establishes a distance to everything feminine, which represents the basic norm of hegemonic masculinity. This reveals the gap between the actual living practices of young people and the symbolic norms with which they construct gender difference as binary and irreconcilable.

\section{Intersections of Gender, Ethnicity and Class}

The concept of hegemonic masculinity offers insight into the plurality of men, hierarchy and the positions of power established between men and stemming from their diverse positions in relation to hegemonic masculinity. The second dimension of differentiation is determined by social location or multiple belongings according to ethnicity and class. Both dimensions show mutual overlapping and coeffects. In the continuation, I analyse the position of ethnicised masculinity in relation to the hegemonic norm through the example of clothing practice. Gender is the fundamental, but not isolated category, and along with gender teenagers also "adopt" ethnic and class identity positions. These intersections do not represent processes in which certain a priori existing inherent differences between ethnic groups would automatically produce different types of masculinity and femininity. It is more that processes of the ethnicisation and production of the ethnic "other" a priori exist in society, making the images and discourses of "cultural difference" become intertwined and invested in how masculinity and femininity are performed and experienced. Constructions of cultural differences are important elements of social contexts, in which different ways of masculinity and femininity occur, and this, in turn, establishes ethnicity and class as coeffective dimensions of the generation of masculinity and femininity (Hrženjak, 20II). For example, Haywood and Mac an Ghaill (2007) analyse the complex investments of British working-class teenagers in the adoption of the style of the racialised youth subculture. They define them as an example of how boys use race and ethnicity as a cultural source for establishing teenage male subjectivity, with the racialised coloured "other" representing the central position in relation to which the dynamics of the formation of a white boy's identity takes place. A more detailed illustration was given by Phoenix (2004) in her analysis of the Afro-Caribbean boys who

gender identity constructions that are seemingly indifferent to one's looks and the gendered meaning of clothing systems. 
in British public schools are linked with the image of hyper-masculinity, which is related to the effects of racial stereotypes about black people and their sexuality. Therefore, the assumptions about young black boys were "already there", and these boys are appreciated and admired by their peers due to their apparent hyper- and heterosexuality, rebellious style and audacity. As black and poor immigrants, they are on one hand marginalised and subordinate in the school culture and wider British society, while on the other they are appreciated and admired within the teenage peer culture because they appear "manly", rebellious and they resist the school disciplining. The demonstration of masculinity in the form of hypersexuality, the rebellious style and risky behaviour thus becomes a strategy for reducing their existing social marginalisation and represents the minimum space of power that enables boys from deprivileged ethnic and class positions to acquire a peer status that brings respect.

This interpretive framework can be used in the analysis of ethnicised teenagers in Slovenia and the popularity among them of the "famous" blue tracksuit with a white stripe down the side that some years ago marked the "balkanised masculinity". Interviews show that the immigrants of the first and second generation from former Yugoslavia are not marginalised and excluded among their Slovenian peers, as would be expected, but the opposite; they are popular as the carriers of the "čefur culture" which is expressed in a specific style of clothing, behaving, talking and music. Our interviews show that some boys of the majority and dominant Slovenian ethnicity strive to achieve this specific style of clothing, behaving and talking, which may be explained by the ethnicised and culturalised way of popular boyishness or masculinity. Immigrants from the countries of former Yugoslavia are balkanised and ethnicised as well as constructed as dominant patriarchal men, leisurely, careless, witty, good and passionate football players and popular among girls. Compared to their peers belonging to the ethnic majority, also in Slovenia immigrant teenagers are often economically disadvantaged and at the same time marginalised in broader society, outside their peer group, because they belong to the ethnicised minority. Their great motivation to invest energy in playing football can be understood not only as enjoyment in the game and sports but also as an investment in football as a symbol of the hegemonic masculinity, power and reputation that arises from this position. Therefore, immigrant boys are constructed as conforming to the norms of hegemonic masculinity and as having certain qualities that establish them as popular among peers of both genders. But what is important is that these are not empirical characteristics, but the way members of the dominant ethnicity themselves can ethnicise and construct the immigrant "other" in relation 
to the norms of hegemonic masculinity. This image posteriori influences the behaviour, actions and identity processes of both the immigrant teenagers and those from the dominant culture. For the latter, the imitation of the clothing practices (the tracksuit), style, behaviour and even the linguistic accent represents the strategy of engendering through the "readymade" symbolic elements of ethnicised masculinity that are the closest possible approximation of the specifically contextual normative image of hegemonic masculinity. The tracksuit in this context is a sign indicating the position of hegemonic masculinity at the intersection of ethnicity, gender and class.

\section{Normative and Alternative Models of Femininity}

McRobbie (2009) in her analysis of the embeddedness of modern teenage girls in the mechanisms of "consumer citizenship" and "postfeminist masquerade" examines modern normative modes of femininity, placing them in the "new sexual contract", which behind the apparent emancipation of women establishes new structures of their subordination to modern capitalism. "Fashion girls" construct their femininity under the influence of the dictate of cosmetic and fashion industries that through the postfeminist discourse of advertising and mass media establish girls as empowered and emancipated to take control over their lives as a result of the consumerist "empowerment" and "freedom" of individual consumer choice. Interviews with the eighth-grade girls corroborate the vast presence of this model of girliness and can be perceived in girls' admiration of fashion icons, either famous singers or models. If boys, when asked who they would like to resemble and why, generally answered with the name of a famous sportsman, evoking his sports skills and achievements, girls typically gave the names of famous singers and models due to their looks and outfit.

The construction of the category of popular girls that points to the implicit norms of femininity in relation to which girls must generate their girliness is ambivalent. On one hand, popular girls are defined as those who are popular mainly among teachers at school because they follow the dominant values of the school culture, such as good behaviour, achievement, responsibility, social skills, diligence, orderliness etc. One could say these features symbolically define the traditional image of femininity as subordinate, disciplined and passive, in binary opposition to the masculinised features of rebelliousness, lack of discipline and active attitude. On the other hand, girls who were also defined as popular, or rather, dominant by teenagers, were girls who dressed "conspicuously", with the "conspicuous" dressing being defined as a sexualised dressing by both boys 
and girls. When asked why certain individual girls are popular, one interviewed girl responded: "Because, well, hmm, she just, hm, has bigger boobs, and wears her trousers so tight, right, and her T-shirts with a very low neckline. While I don't like wearing just any low neckline T-shirt that makes everything pop out". In defining this group of girls as popular, both boys and girls seemed to construct masculinity and femininity as consistently symmetric and in mutual opposition and complementarity, as corroborated by two British studies (Frosh et al., 2002; Gleeson \& Frith, 2004). The sexualisation of girls' looks corresponds with the logic of intimate-partner choices in boys, which is dictated by the norm of heterosexuality. In their interviews with 12- to 16-year-old girls in the United Kingdom, Gleeson and Frith (2004, pp. 104-III) reveal the characteristics of the sexualisation of the clothing practices in girls. Some girls avoid pink colour because they construct it as the colour that represents a specific type of femininity - passive, innocent, immature and asexual. They see the rejection of pink as a way of creating a distance from the traditional normative femininity; they choose to use black as the testing and identity negotiation of alternative models of femininity. Their refusal of pink as a colour thus shows ambiguity: on one hand, as the tendency to recognise their sexual maturity and at the same time creating a distance from the traditional norms of femininity. Certain pieces of clothing, such as corsets, short skirts, high-heel shoes that also in wider society are constructed as sexualised and believed to stereotypically mark a specific type of female sexuality, are used by girls consciously and intentionally on certain occasions while going out in the evening and associating with friends. The visibility of the body, in particular of certain body parts and the skin, has always been the object of social control and regulation, while simultaneously exposing the body and disclosing its specific parts are one of the dominant norms of femininity. While social norms dictate that our bodies should be decently covered, at the same time they, ambivalently, encourage teenage girls and young women in particular to disclose certain parts through specific clothing styles. The respondents say that part of the pleasure related to sexualised clothing style stems from the wish to attract the heterosexual male gaze, while at the same time they were positive that they do not do this consciously and on purpose. Instead, they naturalise this strategy of sexualisation by saying: "I really like this style", and thus seemingly ignore the meaning that a particular style or piece of clothing has. They also thus ignore the fact that style and clothes have meanings independent of those ascribed to them by the person who wears them. In this way, girls evade the dominant cultural interpretations of their clothing style and insist on the ambivalence and constant identity negotiations between 
the self-representation and the gender norm. On one hand, girls thus seem to be self-disciplined and self-regulated in accordance with male desire or the need of boys for peer confirmation of their heterosexual masculinity, while on the other girls' sexualisation represents a source of their identity explorations, negotiations, ambiguities, and sometimes transgressions as well as resistance to the dominant gender norms.

McRobbie (1991) researched the sexualisation of the outfits of teenage girls from the aspect of the intersection of gender and class. She analysed the subculture of femininity practised by working-class girls in England in the 1970 s and 1980 s, where the sexualisation of outfit represented one of the major elements in the context of fashion, beauty, romance and pop culture. McRobbie interprets this seemingly conservative and traditional girls' focus on pop culture, looks and romance in the context of their transition from girlhood to womanhood, to their budding sexuality and the period of learning of adult sex roles. And while the school curriculum defines sexuality as a matter of biology, and school culture and families treat teenage girls as asexual beings, pop culture, fashion and beauty are attractive to girls for their serious treatment of teenage sexuality. McRobbie hence defines girl's subculture of looks, romance and pop culture as a rebellion against asexual images of adolescence and femininity, as the confrontation with one's gender and sexual identity, and the related insecurities, challenges and expectations. School culture avoids all this by naturalising gender the identities, sexuality and lifestyles of the middle class.

McRobbie does not define the girly culture of looks, romance and pop culture merely as a technique of the self that leads to the (self)disciplining of girls, but sees it as an ambivalent intermediary in the conflictual relationship between the pressures to conform with the dominant gender norms and looking for one's own identity in girls' identity negotiations in the transitional period of adolescence. In this interpretive framework, taking care for one's looks and specific clothing practices can be a source of empowerment, autonomy, and deviance from the dominant norms of femininity. This may be illustrated by Eva's story. In the interview, Eva (aged 13) reported that she had not been getting along with her parents, among other reasons due to their religious beliefs they had expected her to reconcile her clothing style with Islamic customs. Eva belongs to the gothic subculture: she wears exclusively black colour and conspicuous makeup. As she says, she is excluded for her looks also by her schoolmates of both genders because they perceive her as "other" and different. But, despite her conflict with both her parents and peers, Eva persists in her style. Even more, she says it is in her persisting with her clothing style that she 
finds her firmness and self-confidence to resist on one hand the pressures of her parents to conform to the traditional norms of femininity typical of Islamic culture (which would still establish her as "other" among peers) and the dominant norms of femininity, into which the peer culture tries to normalise her (which would then maintain her as "other" in the family environment). In the conflicted relationship between conformity to gender norms of either the family or the peer environment, Eva tries to negotiate her image of femininity with her unique subcultural clothing style.

\section{Conclusion}

Building on the conception of gender identity as unstable, dynamic, relational and performative, and at the same time extremely normatively burdened, the article has analysed teenagers' narratives of self-perception and the meaning of looks and clothing practices from three aspects: from the aspect of the pressures arising from the conflictual processes and negotiations in the construction of gender identities in adolescence; from the aspect of the role held by clothing practices for the engendering of boys and girls; and from the aspect of heterogeneity within the categories of boys and girls, and the effect of the intersecting social locations (ethnicity and class) on gendered identity constructions. Through the concept of hegemonic and subordinate masculinities, boys were revealed to establish a distance from femininity and homosexuality via self-regulation of their body and clothing practices in the context of peer social control to construct themselves as "real" men. An intersectional perspective was used to understand the hypersexualised and hegemonic body practices in boys who are deprivileged in terms of ethnicity and class, for whom the doing of "real" masculinity helps compensate for social marginalisation; while these practices simultaneously become the model for the formation of hegemonic masculinity in some boys of the dominant culture. Further, girls' clothing practices show the relational dynamics between the norms of masculinity and femininity: on one hand, girls are self-disciplined through sexualised clothing practices that correspond to boys' need to obtain peer confirmation of their heterosexuality; and girls can also use this practice as a source of identity exploration and transgression of the dominant gender norms. This especially applies to subcultural clothing practices that may represent a way of resisting the traditional cultural norms of femininity and postfeminist fashion consumerism, and at the same time provide a space for establishing alternative modes of femininity.

Despite the modern conditions of the fragmentation and individualisation of society, neoliberal rhetorics of "free choice" and the postfeminist discourse of gender equality according to which "all battles have been 
already won" (Gill, 2014), our analysis shows that masculinity and femininity exist only in relation to each other and continue to be constructed through normative everyday discourses and practices, which strongly reflect traditional gender relations. In developing their identities, children draw on culturally available resources in their immediate social networks and society as a whole, with the school environment as a powerful transmitter of gender norms. These resources are strongly gendered with males and females receiving different messages, being constrained differently and having access to different codes. To avoid reinforcing the traditional gender dichotomy and power relations, but also to support children in less rigid, more plural and inclusive identity formations, the school should instead of favouring the existing gender norms systematically enable the expression of alternative ways of doing masculinity and femininity by encouraging the understanding of how gender stereotypes, in coeffect with class and ethnic ascriptions, influence their self-image, self-esteem and the experiencing of their peers. This includes positive recognition of non-binary and non-heteronormative gender identities and a critical reflection of the dominant gender representations passed on by the profit-oriented mass media, popular culture, fashion, advertising and sports industries.

The question arises whether traditional approaches to education that aim to maintain the status quo, reinforcing the current power structures and pursuing pupils' competitiveness that employs fear and shame to motivate their growth, are able to support these processes. As an alternative or at least a complement to traditional educational approaches, feminist pedagogy (Shrewsbury, 1987) with its principle that educators seek to empower students by offering opportunities for critical thinking, self-analysis, and the development of voice, appears to be a viable approach for accomplishing that goal. By democratising the classroom situation, feminist pedagogical approaches create space for dialogue that reflects the multiple voices and realities of the students, discussing the students' own experiences and finding commonalities that individuals thought were only personal matters of their own lives. Encouraging students' agency, both personal and political, brings them to realise their own personal stereotypes that stem from race, class and any other background characteristics. It develops, in joint reflection with students, complex accounts of personal and social reality by questioning the notion of a coherent social subject or essential identity, articulating the multifaceted and shifting nature of identities and oppressions. The critical skills fostered by use of a feminist pedagogical framework encourage recognition and active resistance to societal oppressions. Fostering feminist pedagogical principles can strengthen the school in its function of being a safe and open space in which children and 
young people are allowed to openly speak about their experiences with structural marginalisations. In this vein, the school could and should become the ally of young people while looking for the alternative, egalitarian and solidary lifestyles and social developments needed by modernity.

\section{Literature}

Anderson, E. (2009). Inclusive Masculinity: The Changing Nature of Masculinities. Routledge.

Bahovec Dolar, E. (2002). With your brain and my looks. Telo v kulturnih študijah. In A. Debeljak, P. Stankovič, G. Tomc \& M. Velikonja (Eds.), Cooltura. Uvod v kulturne študije (pp. 175-194). Študentska založba.

Bartky Lee, S. (1988). Foucault, Femininity, and the Modernization of Patriarchal Power. In I. Diamond \& L. Quinby (Eds.), Feminist and Foucault Reflections on Resistance (pp. 6I-87). Northeaster University Press.

Barker, C. (2000). Cultural Studies. Theory and Practice. Sage.

Bauman, Z. (2007). Liquid Time. Living in an Age of Uncertainty. Polity Press.

Beck, U. (1992). Risk Society. Sage Publications.

Bordo, S. (1993). Unbearable Weight: Feminism, Western Culture, and the Body. University of California Press.

Bridges, T., \& Pascoe, C. J. (2OI4). Hybrid Masculinities: New Directions in the Sociology of Men and Masculinities. Sociology Compass, 8(3), $246-258$.

Connell, R. (2012). Moškosti. Krtina.

Foucault, M. (1991). Subjekt in oblast. Zakaj preučevati oblast: vprašanje subjekta. In M. Dolar (Ed.), Vednost-oblast-subjekt (pp. 103-I20). Krtina.

Frosh, S., Phoenix, A., \& Pattman, R. (2002). Young Masculinities. Palgrave Macmillan.

Gleeson, K., \& Frith, H. (2004). Pretty in Pink: Young Women Presenting Mature Sexual Identities. In A. Harris (Ed.), All about the Girls.

Culture, Power, and Identity (pp. I03-II5). Routledge.

Gill, R. (2014). Unspeakable Inequalities: Post Feminism, Entrepreneurial Subjectivity, and Repudiation of Sexism among Cultural Workers. Social Politics: International Studies in Gender, State and Society, 2I(4), $509-528$.

Gonic, M. (2004). The Mean Girl Crisis: Problematizing Representations of Girls Friendships. Feminism \& Psychology, I4(3), 395-400. 
Hall, S., \& Jefferson, T. (1975). Resistance through Rituals. Youth Subcultures in Post-War Britain. Routledge.

Haywood, C., \& Mac an Ghaill, M. (2007). Men and Masculinities, Open University Press.

Hrženjak, M. (20II). Vrstniško nasilje v perspektivi dominantnih konstrukcij ženskosti in moškosti ter sovpadanja strukturnih neenakosti. Šolsko polje, 22(3-4), I3I-I 47 .

Martino, W., Kehler, M., \& Weaver-Hightower, B. M. (Eds.) (2009). The Problem with Boy's Education. Beyond the Backlash. Routledge.

McRobbie, A. (1991). Feminism and Youth Culture. Palgrave Macmillan.

McRobbie, A. (2009). The Aftermath of Feminism. Gender, Culture and Social Change. Sage.

Phoenix, A. (2004). Neoliberalism and Masculinity: Racialization and the Contradictions of Schooling for II to I4-Year-Olds. Youth \& Society, 36, 227-246.

Ringrose, J. (2007). Successful Girls? Complicating Post-Feminist, Neoliberal Discourses of Educational Achievement and Gender Equality. Gender and Education, Ig (4), 47I-489.

Shrewsbury, C. M. (1987). What Is Feminist Pedagogy? Women's Studies Quarterly, I5 (3-4), 6-I4.

Thornham, S. (2000). Feminist Theory and Cultural Studies. Stories of Unsettled Relations. Arnold.

Zaslow, E. (2009). Feminism, Inc. Coming of Age in Girl Power Media Culture. Palgrave Macmillan. 



\section{The Grammar of Knowledge: A Look at Feminism and Feminist Epistemologies}

Valerija Vendramin, Educational Research Institute, Ljubljana, Slovenia

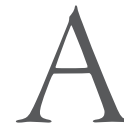

$s$ a postscript and by way of a response to all the contributors in this issue of The School Field, I would like to "wrap up" all of the subjects presented into a single general theme: feminist epistemologies. Better still: this may be seen as some sort of conversation I wish I once had, but have not (perhaps an opportunity for a roundtable on this topic will arise some day). At the same time, I wish to thank the authors all for their cooperation and, after all, for opening up new intellectual spaces and reflecting on those already in place. The theme of teaching feminism is important, even more so in the present times, as is obvious from all of the issues raised and dealt with by the authors in this issue. But let me first start with feminism. Feminism is many things to many people, says Helen Longino, "but it is at its core in part about the expansion of human potentiality" (Longino, 1987, p. 60; see also Vendramin, 2018, p. 75).

At this point, let me briefly deal with the singular/plural issue raised by the title of this text, i.e.: feminist epistemology vs. epistemologies (FE). FE is an approach to epistemology (rather than a single school or theory) that uses gender as a central category. Gender is indeed a central category, but - as a sort of contribution to more precise thinking - other axes of discrimination and marginalisation are included. According to Marianne Janack (n.d.): feminist epistemology “identifies how dominant conceptions and practices of knowledge attribution, acquisition, and justification disadvantage women and other subordinated groups, and strives to reform them to serve the interests of these groups". Phyllis Rooney says that "feminist epistemology (as encompassing a range of epistemological projects informed and linked by efforts to uncover the political and 
epistemological fallout of the epistemic disenfranchisement of women and other 'others') proceeds in fruitful conversation with a range of approaches or directions in epistemology, and it is unique in this kind of epistemological flexibility" (Rooney, 2010, p. 21).

This explains why feminist epistemology can sometimes also be spoken about in the plural (Janack, n.d.). ${ }^{\mathrm{I}}$ Feminist epistemologies contain an important feature that sets them apart from other traditions (to which they are indebted in various ways and extents) - the emphasis on the epistemic salience of gender and the use of gender as an analytical category in discussions, criticisms and reconstructions of epistemic practices, norms and ideals (ibid.).

Phyllis Rooney (20II, pp. 5-6) in this regard deals with another important issue, namely with the "persistent refrain in mainstream epistemology circles that feminist epistemology is not epistemology 'proper,' and thus not something with which epistemologists need concern themselves". This attitude "has ranged from hostile to dismissive to limited acknowledgement" (ibid). These dismissals, ${ }^{2}$ writes Rooney, "are problematic for epistemological as well as political reasons /... and/ are quite revealing of unexamined assumptions about epistemology 'proper"' (ibid., p. 6). Hence, not only is a gendered subject marginalised in a research study or inquiry, but the very discipline dealing with being a gendered knowing subject (and all the categories that go along with it, such as objectivity, justification, reason etc.) and researching the consequences of this is also marginalised.

This epistemological theme appears in many articles here, sometimes explicitly, sometimes less so. But it is there in different ways. As Nina Lykke puts it: rather than homogenising, it is important to provide a heterogeneous feminist space for comparing notes (Lykke, 20IO, p. 135). ${ }^{3}$ And, as she continues:

My claim is that this particular thinking technology may make more visible current feminist commitments to rethinkings of bodily and transcorporeal materialities, and to the unfolding of innovative kinds of knowledge producing practices which transgress both positivism, social

Feminist philosophers "have articulated three main approaches to this question - feminist standpoint theory, feminist postmodernism, and feminist empiricism" (Janack, n.d.). These three approaches are given here for information only, they often converge and no doubt have developed over time.

2 There is talk about political correctness and agendas - about something that allegedly has no place in science. For a little more on the "criticism" of feminist epistemology, see e.g. Vendramin, 2009. 
constructionism, and post-modern relativism and anti-foundationalism. A strong commitment to ethics - and a belief in an inextricable link between epistemology, ontology, and ethics - is also a common denominator of the diversity of heterogeneous theories /.../ (ibid.).

Accordingly, these strands of thought lead us to dealing with the taken-for-granted, which can be expanded in various directions, one of them being meanings acquired in everyday life. ${ }^{4}$

But, in connection to delineation of what feminist epistemology (or epistemologies) is, Elizabeth Anderson, for example, warns as following:

Feminist epistemology has often been understood as the study of feminine "ways of knowing." But feminist epistemology is better understood as the branch of naturalized, social epistemology that studies the various influences of norms and conceptions of gender and gendered interests and experiences on the production of knowledge (Anderson, 1995, p. 50).

This quite general presentation (general in the sense that I chose it, not because Elizabeth Anderson's thinking is too general in defining it) can be complemented, for instance, with Iris Van der Tuin's definition (2016):

Feminist epistemology refers to the feminist engagement with questions of truth, objectivity, method, and the knowing subject. /.../ The key question of feminist epistemology as a field of inquiry involves the epistemic status of the knowledge produced by privileged and marginalized subjects. Where to draw the line between knowledge and prejudice? In sum, feminist epistemology pertains to the intersection of knowledge and power.

This last sentence is particularly important here, as knowledge is always someone's knowledge (and by "someone" in this case I mean a particular social group). Wherever there is significant social stratification, there are likely to be epistemic effects (Grasswick, 200I, p. xv) - i.e. an influence on the concepts of knowledge, inquiry, justification and the like.

A famous phrase by Donna Haraway goes like this: "Vision is always a question of the power to see" (Haraway, 1991, p. 192), and so the assertion made by the researcher that she or he watches from everywhere and sees everything, that she or he has no desires, needs, convictions or backgrounds, is contentious (Haraway, 1991, p. 192) and an evasion of

To briefly return to the sphere of education, this especially concerns both the curriculum and the hidden curriculum. Particular attention should be paid here to the hidden curriculum because a certain level of doubt and reconsideration is required in order to detect and analyse it (see e.g. Bahovec \& Bregar-Golobič, 2004). 
responsible discourse (my italics). This is a view from a position that is transcendent, which means that I/we/someone is speaking (better: claims to be speaking) above the level of human activity, above politics and power - and beyond lived experience.

In contrast with more traditional definitions of objectivity, feminist objectivity is achieved not through transcendence - this would be the "god-trick" (done by the allegedly disembodied scientist, which is a traditional positivist view of science) of being the Deity in relation to the rest of the universe (Haraway, 1991, p. I83 ff). ${ }^{5}$ It is done through a dynamic engagement with partial perspectives stemming from marginalised positions. We should not forget the ethical and moral implications here, i.e. the challenge and responsibility to recognise power relations. Iris Van der Tuin describes it in this way: "one of the most important methodological innovations of feminism has been the distinction between 'studying up' and 'studying down'. Studying down implies that asymmetrical power relations are reconfirmed easily in research. The alternative, studying up, is the standpoint theoretical model of researching from the lives of marginalized subjects" (Van der Tuin, 2016).

As already mentioned, feminist epistemology is not research into some kind of easily and generally detectable gender-specific, i.e. feminine, ways of knowing, styles of thinking, intuitions, methodologies and ontologies that govern or characterise cognitive activities (Anderson, 1995, p. 62; Vendramin, 2018) - at least this is my understanding. As Phyllis Rooney states:

The idea of "women's/feminine ways of knowing" has indeed surfaced in feminist epistemology, but the primary focus has been on how problematic the idea is. Among other things, it involves generalizations about women (across different races, classes, and cultures, for example) that have been the focus of significant critical scrutiny in the past three decades of feminist theorizing (Rooney, 2010, pp. 6-7).

Such understanding avoids dubious claims about feminine cognitive differences and enables feminist research in various disciplines to pose deep internal criticism of mainstream research (Anderson, 1995, p.

Haraway's text entitled "Situated Knowledges: The Science Question in Feminism and the Privilege of Partial Perspective" from Haraway, 1991, is one of the most important texts on epistemological issues (I do not wish to say "in feminism" here, because it should be discussed wider). See above about feminist epistemology and "epistemology proper". Haraway points out that feminists are interested in science projects "that offer a more adequate, richer, better account of a world, in order to live in it well and in critical, reflexive relation to our own as well as others' practices of domination and unequal parts of privilege and oppression" (Haraway, 1991, p. 187). 
50). ${ }^{6}$ In any case, this question is quite hotly disputed, explains Londa Schiebinger, and remains in the realm of theory (Schiebinger 1999, p. II; see also Vendramin, 2018). In my opinion, the statement of all the women knowing the world differently (and, e.g., doing science differently) ${ }^{7}$ as all the men is too basic, too one-dimensional, not least because gender should be understood not primarily as an attribute of individuals but as an axis of social relations (Anderson, 1995; Grasswick, 2008). This means that, scepticism "about the idea of any unitary women's consciousness or unitary women's experience" (Bart, 1998) should be present. Being a feminist is a political identity, and political identities are "created in the flux of ideology and practice. They are not natural extensions of particular kinds of psyches or bodies" (Felski, 2000, p. 198).

Feminist theory began as an analysis of the ways in which knowledges discriminated against women and helped to develop and perpetuate harms done to women, both conceptually and materially; it emerged through a recognition of the inadequacy of existing models to explain women's positions in the past and their potential for change in the present and future. (Grosz, 2010, p. 49).

But, according to Elizabeth Grosz, it is important for the research focus to be both conceptual and empirical (although she states that her own focus is conceptual rather than empirical, so I hope I am not stretching the interpretation of her words too far),

not because the empirical has no place, but because, without a conceptual frame, the empirical has no value, no context, no power, it simply is. The empirical is given without some understanding of how it comes to be, without some assessment of its historicity and its potential to be otherwise. Only a framework, a context, which explains the forces that produce its givenness, can also show how it may be undone, or made differently (ibid.).

This is very much in line with what Donna Haraway writes in her seminal work Simians, Cyborgs and Women (1991, p. 82): feminism is “a

6 Some additional questions: is there such a thing as feminist science, is there perhaps a "female style" in science, do women do science differently to men (if so, how would this research differ from traditional research) (Vendramin, 2018, p. 76)?

7 This is a very vast theoretical territory into which we unfortunately cannot venture at this point. The thesis of automatic epistemic privilege (in other words: superior insight), which means that those who are oppressed or marginalised always know more, or always know better, because of their social/political location cannot always be backed up (see Wylie \& Sismondo, 20I5; italics are mine). For a reflection on this, see Felski, 2000, which in my opinion is a very succinct contribution on the politics of feminist identity. 
search for new stories, and so for a language which names a new vision of possibilities and limits. That is, feminism, like science is /.../ a contest for public knowledge".

Similarly, Eva Bahovec explicitly places feminism in the framework of epistemology and notes: the epistemological struggle of feminism is a clash with the category of the self-evident, with everything perceived as given, natural and unchangeable: "with everything that is only an appearance and therefore misleading" (Bahovec 2007, pp. 35-36). In short, I opt for the permanent resistance of the feminist epistemic subject towards the taken-for-granted, including itself and its constructions (Vendramin, 2014, p. 199).

We should return here to women's epistemic disenfranchisement. Phyllis Rooney believes this disenfranchisement needs to be made visible as women have been dismissed as "serious reasoners and knowers in a variety of knowledge areas and disciplines as well as in philosophy /and it/ continues to be a defining project in feminist epistemology" (Rooney, 20I0. p. IO). Thus, to remain within this line of thinking with the help of Miranda Fricker: "The cause of testimonial injustice ${ }^{8}$ is a prejudice through which the speaker is misjudged and perceived as epistemically lesser (a direct discrimination). This will tend to have negative effects on how they are perceived and treated non-epistemically too" (Fricker, 2017a, p. 54). But let us now turn the perspective around: those that are non-epistemically perceived to hold less "value" cannot authorise themselves epistemically in society as a whole (such as currently exists). So, to "the epistemological question 'Who can be legitimate knowers?' the answer has historically been, 'not women'” (Bart, 1998).

In short let me conclude, that feminist inquiries have "made significant contributions to the epistemological terrain as regards questions such as who can be 'knowers', or what sorts of experience can count as justification of knowledge claims" (Bart, 1998).

So, let us return to Nina Perger, Metka Mencin and Veronika Tašner's article to reflect on FE and threats posed to academia by governing neoliberal ideology that is "making deals with (extreme) right-wing political movements". Or, for example, reflect on endeavours "to create epistemological alliances with critical studies such as decolonial or antiracist research studies, among others", as writes Biljana Kašić. Or, as we can read in Renata Šribar's article, it is important to "transpose feminist epistemologies to class" if we want to practise feminist pedagogy. Similarly, Ana

8 Injustice as a "wrong done to someone specifically in their capacity as a knower" (Fricker, 2007 b, p. I) or a subject of knowledge (ibid., p. 5). 
Mladenović, among other things, gives an example of how to realize this approach in a feminist classroom. Further, we can venture into mediascape with Mirjana Adamović or look into the discourses of the "crisis of masculinity" and "feminisation" in school context with Majda Hrženjak, not to mention "discussions about gender and language, the diversity and rights of socially disadvantaged groups" that Mojca Šorli speaks of.

Here is our "power to see" (Haraway, 1991, p. 192).

\section{Literature}

Anderson, E. (2020). Feminist Epistemology and Philosophy of Science. In E. N. Zalta (Ed.), The Stanford Encyclopedia of Philosophy. Retrieved September 25, 2020, from plato.stanford.edu/archives/spr2020/ entries/feminism-epistemology/.

Anderson, E. (1995). Feminist Epistemology: An Interpretation and a Defense. Hypatia, Io(3), 50-84.

Bahovec, E. D. (2007). Freud, ženska in popotnikova senca. Delta.

Bahovec, E. D., \& Bregar-Golobič, K. (Eds.) (2004). Šola in vrtec skozi ogledalo. DZS.

Bart, J. (1998). Feminist Theories of Knowledge. The Good, the Bad, and the Ugly. Retrieved December II, 2020, from Feminist Theories of Knowledge: The Good, The Bad, and The Ugly (sbc.edu).

Felski, R. (2000). Doing Time. Feminist Theory and Postmodern Culture. New York University.

Fricker, M. (2017a). Evolving Concepts of Epistemic Injustice. In I. J. Kidd, J. Medina \& G. Pohlhaus, Jr. (Eds.), The Routledge Handbook of Epistemic Injustice (pp. 53-60). Routledge.

Fricker, M. (2017b). Epistemic Injustice. Power \& the Ethics of Knowing. Oxford University Press.

Grasswick, H. E. (20II). Introduction: Feminist Epistemology and Philosophy of Science in the Twenty-First Century. In H. E. Grasswick (Ed.), Feminist Epistemology and Philosophy of Science. Power in Knowledge (pp. xiii-xxx). Springer.

Grosz, E. (2010). The Untimeliness of Feminist Theory. NORA - Nordic Journal of Feminist and Gender Research, I8(I), 48-5I.

Janack, M. (n.d.). Feminist Epistemology. The Internet Encyclopedia of Philosophy. Retrieved September 25, 2020, from http://www.iep.utm. edu/fem-epis/.

Longino, H. (1987). Can There be a Feminist Science? Hypatia, 2(3), 51-64. 
Lykke, N. (2010). The Timeliness of Post-Constructionism. NORANordic Journal of Feminist and Gender Research, I8(2), I3I-I36.

Rooney, Ph. (2011). The Marginalization of Feminist Epistemology and What That Reveals About Epistemology "Proper”. In H. E. Grasswick (Ed.), Feminist Epistemology and Philosophy of Science. Power in Knowledge (pp. 3-24). Springer.

Schiebinger, L. (1999). Has Feminism Changed Science? Harvard University Press.

Van der Tuin, I. (2016). Feminist Epistemology. Wiley Online Library. Retrieved September 24, 2020, from https://onlinelibrary.wiley.com/ doi/abs/10.1002/9781118663219.wbegsso42.

Vendramin, V. (2018). Women and Science: Feminist Shifts in Theory and Practice. In M. Gadpaille, V. Kondrič Horvat \& V. Kennedy (Eds.), Engendering Difference: Sexism, Power and Politics (pp. 72-84). Cambridge Scholars Publishing.

Vendramin, V. (2015). Epistemological (and Some Methodological) Aspects of the Gendered Perspective in Science. In M. Ule, R. Šribar \& A. Umek-Venturini (Eds.), Gendering Science: Slovenian Surveys and Studies in the EU Paradigms (pp. 6I-74). Echoraum.

Vendramin, V. (2014). Epistemic Subjects and Situated Knowledges: Women, Feminists and Others. In M.Z. G. de Abreu \& S. Fleetwood (Eds.), Women Past and Present: Biographic and Multidisciplinary Studies (pp. 194-200). Cambridge Scholars Publishing.

Vendramin, V. (2009). Od kod prihajajo dejstva?: feminizem in transformacije nekaterih temeljnih epistemoloških pojmov. Dialogi, 45(II/I2), $57-68$.

Wylie, A., \& Sismondo, S. (20I5). Standpoint Theory. In J. D. Wright \& M. E. Lynch (Eds.), Science In: International Encyclopedia of the Social and Behavioral Sciences (pp. 324-330). Elsevier. 


\section{Reviews}

Mary Beard: Women \& Power: A Manifesto. London: Profile Books, 2018.

"But if we want to understand - and do something about - the fact that women, even when they are not silenced, still have to pay a very high price for being heard, we need to recognise that it is a bit more complicated and that there is a long back story" (p. 8). The power of speech that is heard is not just a starting point but a central theme of the manifesto Women and Power by Mary Beard. The manifesto is divided into two parts, the first is entitled Women's Voice in Public and the second Women and Power, which are closely intertwined. The 2018 edition of Women and Power (the first edition is from 2017) revisits the agenda a year after the beginnings of the \#metoo movement (the "world's most famous hashtag", as noted by Mary Beard, p. 98) and in the Afterword reflects on new discourses on rape and sexual harassment.

Mary Beard thus unfolds cultural and historical moments from Greek and Roman antiquity to the American period of slavery and the present, all through the central theme of the power of women's voice in public. But, at the same time, the enterprise does not slip into a simple collection of cases of the silencing and oppressing of women, which is not so uncommon for descriptions of overlooked women and their works, rebellion and history. At the end, such "collections" appear more as complementing the "main" history or as its decoration, exactly there where is the place for a woman, a place of silent decoration behind the glass cabinet. Mary Beard, on the contrary, with her scientific sharpness and essayistic narrative style points to elements which are crucial and common 
to emancipation, which is the power (or weakness) of the female voice in public space. The struggle for women's emancipation is thus a struggle for this voice, to be heard and to be able to take over political power as well. Only then will women's voice not sink into the deafness of silence. As she writes "My aim here is to take a long view, on the cultural awkward relationship between the voice of women and the public sphere of speech - making, debate and comment: politics in its widest sense, from office committees to the floor of the House" (p. 8).

When Mary Beard thus takes us through countless stories and characters from the culture history and shows the attempts to silence women are so loud that the Meta from Ivan Tavčar's dystopian novel $4000^{1}$ simply cannot be overlooked. The scene where the father lieutenant complains to the father major about his "unbearable unfortunate" as a result of the new regulation, which imposes silence on women, is eloquent:

So, old Meta is with me and she is a good soul, and certainly a poor soul. Ever since Archbishop Martinus introduced the strictest regulation of Blessed Anton of Kal - now half a year since it is imposed - every speaking has been forbidden to women. You know that! My Meta hadn't uttered a word in six months, but she carries millions of words within her. These words, which are locked in her now, force out everywhere, from her eyes, from her ears. Oh, how she twisted, how she sighed, how she pursed her mouth, but she was not allowed to speak, if she did not want to take part in mortal sin and if she did not want to fall for the ruthless Inquisition against women's speaking! (Tavčar, 1948, p. 39)

Although the father lieutenant was afraid Meta would suffer a stroke and that she would be suffocated by talking, "which is certainly possible with a woman" (ibid., p. 39), he did not want to order the stretcher of the blessed Anton of Kal. ${ }^{2}$ This device namely "successfully clogs the women's mouth" in such cases, but "it covers the woman's face too much and this is the most beautiful in a woman!" (ibid., pp. 39-40) and "wounds

Ivan Tavčar's satirical dystopian novel 4000 was published in 1891 and is mainly a reflection of the political and cultural conflicts between clericals and liberals in the territory of today's Slovenia, which was then part of the Austro-Hungarian monarchy. The novel takes place in the year 4000 in Ljubljana, which is again named Emona (the Latin name for Ljubljana during the time of the Roman empire), and the territory of Slovenia is named Pope's Province number LII. The novel begins when the angel Azrael awakens a Slovenian liberal who died 2000 years before and shows him the orders and habits in Emona, which, naturally, are the image of th ideas spread in the then clerical circle in Tavčar's time.

2 The character of Blessed Anton of Kal is based on the most conservative leader of the cleric wing Anton Mahnič, who lived in Tavčar's time, wrote in Latin and as an educator preached about the danger and corrupting influence of the German and Slovenian poets, writers and philosophers being taught to students in public schools at that time. 
and blisters occur on the neck which is also a beautiful thing!" (ibid., p. 40). The father lieutenant hence instead decided to ask for a dispensation, which he obtained through a formal request and a bribe. Meta was thus able to speak every 3 weeks for I day without "disengaging from the commandment of blessed Anton of Kal, by which a woman in eternal wisdom is forbidden any speech" (ibid., p. 40). The scene ends when the father lieutenant together with the father major are drinking wine in comfort and complaining about the "unfortunate" and Meta, who now has permission to speak after 3 weeks, suddenly interrupts them. She insults them both for being drunks and chases them away.

The story of Meta condenses all of the key elements of silencing a woman and woman's place in society. Tavčar, with the exact targeting of the misogyny and silencing of women in the figure of Meta, presents the whole dimension of this structure. On one hand, there is the silence of a woman and the importance of her beauty and, on the other, if a woman's speech is allowed (of course only in the domestic sphere), is the woman's speaking only the uproarious outbreaks of uncontrolled talking and Xantipe's grumpiness, which destroys pleasant hanging out with friends with a glass of wine?

Women's bodies are not only twisted by the patriarchal beauty ideal, but also by the often emphasised authority of the deep male voice as opposed to the female one. This is exactly, says Mary Beard (p. 39), what Margaret Teacher did when she lowered her tone of voice with the help of special voice training, thus giving it an authoritative tone which, according to the counsellors, her high voice was lacking in. When listeners hear a female voice, they still do not hear a voice that connotes authority, they have not learned how to hear authority in it and they do not hear muthos. But it is not just voice, we can also add in a wrinkled face, which for a man indicates mature wisdom and for a woman that her date has expired (p. 3I).

Namely, if a woman's voice is heard in public, it is because of »androgyny or because it is a voice raised in support of women's causes, which is also not unimportant but, as Mary Beard points out, women's public speech has been pushed into this framework for centuries (p. 25).

On the other hand, many aspects of the traditional set of views on the general unsuitability of women for public speaking are still contain a premise of awkwardness with the female voice in public. When women speak in public, they are "strident", they "whinge" and "whine" (p. 29). "Do those words matter?", asks Mary Beard (p. 30), answering: "Of course they do" (p. 30): because they remove authority, force, and even humour from the female voice. This idiom actually effectively returns women back 
to the domestic sphere (people whinge doing the dishes) trivialises their words or re-privatises them (p. 30). Such attitudes, assumptions and prejudices are hard-wired in us: not in our brains but in our culture, language and history (p. 33).

A few months ago, in an evening daily news programme on Slovenian commercial television, ${ }^{3}$ we were witnesses to such an attempt to silence the woman speaker. The guests in the show were the president of a rightwing populist party, who is also a member of parliament, and the president of the trade union that unites young employees. The union president, who is otherwise a very articulate speaker, successfully criticised the topic and defended the politician's constant attacks and attempts to silence her. He namely kept interrupting and discrediting her in an attempt to silence her with statements such as: "Stop blabbering on ... I pay taxes and you don't ... Lady, stop talking rubbish ... You have beautiful red hair, beautiful eyes, a charming smile ...”. And after that, when the presenter of the show carefully reminded him to stop, he complained that he had only told her that she is beautiful and wondered what actually the problem was with this. At the same time, during the whole talk the presenter with almost no interventions actually enabled this situation. In short, the presenter was not trying to stop the politician; she left the trade union speaker to the gladiator's combat for the price of ratings?! The chatter, the "rubbish" talk of the woman, the remarks about her beauty are exactly the silencers of women's voices. It really does not take much, just a small remark about babbling and beauty, because the cultural-historical context is already in background and strong enough.

Mary Beard underlines a tradition of gendered speaking to which we are still directly, or more often indirectly, the heirs. Western culture does not owe everything to the Greeks and Romans (p. 20). "And those 19th century gentlemen who designed or enshrined, most of the parliamentary rules and procedures in the House of commons were brought up in exactly those classical theories, slogans and prejudices", continues Mary Beard. "Again, we are not simply victims or dupes of our classical inheritance but the classical tradition has provided us with a powerful template for thinking about public speech, and for deciding what counts as a good oratory or bad, persuasive or not, and whose speech is to be given space to be heard. And gender is obviously an important part of that mix" (p. 2I).

Female politicians are still seen as a disturbing image and a threat to the orderly world, and so it is the good Amazon who can only be a dead Amazon. The beheaded Medusa remains a cultural symbol of resistance 
and female power and most of the prominent female politicians are often associated with these characters as Mary Beard shows, they are Medusas, Clytaemnestres, Lizistrates etc. But not only women politicians in power are exposed to attacks. Marta Verginella (2019) in her preface to the Slovenian edition of Women and Power by mentioning Greta Thunberg and Carola Rousseff, two women who raise their voice not only for themselves but also for others, reminds us how they were immediately attacked ad hominem and labelled as problematic, insane, furious etc. - not because of what they did, but that they as women dare to speak and act in public.

At the end, it is important to again mention that Mary Beard's Woman and Power is subtitled Manifesto. Woman and Power is not a small essay, a booklet on women's public voice and their struggles, but a manifesto in the full sense of the word. The manifesto is a public statement of beliefs, aims and policies and is actually a written word in a public space. The book can also be read in the domestic sphere in the shelter of the home on the couch, but the only place of the manifesto is in the public square where it can also be heard and where a word becomes an act.

\section{Literature}

Beard, M. (2019). Ženske in oblast: Manifest. Znanstvena založba Filozofske fakultete.

Tavčar, I. (1948). 4000 : času primerna povest iz prihodnjih dob: po vzorih $d r$. Ničmaha napisal dr. Nevesekdo. Slovenski knjižni zavod.

Verginella, M. (2019). "Ko bodo celo mačke nehale moriti ptice". In Ženske in oblast: Manifest. Znanstvena založba Filozofske fakultete.

\section{Sabina Autor}

https://doi.org/10.32320/1581-6044.31(5-6)147-151

Sara Ahmed: What's the Use? On the Uses of Use. Durham and London: Duke University Press, 2019.

What's the Use? is designated as the third and final part of Sara Ahmed's trilogy concerning "following words" (p. 3) - tracing their intellectual and social history, stories of how words and ideas have been put to use. The first one, The Promise of Happiness (2010), focuses on tracing happiness as an idea or even as an obligation (to be happy) that is accompanied by socially shaped expectations concerning what brings happiness. These expectations also serve as demands to be met in order to be happy. The 
second one, Willful Subjects (2OI 4), focuses on wilfulness as a designation of those who do not "will" in the right way - in the way that is expected from them; of those who stray from the already-made, well-trodden social paths. The conclusion of both works (2010; 2014) may be summarised as: "Happiness follows for those who will right" (2014, p. 4). In the last part of her trilogy, Sara Ahmed adds another crucial dimension to the analysis of the quite complex socio-political dynamics of social exclusion and marginalisation, and the ways in which the world-as-it-is stays as-it-is, namely, the use of use and its accompanying designations, especially the interplay and the conditions of being designated as useful or useless.

In the first chapter "Using Things", she focuses on the everyday life of use: "how objects can be caught at different moments of use" (p. 65) of being in use, out of use, used, unused, overused, used up, usable/unusable, concluding by highlighting the power of classification in terms of designating objects and agents by assigning them the above-mentioned use-related qualities. In What's the Use?, S. Ahmed expands the repertoire of a critical gaze - previously mostly focused on race (20I2), gender and sexuality (2010; 2014; 2017), while other dimensions were undoubtedly present at least in-between the lines - to include disability and class. By discussing intended functionality or forness, approached as a description of "what something is for" (2019, p. 2I), she also deepens her previous discussions of the relations between objects and orientations: "Orientation involves direction toward objects that affect what we do, and how we inhabit space. We move toward and away from objects depending on how we are moved by them" (2006, p. 28). Intended functionality also accounts for how objects (spaces) - the social as instituted (Bourdieu, 2020, p. 26) - also contain an orientation towards agents by being shaped in a way that enables spaces to be used by some rather than all agents. By their shape, spaces reach towards particular groups of agents and are being reached for by them: it is this simultaneousness or, better, the lack of it, which reveals forness not only as a function of an object, but also for whom an object is to be useful.

In order to reveal use as an inheritance, Ahmed follows the paths of intellectual use of use by Darwin and Lamarck. She traces their steps and tracks, left in the field of social sciences - as evident in the works of Herbert Spencer - which were at the time attempting to constitute themselves as a legitimate scientific discipline of sociology by adopting and following the steps of natural sciences (Durkheim \& Fauconnet, 1903/2014), Ahmed discusses: I) law of use and disuse: "what is used will be strengthened in proportion to time spent"; and 2) natural selection: "the effects of repeated use will be inherited by future generation" (p. 85). According to 
S. Ahmed and her discussion of the blacksmith's arm - a story of the laws of exercise and natural selection, of inheritance of what one is capable of being useful to, a story of a blacksmith's son following his father's path by inheriting his stronger arms (pp. 85-102) - is not only a demand to be useful unequally distributed on the basis of race and class (some are freed from the obligation to be useful), but also contains a particular temporality of spreading across generations. When the use is what one inherits, it is a "prediction" and a "command" (p. 90) to be useful for something rather than other that it is inherited. It is a partiality of an existence, a particular forness extracted from all the possibilities of what one could be (p. 2I). As S. Ahmed discusses in the following chapters on use as a technique and on use and the university, the education system is one of the clearest examples of a directive mechanism, tending to put that inheritance to use.

In Chapters 3 and 4, Ahmed shows how intended functionality is not the only principle guiding the usage either of an object or an agent. Namely, alongside intended functionality that is evident and generally clear, for example via explicit instructions or proclamations, there is also an additional part of functionality, one that stays silent or hidden, but which nonetheless results in a particular usage and the effects that stem from it. It is, as Bourdieu (1998, p. I13) analyses in relation to the economy of symbolic goods, this "double consciousness" of an institution or of a field whose entire logic rests "on the taboo of rendering / the truth/ explicit". By referring to the use as an inheritance and use as a technique, and applying it to the analysis of the monitorial schools for working class children in England in the early $19^{\text {th }}$ century under the guidance of Andrew Bell and Joseph Lancaster, S. Ahmed makes visible the gap and the tension between the "official" truth of the field of education - usefulness, and its repressed truth, reproduction.

At the beginning, the analysis of education and use refers to the monitorial schools, enveloped with fears of "the danger of education" - of engendering insubordination rather than passive subordination to one's social destiny that is achieved by limiting agents' aspirations - but further chapters aim to show how education and reproduction are entangled in the context of university. Despite S. Ahmed's claim in Chapter 4: "/a/ccounting for use and the university is thus a way of bringing the arguments of each of my three preceding chapters together" (p. 144), the leap from the monitorial schools of the rigth century to the founding of University College London (UCL) in 1826 , and to the modern university - analysed from the perspective of diversity, of complaint and of queer use - seems to provide us with an idea of quite a linear continuation as if the educational field is destined solely for its reproductive role, disregarding 
its ambivalent role in providing resources, possibilities and opportunities to reach further than one is destined for; its role, after all, to enable queer use at the same time as disabling it.

In her analysis of university, S. Ahmed shows how the use of use, when intertwined with usages of other (class-based, race-based etc.) ideas, such as intended functionality or forness - what one is for, thus, what one should aim and aspire to - results in what she names "institutional mechanics" (p. I5I) that are supported by "institutional reluctance" (p. I49) and "nonperformativity" (p. 153). This conglomerate of "what usually happens still happens" (p. 152), of an "institutional as usual" (p. 163), serves as a barrier, a wall, to any attempts of (attempting a) change, a wall that is usually visible only to the misfits who attempt to queer the use, the usu$\mathrm{al}$, and the usual use (see the Conclusion for queer use). In her discussion on misfits and queer use, on "how things can be used in ways other than for which they were intended or by those other than for whom they were intended" (p. 199), S. Ahmed focuses on queer(-ing) agents, putting aside that institutions provide grounds not only for their own reproduction, but also for their own transformation.

In her trilogy, S. Ahmed follows the words and ideas of happiness (2010), wilfulness (2014) and use (2019). By tracing the idea of use along the lines of - to remain with her use of the path metaphor (p. 40) - its well-trodden paths, she trails the ways in which use as an idea and as an everyday life practice shape institutions, brick by brick, and the everyday life of social agents, wall by wall - but also arm by arm, by a supportive, change-enacting "army of arms" (2017, p. 84). Expressed differently, she trails the paths that were used before by, for example, M. Douglas on how institutions think (1986), and Bourdieu's analyses (for example 1996; 20I8), but which are in dire need of being used more, especially nowadays when the educational field (still) seems to be failing to live up to its official truth, meritocracy. Yet, failing to enact meritocracy is not the only thing it does.

\section{References}

Ahmed, S. (2006). Queer Phenomenology: Orientations, Objects, Others. Duke University Press.

Ahmed, S. (2010). The Promise of Happiness. Duke University Press.

Ahmed, S. (2012). On Being Included: Racism and Diversity in Institutional Life. Duke University Press.

Ahmed, S. (2014). Willful Subjects. Duke University Press.

Ahmed, S. (2017). Living a Feminist Life. Duke University Press. 
REVIEWS

Bourdieu, P. (1996). The State Nobility. Polity Press.

Bourdieu, P. (1998). Practical Reason: On the Theory of Action. Stanford University Press.

Bourdieu, P. (2018). Classification Struggles: General Sociology, volume I, Lectures at the College de France, 1981-1982. Polity Press.

Bourdieu, P. (2020). Habitus and Field: General Sociology, volume 2, Lectures at the College de France, 1982-1983. Polity Press.

Douglas, M. (1986). How Institutions Think. Syracuse University Press.

Durkheim, É., \& Fauconnet, P. (2014). Sociology and the Social Sciences.

In É. Durkheim, The Rules of Sociological Method and Selected Texts on Sociology and its Method (pp. 130-157). Free Press.

\section{Nina Perger}

https://doi.org/10.32320/1581-6044.31(5-6)15I-155 



\section{Abstracts • Povzetki}

Nina Perger, Metka Mencin and Veronika Tašner

\section{TEACHING FEMINISM: BETWEEN MARGINALISATION AND FEMINIST PERSISTENCE}

The aim of this article is to gain insights into how feminist principles, content and practices persist in higher education in times of neoliberal ideology, post-feminism and the intensification of extreme-right wing politics. The main issue the article seeks to address is the state of gender-related and feminist topics in higher education. Their state should be addressed at the intersections of: I) social context; 2) institutional settings (formalised and officialised gender-related curricula); and 3) intra-institutional practices, such as backlashes to and sanctions against feminist practices. In order to achieve this, we start by briefly sketching the beginnings of women's studies worldwide, and the ambivalences of institutionalising feminist knowledge. We proceed by focusing our discussion on the contemporary social situation, significantly marked by right-wing politics and neoliberal ideology, aiming to constitute feminism as irrelevant on the grounds of an individualised "brave new world", where everything seems possible, achievable and accessible. We continue by focusing our attention on the state of feminist topics in the context of Slovenian higher education. This part is based on document analysis of curricula of various universities in Slovenia (a description of their study courses and programmes: the research shows that gender-related topics are still marginalised within higher education as feminist topics remain rare and optional rather than obligatory. After discussing the barriers and obstacles facing feminism, we conclude with a discussion on feminist persistence and resistance in higher education: it is 
still persisting despite the backlashes that seek to extort a price for doing feminism, even if feminist practices are forced to take a more subtle form. Keywords: feminism, women's studies, higher education, curricula, resistance

\section{POUČEVATI FEMINIZEM: MED MARGINALIZIRANOSTJO IN FEMINISTIČNO VZTRAJNOSTJO}

Cilj prispevka je pridobiti vpogled $v$ načine, kako feministična načela, vsebine in prakse vztrajajo $\mathrm{v}$ visokem šolstvu $\mathrm{v}$ času neoliberalne ideologije, postfeminizma in stopnjevanja skrajno desne politike. Osrednja tema članka je položaj programov in vsebin, povezanih s spoli in feminističnimi temami v visokem šolstvu, ki bi ga bilo treba obravnavati na presečiščih: I) družbenega konteksta, 2) institucionalnih okolij (formalizirani in uradni učni načrti, povezani s spolom) in 3) (znotraj) institucionalnih praks, kot so negativne reakcije in sankcije proti feminističnim praksam. Zato v uvodnem delu najprej povzamemo začetke ženskih študijev po svetu in pokažemo na ambivalentnost institucionalizacije feminističnih vednosti. Nadaljujemo $s$ kratko analizo aktualnih družbenih in političnih okoliščin, zaznamovanih s sprego desničarske/konservativne politike in neoliberalne ideologije, ki daje vtis nepomembnosti in pogrešljivosti feminizma, kar počne na ozadju iluzije individualiziranega $\gg$ krasnega novega sveta«, kjer se zdi vse mogoče, dosegljivo in dostopno. Sledi pregled stanja feminističnih tem v kontekstu slovenskega visokega šolstva. Ta del temelji na analizi dokumentov: učnih načrtov in predstavitvenih zbornikov pedagoških fakultet treh slovenskih univerz. Raziskava pokaže, da spoli oz. enakost med spoli ter feministične teme $v$ visokem šolstvu ostajajo še vedno marginalizirane. Predmeti, ki so v celoti posvečeni omenjenim temam, so še zmeraj redki in ostajajo na ravni izbirnih, torej neobveznih vsebin. Po razpravi o ovirah in preprekah, s katerimi se sooča feminizem, članek zaključimo z razpravo o feministični vztrajnosti in odpornosti na ovire v visokem šolstvu. Ta še vedno vztraja kljub negativnemu odnosu do feminizma, četudi so feministične prakse neredko prisiljene sprejeti bolj subtilno obliko.

Ključne besede: feminizem, ženske študije, visoko šolstvo, kurikulum, odpor 


\section{Biljana Kašić}

\section{FEMINISM AS EPISTEMIC DISOBEDIENCE}

AND TRANSFORMATIVE KNOWLEDGE: EXPLORATION OF AN ALTERNATIVE EDUCATIONAL CENTRE

Living under the threat of demonising feminism along with its de-politicisation and commodification in an age of "postfeminist sensibility" (Gill, 2007), and the reduction of women's/gender studies programmes worldwide is more than a reason to revisit the feminist politics of knowledge here and now. Since the neoliberal trend is impregnated "with old-fashioned academic design that counts on (neo)conservativism" (Kašić, 20ı6), retrograde claims and (neo)traditional morality, one challenge is how to respond to the sexist, androcentric, anti-gender and racist assumptions that are deepening inequality and fostering social exclusion and discrimination as well as to disrupting the mainstream knowledge of scientificity (Pereira, 2017). By using the Centre for Women's Studies in Zagreb as an example, the paper argues that an alternative form of education outside mainstream academic institutions, despite various obstacles and inner problems, can ensure a freeing up from hegemonic and misogynist knowledge more than a university education by creating a powerful space toward feminism as an epistemic disobedience and activist theory, and by providing the political subjectivisation of both teachers and students. In this regard, three topics are of analytical interest here: feminism as subversive knowledge; critical pedagogy from the perspective of "epistemology of discomfort"; and the potential held by feminism as an engaged (activist) theory. The questions and themes proposed are not new but continue on previous epistemic dilemmas and disputes both around feminism and progressive ideas around education, and coming to terms with feminist urgency and ethical responsibility (Spivak, 2012).

Key words: women's studies, feminism, "pedagogy of discomfort", alternative education, epistemic disobedience

\section{FEMINIZEM KOT EPISTEMSKA NEPOSLUŠNOST \\ IN TRANSFORMATIVNA VEDNOST: VPOGLED V ALTERNATIVNI IZOBRAŽEVALNI CENTER}

Življenje pod grožnjo demoniziranja feminizma, skupaj z njegovo depolitizacijo in komodifikacijo v času »postfeministične senzibilnosti« (Gill, 2007), in redukcija ženskih študij/študij spolov po vsem svetu pomenijo več kot le poziv $\mathrm{k}$ ponovnem obratu $\mathrm{k}$ feministični politiki vednosti tukaj in sedaj. Ker je neoliberalni trend prepojen »s staromodno akademsko obliko, ki se opira na (neo)konzervatizem (Kašić, 2016), retrogradnimi izjavami in (neo)tradicionalno moralnostjo, je eden od izzivov, kako 
se odzvati na seksistične, androcentrične, proti spolu uperjene in rasistične predpostavke, ki poglabljajo neenakosti in spodbujajo družbeno izključenost, ter kako prekiniti prevladujočo vednost znanstvenosti (Pereira, 2017). Prispevek uporabi Center za ženske študije v Zagrebu kot primer in zagovarja tezo, da alternativna oblika izobraževanja zunaj prevladujočih akademskih institucij, kljub različnim oviram in notranjim problemom, lahko zagotovi osvoboditev od hegemone in mizogine vednosti bolj kot univerzitetno izobraževanje, in sicer tako, da ustvari vplivni prostor za feminizem kot epistemsko neposlušnost in aktivistično teorijo ter da zagotovi politično subjektivizacijo tako učiteljic kot učenk. $V$ tem smislu so tu v ospredju analitičnega zanimanja tri tematike: feminizem kot subverzivna vednost; kritična pedagogika s perspektive »epistemologije nelagodja «; in potenciali feminizma kot angažirane (aktivistične) teorije. Vprašanja in teme, ki so predlagane tukaj, niso nove, ampak pomenijo nadaljevanje predhodnih epistemskih dilem in razprav tako glede feminizma in progresivnih idej o izobraževanju, kot sprejemanje feministične nuje in etične odgovornosti (Spivak, 2012).

Ključne besede: ženske študije, feminizem, »pedagogika nelagodja «, alternativno izobraževanje, epistemska neposlušnost

Renata Šribar

\section{STUDY IN A VIRTUAL CLASS: DOINGS OF FEMINIST PEDAGOGY AND COVID-19 CRISIS}

While reflecting on our lecturing practices, many of us feminists wish to deconstruct the ex-cathedra teaching position and its symbolic effects. After initial inquiry into feminist pedagogy, the present discussion combines basic information with the author's teaching practice: underway in tertiary-level education and involving University of Ljubljana students. Some of the preconceived and some spontaneous, yet informed teaching approaches have been tested with positive results, and are worth sharing. They are accompanied by certain concepts, and their applied use which is presented on the list of teaching/learning topoi.

Personal advancement in terms of more knowledgeable, skilled and emotionally fulfilling teaching and learning occurred in the first phase of the anti-Covid-I9 regime and the virtual studying. The heavy working overload and new teaching and learning technological mode have pushed me towards the vivified and inventive "moderation" of Zoom and Google study meetings. The flexibility of the web lectures and seminars has promoted the invention of less conventional and coded communication, and the situational introduction of actual socio-political topics not inscribed 160 
in the curriculum. One of these outer topics was "gender relations in the anti-Covid-rs regime". The search for novel teaching and learning practices has induced the need to systematise work practices. Reorganisation has been conceptual: the triangulation of students, the "object" (subject matter, related experience, and embodiment through feelings), the teacher. The quality of studying by way of the two way-transfer of knowledges and transferable skills has been proven while working together with students in research experiment at one of the subjects.

Key words: triangulation, transformation, study “object”, embodied experience, emotions

\section{ŠTUDIJA V VIRTUALNI PREDAVALNICI: DELO FEMINISTIČNE PEDAGOGIKE IN COVID-19 KRIZA}

Ob refleksiji lastnih predavateljskih praks si marsikatere feministke želimo dekonstruirati položaj ex cathedra in njegove simbolne učinke. Sledeč začetnemu vpogledu v študije feministične pedagogike pričujoča razprava združuje osnovne informacije in avtoričino učno prakso: potekala je na terciarni ravni in vključevala študentke in študente Univerze v Ljubljani. Nekateri vnaprej pripravljeni in nekateri spontani, a informirani pristopi poučevanja so bili že preizkušeni in so prinesli pozitivnime rezultate. Mislim, da jih je vredno deliti. Pospremila sem jih z nekaterimi koncepti in njihovo rabo. Predstavljam v obliki predavateljskega seznama / učenja tematskih občih mest.

Osebni napredek v smeri bolj načitanega, usposobljenega poučevanja in učenja, ki nosi s seboj čustveno izpolnitev, se je zgodil v prvi fazi režima, ki se je vzpostavil proti Covidu-ı, in virtualnega študijskega procesa. Močna delovna preobremenitev in tehnološko nov način poučevanja in učenja sta me navedla $\mathrm{k}$ živahnemu in iznajdljivemu »moderiranju« Zoom in Google študijskih srečanj. Z vidika tehničnih možnosti prilagodljiva spletna predavanja in seminarji sta spodbudila iznajdevanje manj običajne in kodirane učne komunikacije in situacijsko uvajanje aktualnih družbeno-političnih tem, ki niso vključene v učni načrt. Ena od takih predhodno nenačrtovanih tem je bila »ospoljeni odnosi v režimu proti Covidu-I9《. Iskanje novih praks poučevanja in učenja je botrovalo nuji po sistematizaciji delovne prakse. Reorganizacija je bila konceptualna: triangulacija študentov in študentk, »objekta« (tj. učna tema, z njo povezana izkušnja in njeno utelešenje skozi občutke), predavateljice oz. predavatelja. Kakovost študija skozi dvosmeren prenos znanj in prenosljivih veščin sem preverila pri enem od predmetov v sodelovanju s študentkami in študenti tekom skupnega raziskovalnega eksperimenta. 
Ključne besede: triangulacija, transformacija, študijski »objekt«, utelešena izkušnja, čustva

\section{Ana Mladenović}

\section{FEMINIST CLASSROOMS IN PRACTICE}

Feminist pedagogy is a way of thinking about teaching and learning that guides our choice of classroom practices (Shrewsbury, 1987). As such, it is used in different ways within and across disciplines. Feminist pedagogy offers a critical perspective on gender-related issues in everyday life and in the educational process and facilitates transformative teaching and learning situations characterised by alternative conceptions of power and power relations. This paper focuses primarily on the teaching and learning process, reflecting different aspects and elements of feminist pedagogy important in the context of the educational process itself. The key question in this regard is: what makes feminist classrooms feminist? The paper starts by defining feminist pedagogy, focusing on its transformative power. It goes on to highlight the importance of integrating feminist pedagogy throughout the entire education system. Examples of feminist classrooms on different education levels are given, starting with preschool education and continuing with primary and secondary education. A few of the practices presented were acquired in the literature review, but the majority of others, especially for the primary and secondary levels, was reported in a semi-structured interview with a teacher in training. In the conclusion, the need to include feminist pedagogy in teacher training programmes is stressed.

Keywords: feminist pedagogy, teaching and learning, feminist classrooms, gender, education levels

\section{FEMINISTIČNE UČILNICE V PRAKSI}

Feministično pedagogiko zaznamuje način razmišljanja o poučevanju in učenju, ki narekuje izbiro praks, ki se uporabljajo v učilnicah (Shewsbury, 1987). Feministična pedagogika je tako uporabna na različne načine znotraj posameznih disciplin, pa tudi med njimi. Ponuja kritičen pogled na vprašanja, ki zadevajo spol, tako v vsakdanjem življenju kot tudi v edukacijskem procesu in vpeljuje transformativno učenje in poučevanje, zaznamovano $\mathrm{z}$ alternativno koncepcijo moči in odnosov moči. Prispevek se osredotoča predvsem na dogajanje v učilnicah, to je na proces učenja in poučevanja, skozi refleksijo različnih vidikov in elementov feministične pedagogike, ki so pomembni v kontekstu samega edukacijskega procesa. V tem smislu je ključno vprašanje: kaj je tisto, kar dela feministične učilnice - feministične? Najprej je definirana feministična pedagogika, 
pri čemer je v središču zanimanja predvsem njena transformativna moč. V nadaljevanju je poudarjena pomembnost integracije feministične pedagogike skozi izobraževalno vertikalo. Predstavljeni so primeri feminističnih učilnic v predšolski vzgoji, osnovnem in srednjem šolstvu. Nekaj primerov je bilo pridobljenih s pregledom literature, večina, sploh na osnovnošolski in srednješolski ravni, pa $\mathrm{v}$ obliki polstrukturiranega intervjuja $\mathrm{z}$ bodočo učiteljico. V zaključku je izpostavljena smiselnost vključevanja elementov feministične pedagogike $\mathrm{v}$ programe usposabljanja bodočih učiteljev in učiteljic.

Ključne besede: feministična pedagogika, učenje in poučevanje, feministične učilnice, spol, ravni izobrazbe

\section{Mirjana Adamović}

\section{WHAT CAN WE LEARN ABOUT FEMINISM FROM WEB PORTALS?} - ANALYSING MEDIA BULLETINS

In contemporary society, the media is a powerful social force capable of actively supporting but also negating feminist values, even though the feminist perspective is today woven into the political and institutional lives of Western countries (McRobbie, 2009). Feminism is considered to be instrumentalised and words such as "empowerment" and "choice" are often used in the media and popular culture "as a kind of substitute for feminism" (McRobbie, 2009). This paper presents a media analysis of articles published by the five most visited Croatian web portals in 2019. The content of the articles was analysed by the qualitative method of thematic analysis. The results show that feminism is a neglected topic on web portals and most often found in "news", "culture" or "film" sections. The results of the thematic analysis identified five thematic frameworks which encompass the published articles: feminist pioneers, female politicians and feminism, celebrity feminism, feminist activism, and feminism and film. The first framework "feminist pioneers", along with the "feminist activism" framework, are more educational in the nature of their reporting, while the "celebrity feminism" framework deals more with the topics of violence towards women, women's relationship with their bodies and gender equality in general. The presentation of female politicians within the framework dealing with politics and feminism is the most neglected because it is practically devoid of any political-feminist content while the "film and feminism" framework is almost entertaining in character because it is mostly based on commenting on movie characters and their lifestyles as well as screenwriter choices. Although all of the identified frameworks mention and broach a series of subthemes, except in the case 
of feminist activism, these subthemes are not problematised nor can the audience reach a wider comprehension. Young people, as regular consumers of news content on the most visited web portals, cannot acquire a realistic image of feminism, and in rare occasional news items can they obtain a cursory education on feminist values.

Key words: feminism, media, celebrity, film, politicians, activism

\section{KAJ SE O FEMINIZMU LAHKO NAUČIMO S SPLETNIH PORTALOV? - ANALIZA MEDIJSKIH BILTENOV}

V sodobni družbi so mediji močna družbena sila, ki lahko aktivno podpira, a tudi negira feministične vrednote, ne glede na to, da je danes feministična perspektiva vtkana $\mathrm{v}$ politična in institucionalna življenja zahodnih držav (McRobbie, 2009). Feminizem naj bi bil instrumentaliziran in besede, kot sta »opolnomočenje « in »izbira«, so pogosto uporabljene v medijih in popularni kulturi »kot neke vrste nadomestek za feminizem « (McRobbie, 2009). Ta prispevek predstavlja medijsko analizo člankov, ki so izšli na petih najbolj obiskanih hrvaških spletnih portalih v letu 2019. Vsebina člankov je bila analizirana $s$ kvalitativno metodo, tj. tematsko analizo. Rezultati kažejo, da je feminizem zapostavljena tema na spletnih portalih in ga najpogosteje najdemo $v$ delih, ki pokrivajo $\gg$ novice $\ll, ~ \gg k u l-$ turo « ali $\gg$ film $\ll$. V rezultatih tematske analize je prepoznanih pet tematskih sklopov, ki vključujejo objavljene članke: feministične pionirke, političarke in feminizem, zvezdniški feminizem, feministični aktivizem ter feminizem in film. Prvi sklop »feministične pionirke «, skupaj s sklopom »feministični aktivizem «, je bolj izobraževalen po naravi poročanja, medtem ko se »zvezdniški feminizem « bolj ukvarja s tematiko nasilja do žensk, odnosom žensk do svojih teles in enakostjo med spoli na splošno. Predstavitev političark v sklopu, ki se ukvarja s politiko in feminizmom, je najbolj zapostavljen, ker praktično nima nobene politično-feministične vsebine, medtem ko je »film in feminizem « najbolj razvedrilen po svojem značaju, saj večinoma temelji na komentarjih o filmskih značajih in njihovem življenjskem stilu, pa tudi scenarističnih izbirah. Čeprav vsi prepoznani sklopi omenjajo in načenjajo vrsto podtem, razen $\mathrm{v}$ primeru feminističnega aktivizma, te podteme niso problematizirane, prav tako niso zastavljene tako, da bi jih občinstvo bolje razumelo. Mladi ljudje, kot redni porabniki novičarskih vsebin na najbolj obiskanih spletnih portalih, ne morejo pridobiti realistične podobe feminizma, le redko pa se, $v$ nekaj občasnih novicah, lahko izobrazijo o feminističnih vrednotah.

Ključne besede: feminizem, mediji, zvezdništvo, film, političarke, aktivizem 


\section{Mojca Šorli}

\section{FEMINISM AND GENDER-NEUTRAL LANGUAGE:}

\section{BETWEEN SYSTEMS AND EFFECTS}

The debate on language and gender in Slovenia raises the issue of gender-sensitive language use, which goes far beyond mere equality and inclusiveness in language use. While the establishment of (gender) identity in language is related to the theoretical question of the social construction of gender, ensuring gender equality in language is also a matter that requires social engagement in various fields, especially including various segments of the education system. As the first public debate on this issue - organised by the Faculty of Arts, University of Ljubljana, on 23 October 2018, following attempts to reduce gender inequality in legal documents adopted by the Faculty - showed, the approach to language and gender will necessarily be interdisciplinary. Linguistic considerations call for a shift in emphasis from vocabulary and address code (available resources) to arguments of morphosyntactic form and, in particular, to the symbolic structure of linguistic signs, taking into account relevant contributions from other research areas that have understood the attribution of gender - even sex - as a socially determined decision (e.g. Butler, 2001 /1990/, 1993). Since we are, at this point, particularly interested in the impact of gender-sensitive language use on the discursive level, we argue that the essence of the effort to make language more inclusive - with an emphasis on discourse in education - is not to offer, authorise and institutionalise individual solutions and strategies under the auspices of the language authorities, but to understand gender-sensitive language use as a multiplicity of micro-politics and as a continuous process that leads us to re-examine linguistic "facts" in relation to a given social context.

Key words: gender-sensitive language use, education, discourse, language system, masculinity as norm, grammatical gender, gender

\section{FEMINIZEM IN SPOLNA NEVTRALNOST V JEZIKU: SISTEMI IN UČINKI}

Razprava o jeziku in spolu v slovenskem prostoru načenja problematiko spolno občutljive rabe jezika (SORJ), ki daleč presega zgolj enakopravnost in inkluzivnost v jezikovni rabi. Vzpostavljanje (spolne) identitete v jeziku se navezuje tudi na teoretsko vprašanje družbene konstrukcije spola, obenem pa je zagotavljanje enakosti spolov v jeziku povsem operativno vprašanje, ki terja ukrepe na številnih poljih družbenega delovanja, tudi in še posebej v različnih segmentih izobraževanja. Kot je pokazala prva institucionalno organizirana javna razprava dne 23. oktobra 2018 na FF UL, ki je sledila sprejetju strategije za zmanjševanje nesorazmerij po spolu na 
Filozofski fakulteti Univerze v Ljubljani, bo pristop k vprašanjem jezika in spola nujno interdisciplinaren. $\mathrm{V}$ jezikoslovnih razmislekih je potreben preskok z osredinjenosti na leksiko in poimenovalnost (sredstva, ki že obstajajo) na argumente oblikoskladenjske ter zlasti simbolne moškosrediščne strukturiranosti jezikovnih znakov, pri čemer se ne bo mogoče povsem izogniti sodobnim spoznanjem družboslovnih ved in tudi delu naravoslovja (npr. Fausto-Sterling, 20I4) o tem, da je pripis spola družbena odločitev (npr. Butler, 200I /1990/, 1993). Na tem mestu, kjer nas zanimajo zlasti učinki SORJ na diskurzivni ravni, zagovarjamo stališče, da bistvo prizadevanj za bolj vključevalen jezik - s poudarkom na diskurzu v izobraževalnem okolju - ni v licitaciji, avtorizaciji in institucionalizaciji posameznih rešitev in strategij s strani jeziko(slo)vnih avtoritet, temveč v razumevanju SORJ kot množice mikropolitik in kontinuiranega procesa, $\mathrm{v}$ katerem nenehno preizprašujemo jezikovne samoumevnosti glede na dani družbeni kontekst.

Ključne besede: spolno občutljiva raba jezika, izobraževanje, diskurz, jezikovni sistem, moškost kot norma, slovnični spol, družbeni spol

\section{Majda Hrženjak}

\section{SPORTY BOYS AND FASHION GIRLS: MANOEUVRING} BETWEEN DOMINANT NORMS OF GENDER IDENTITY

The trigger for this article was the "Lévi-Straussian mythical formula" girls : boys $=$ fashion : football, which came to the fore in the conversation with girls and boys aged 13 and 14 years. Amid the cacophony of ambivalent representations and meanings of modern masculinities and femininities which young people are facing, it schematically expresses traditional symbolic relations and gender differences. International studies at the crossroads of cultural, educational and gender studies, including critical studies of men and masculinities (Frosh et al., 2002; Zaslow, 2009; Haywood \& Mac an Ghaill, 2007) show that teenagers use clothing practices to assert an imaginary boundary in relational and binary self-construction of masculine and feminine identity. The article analyses how teenagers deploy clothing practices, the strong attention they pay to their outfit and some other techniques of body self-regulation in order to negotiate social control and peer pressure related to the processes of the self-construction of masculine and feminine identity. The analysis looks at the peculiarities of these processes in doing hegemonic or marginalised masculinities and traditional or alternative femininities. Comparison of boys' and girls' (in intersections with classed and ethicised social locations) attitudes to clothing and outfit demonstrates that both experience the pressure of 
performing normative gender identity through their body, however the techniques of body self-regulation are different for boys and girls and for specific social locations. In the conclusion, the author reflects on the implications of teenagers' doing gender through body and their outfit for the pedagogical situation.

Key words: gender, masculinities, femininities, intersectionality, teenagers, body, feminist pedagogy

\section{ŠPORTNI FANTJE IN MODNA DEKLETA: MANEVRIRANJE} MED DOMINANTNIMI NORMAMI SPOLNE IDENTITETE

Izhodišče članka je »Lévi-Straussova mitska formula « dekleta : fantje = moda : nogomet, ki povzema pogovore $\mathrm{z}$ najstniki obeh spolov stari$\mathrm{mi} 13$ in $\mathrm{i} 4$ let. Kljub kakofoniji ambivalentnih reprezentacij in pomenov sodobnih moškosti in ženskosti, v katere vstopajo mladi, ta formula shematično izraža tradicionalna simbolna razmerja in spolne razlike. Mednarodne raziskave na presečišču kulturnih in pedagoških študij ter študij spola, vključno s kritičnimi študijami moških in moškosti (Frosh et al., 2002; Zaslow, 2009; Haywood \& Mac an Ghaill, 2007), izpostavljajo, da najstniki in najstnice uporabljajo oblačilne prakse za utrjevanje imaginarne meje $\mathrm{v}$ relacijski in binarni (samo)konstrukciji moške in ženske identitete. Članek analizira, kako najstniki in najstnice uporabljajo oblačilne prakse, oblikovanje svojega videza in nekatere druge tehnike telesne (samo)regulacije $\mathrm{v}$ procesih (samo)konstrukcije moškosti ali ženskosti ter $\mathrm{v}$ pogajanjih $\mathrm{z}$ vrstniškimi pritiski in družbenim nadzorom povezanim z uprizarjanjem spolne identitete (ang. doing gender). Analiza se osredotoča na posebnosti teh procesov v konstrukciji hegemonih oziroma marginaliziranih moškosti in tradicionalnih oziroma alternativnih ženskosti. Primerjava odnosa, ki ga imajo fantje in dekleta (v intersekcijah z razrednimi in etniziranimi družbenimi lokacijami) do oblačenja in videza, kaže, da oboji doživljajo pritisk, ki jih sili k uprizarjanju normativne spolne identitete skozi svoje telo, vendar so tehnike (samo)regulacije telesa drugačne pri fantih kot pri dekletih in na specifičnih družbenih lokacijah. V zaključku avtorica reflektira, kakšne implikacije ima lahko uprizarjanje spola pri najstnikih in najstnicah skozi telo in videz za pedagoško situacijo.

Ključne besede: spol, moškosti, ženskosti, intersekcionalnost, najstništvo, telo, feministična pedagogika 
THE GRAMMAR OF KNOWLEDGE:

\section{A LOOK AT FEMINISM AND FEMINIST EPISTEMOLOGIES}

The aim of the article is to reflect indirectly first on all the contributions in this volume, and second to help fix the present line of thought onto feminist epistemologies. Some postulates of feminist epistemologies are presented. The key question of feminist epistemology as a field of inquiry is defined according to Iris Van Der Tuin (2016) - it involves "the epistemic status of the knowledge produced by privileged and marginalized subjects", and the reflection about the intersection of knowledge and power. There are ethical and moral implications here: the challenge and responsibility to recognise power relations. If a knowing subject is understood as epistemically inferior, this has a negative effect on how they are understood in non-epistemic contexts (Fricker, 2017). Feminism, in other words, is an epistemological project (Bahovec, 2002).

Key words: feminist epistemology, feminism, alternative knowledge, power, knowing subject

\section{GRAMATIKA VEDNOSTI:}

\section{POGLED NA FEMINIZEM IN FEMINISTIČNE EPISTEMOLOGIJE}

Namen članka je, po eni strani, posredna refleksija o vseh prispevkih v tej številki revije; po drugi pa prizadevanje umestiti obstoječo miselno linijo v feministične epistemologije. Predstavljeni so nekateri postulati feminističnih epistemologij. Ključno vprašanje feministične epistemologije kot raziskovalnega področja je definirano po Iris Van Der Tuin (2016) - vključuje »epistemski status vednosti, ki jo proizvajajo privilegirani in marginalizirani subjekti« ter razmislek o medpresečnosti vednosti in oblasti. Tu nastajajo tudi etične in moralne implikacije: izziv in odgovornost prepoznati oblastna razmerja. Če je spoznavajoči subjekt prepoznan kot epistemsko manjvreden, ima to negativni učinek na to, kako je razumljen v ne-epistemskih kontekstih (Fricker 2017). Z drugimi besedami, feminizem je epistemološki projekt (Bahovec, 2002).

Ključne besede: feministična epistemologija, feminizem, alternativna vednost, oblast, spoznavajoči subjekt 


\section{Contributors • Avtorice}

\section{Mirjana Adamović}

Dr. sc. Mirjana Adamović, sociologist and senior scientific associate works at the Institute for Social Research in Zagreb. She is also an external associate for postgraduate doctoral studies in Humanities at the University of Split. She is the co-author of three books and editor of another one and the author of numerous scientific papers related to gender, feminism and culture. Her research and policy expertise has been developed through collaboration with many national and international organisations.

Dr. Mirjana Adamović je sociologinja in višja znanstvena sodelavka na Inštitutu za družbena raziskovanja v Zagrebu. Je tudi zunanja sodelavka podiplomskih doktorskih študij v humanistiki na Univerzi v Splitu. Je soavtorica treh knjig in urednica enega dela ter avtorica številnih znanstvenih člankov s področja spola, feminizma in kulture. Njeno raziskovanje in poznavanje politik se razvijata $\mathrm{v}$ sodelovanju s številnimi nacionalnimi in mednarodnimi organizacijami.

\section{Majda Hrženjak}

Dr Majda Hrženjak, sociologist, is acting as a senior research associate at the Peace Institute - Institute for Contemporary Social and Political Studies in Slovenia. Her research topics are gender studies and social politics, with a focus on the concept of care in relation to intersectional inequalities, citizenship, migration and feminist ethics of care. Her bibliography includes the monographs Symbolic (200I); Invisible Work (2007) and Dimensions of Care Work (2018). She edited the books Making Her Up: Women's Magazines in Slovenia (2002); Politics of Care (2011) and Changing 
Fatherhood: Men between Work and Parenthood (2016). Among others, she was a guest editor of the thematic issue First Gender: Critical Studies of Men and Masculinities of the Journal for the Critique of Science (2017).

Majda Hrženjak, doktorica sociologije, deluje kot višja znanstvena sodelavka na Mirovnem inštitutu. Raziskovalno se osredotoča na študije spolov in socialne politike, zlasti na koncept skrbi v povezavi z intersekcijskimi neenakostmi, državljanstvom, migracijami in feministično etiko skrbi. Je avtorica monografij Simbolno (200I), Nevidno delo (2007), Razsežnosti skrbstvenega dela (2018) in urednica zbornikov Njena (re)kreacija: Ženske revije $v$ Sloveniji (2002), Politics of Care (2011), Spremembe očetovstva: moški med delom in starševstvom (2016). Med drugim je kot gostujoča urednica Časopisa za kritiko znanosti uredila tematsko številko Prvi spol: kritične studije moških in moškosti (2017).

\section{Biljana Kašić}

Professor (ret.) Biljana Kašić from the Department of Sociology, University of Zadar is a co-founder and long-term associate of the Women's Studies Centre in Zagreb. She has taught at various universities across Croatia and internationally. She is the author and co-author of several books, studies and papers published in Croatia and abroad related to feminist epistemology, post-colonial theories, women's culture of resistance and theories of identities.

Biljana Kašić je upokojena profesorica Univerze v Zadru, Oddelek za sociologijo, soustanoviteljica in dolgoletna sodelavka Centra za ženske študije v Zagrebu. Bila je predavateljica na številnih univerzah na Hrvaškem in v mednarodnem prostoru. Je avtorica in soavtorica številnih knjig, študij in člankov, ki so izšli na Hrvaškem in v tujini in ki se ukvarjajo $s$ feministično epistemologijo, postkolonialnimi teorijami, žensko kulturo odpora in teorijami identitet.

\section{Ana Mladenović}

Ana Mladenović completed her masters in Sociology with a focus on Gender and Sexuality Studies in April 2015. Since October 2015, she has been an early-stage researcher at the Educational Research Institute in Ljubljana, Slovenia, where she is writing her PhD dissertation in the field of education and feminist theory.

Ana Mladenović je v aprilu 2015 zaključila magistrski študij sociologije, v sklopu katerega je vpisala modul Študiji spola in spolnosti. Od oktobra 2015 je zaposlena kot mlada raziskovalka na Pedagoškem inštitutu v Ljubljani, kjer zaključuje doktorsko disertacijo s področja edukacijskih ved in feministične teorije. 


\section{Metka Mencin}

Dr Metka Mencin is an assistant professor of Social Psychology, and a lecturer and researcher at the Faculty of Social Sciences, University of Ljubljana. Her main research interests are the construction of stigmatised identities and (re)production of power relations within sciences (psychology), education, state policies and everyday discourse. She is the co-author of several monographs and the author/co-author of several scientific, expert and popular articles.

Dr. Metka Mencin je docentka socialne psihologije, predavateljica in raziskovalka na Fakulteti za družbene vede Univerze v Ljubljani. Njeni glavi raziskovalni interesi so konstrukcija stigmatiziranih identitet in (re)produkcija oblastnih razmerij v znanostih (psihologiji), izobraževanju, državnih politikah in vsakdanjem diskurzu. Je soavtorica več monografij ter avtorica in soavtorica številnih znanstvenih, strokovnih in poljudnih člankov.

\section{Nina Perger}

Dr Nina Perger is a researcher at the Faculty of Social Sciences, University of Ljubljana. Her research areas include everyday life studies, focusing on gender, sexuality and non-binary identities, masculine domination and sexism. She is the author and co-author of several scientific articles. Dr. Nina Perger je raziskovalka na Fakulteti za družbene vede na Univerzi v Ljubljani. Njena raziskovalna področja so študije vsakdanjega življenja, s poudarkom na spolu, seksualnosti in nebinarnih identitetah, moški dominaciji in seksizmu.

\section{Renata Šribar}

Dr Renata Šribar is an associate professor of Anthropology, implementing feminist and critical pedagogy in lecturing. As a researcher, she focuses on genders and transgender studies, ethics in science, health, and transformative research methodology. Lately, she has been problematising the new technological turn (scientifically questionable implementation of $5 \mathrm{G}$, sexism in the commercial introduction of sex robots ...). She has (co)authored four scientific monographs and several articles and book chapters related to gendering, (porno)sexualisation, digitalisation, and science. In addition to the exposed primary work sphere, she deals with active citizenship, literature, and complementary healing.

Dr. Renata Šribar je izredna profesorica za antropologijo, ki v svojo predavateljsko prakso uvaja feministično in kritično pedagogiko. Kot raziskovalka se osredotoča na študije spolov in transspolov, etiko $\mathrm{v}$ znanosti, zdravje in metodologijo transformativnega raziskovanja. V aktualnem 
obdobju problematizira nov tehnološki obrat (znanstveno vprašljivo uvajanje tehnologije $5 \mathrm{G}$, seksizem industrije seks robotov ...). Je avtorica štirih znanstvenih monografij in več člankov in knjižnih poglavij, povezanih $s$ spolom, (porno)seksualizacijo, digitalizacijo in feministično in etično refleksijo znanosti. Poleg izpostavljene primarne delovne sfere jo zanimajo aktivno državljanstvo, literatura in komplementarno zdravljenje.

\section{Mojca Šorli}

Mojca Šorli, PhD, is a linguist, publicist and translator. The central areas of her research are corpus linguistics, corpus pragmatics, discourse analysis, translation studies and contrastive language analysis. She is affiliated with the Faculty of Arts, University of Ljubljana, and the Institute for Slovenian Literature and Literary Studies ZRC SAZU. She engages publicly in general linguistic and other current social debates, especially those related to the position of women and the representation of gender in public discourse. She is a member and former volunteer of the Slovenian SOS Helpline Society.

Mojca Šorli je doktorica jezikoslovnih znanosti, raziskovalka, publicistka in prevajalka. Osrednja področja njenega raziskovanja so korpusno jezikoslovje, korpusna pragmatika, analiza diskurza, prevodoslovje in kontrastivna analiza jezikov. Zaposlena je na Filozofski fakulteti UL in Inštitutu za slovensko literaturo in literarne vede ZRC SAZU. Objavlja tudi besedila o splošnih jezikovnih ter drugih aktualnih družbenih temah, zlasti v povezavi s položajem žensk in reprezentacijo družbenih spolov v javnem diskurzu. Je članica in nekdanja prostovoljka Društva SOS telefon.

\section{Veronika Tašner}

Dr Veronika Tašner is an assistant professor of Sociology of Education at the Faculty of Education, University of Ljubljana. Her research areas are meritocracy, equity and inequality in education, gender and education, comparative education, violence and school, future of education and private/public education. She has edited and co-edited several monographs, including: Brez spopada: kultur, spolov, generacij (Without conflict between civilizations, genders, generations), Prihodnost šole $v$ družbah dela brez dela (Future of school in work-centred societies without work), Zasebno šolstvo $v$ Sloveniji (Private schools in Slovenia), Misliti socialne inovacije (Thinking social innovation).

Dr. Veronika Tašner je docentka za sociologijo vzgoje na Pedagoški fakulteti Univerze v Ljubljani. Njena raziskovalna področja so meritokracija, pravičnost in neenakost v edukaciji, spol in edukacija, primerjava sistemov edukacije, nasilje in šola, prihodnost edukacije in javno/zasebno šolstvo. 
Uredila in souredila je več monografij, med njimi Brez spopada: kultur, spolov, generacij, Prihodnost šole v družbah dela brez dela, Zasebno šolstvo $v$ Sloveniji, Misliti socialne inovacije.

\section{Valerija Vendramin}

Valerija Vendramin, $\mathrm{PhD}$ in Women's Studies, is a researcher at the Educational Research Institute in Ljubljana. Her current fields of interest encompass educational studies, women's studies and feminist theory, (chiefly, but not exclusively, in connection to issues concerning the conceptualisation of sexual difference, curriculum and feminist critiques of science together with epistemological issues). She is the author of various articles on these issues and the translator of a number of relevant theoretical works.

Valerija Vendramin je doktorica ženskih študij, zaposlena pa je kot raziskovalka na Pedagoškem inštitutu v Ljubljani. Med njenimi interesnimi področji so edukacijske študije, ženske študije in feministična teorija (v tem okviru se ukvarja s problematiko, ki zadeva konceptualizacijo spolne razlike, kurikulum in feministične kritike znanosti oz. epistemološka vprašanja). Je avtorica številnih znanstvenih člankov in* prevodov $s$ teh področij. 


\section{Navodila za avtorje in avtorice}

Kontrolni seznam za oddajo prispevka

V postopku oddaje se od avtorjev in avtoric zahteva, da potrdijo skladnost prispevka s spodaj navedenimi točkami, prispevek pa se lahko zavrne, če ne ustreza navedenim usmeritvam:

- Prispevek predstavlja izvirno avtorsko delo. Prispevek še ni bil objavljen, prav tako v danem trenutku ni v procesu recenziranja za objavo v drugi reviji oziroma publikaciji.

- Prispevek je skladen z namenom revije.

- Prispevek vključuje vse zahtevane elemente, opredeljene v Navodilih za avtorje in avtorice, ki so objavljena na spletni strani revije.

- Prispevek upošteva slogovne in bibliografske zahteve, opredeljene v Navodilih za avtorje in avtorice, ki so objavljena na spletni strani revije.

\section{Splošna navodila}

Prispevek oddan v revijo Šolsko polje, vključuje:

- Spremno pismo, v katerem avtor oziroma avtorica uredništvu predstavi skladnost prispevka z namenom revije, vključno z opredelitvijo, kako prispevek dopolnjuje in nadgrajuje že objavljena dela na določenem znanstvenem/strokovnem področju. V spremnem pismu avtor oziroma avtorica predlaga kategorijo prispevka (izvirni znanstveni članek, pregledni znanstveni članek, kratek znanstveni prispevek, strokovni članek).

- Naslovna stran, v kateri avtor oziroma avtorica navede naslov prispevka, ime in priimek avtorja oziroma avtorice, akademski naziv, organizacijo, kjer je avtor oziroma avtorica zaposlen, elektronski naslov ter kratko predstavitev avtorja oziroma avtorice v slovenskem in angleškem jeziku (od 70-ıoo besed). Naslovna stran je namenjena zagotavljanju anonimnosti recenzentskega postopka in predstavitvi podatkov, ki ne smejo biti vključeni v datoteko $\mathrm{z}$ besedilom prispevka.

- Prispevek (praviloma v obsegu od 5.000 do 7.000 besed) naj vključuje:

I) Naslov v slovenskem in angleškem jeziku (do 20 besed),

2) Povzetek v slovenskem in angleškem jeziku (od 200 do 250 besed),

3) Ključne besede v slovenskem in angleškem jeziku (od 3 do 5 besed),

4) Besedilo prispevka,

5) Seznam uporabljene literature,

6) Morebitne zahvale in navedbo virov financiranja raziskave.

Zaradi zagotavljanja anonimnosti recenzentskega postopka bodite ob oddaji datoteke z besedilom prispevka pozorni na to, da v njej ni navedenih avtorjevih oziroma avtoričinih osebnih podatkov. Zagotovite, da iz lastnosti dokumenta ni mogoče prepoznati avtorja oziroma avtorice prispevka.

- Morebitne priloge (likovno gradivo in druge priloge).

Jezikovna ustreznost prispevka

Prispevek naj bo napisan v knjižni slovenščini ob upoštevanju veljavnega pravopisa, oziroma v britanski angleščini, $\mathrm{v}$ nasprotnem primeru si uredništvo pridržuje pravico, da prispevka ne recenzira, oziroma ga zavrne.

Oblikovanje prispevka, likovna oprema in navajanje virov

Oblikovanje prispevka, likovna oprema in navajanje virov naj sledi pravilom Ameriškega psihološkega združenja (APA).

Podrobnejša navodila so dostopna na tej povezavi: https://apastyle.apa.org/

$\mathrm{O}$ morebitnih drugih posebnostih se posvetujte $\mathrm{z}$ uredništvom.

Oddaja prispevka

Prispevke pošljite po elektronski pošti na naslov uredništva: solsko.polje@guest.arnes.si. 


\section{Instructions for authors}

\section{Checklist for article submission}

All articles should comply with the requirements listed below. A lack of compliance may result in the article's being rejected.

- The article should be the author's or authors' own, original work. It should not have been previously published, nor should it be under consideration for publication elsewhere.

- The article should match the aims and scope of the journal.

- The article should be submitted along with all the details set out in the Instructions for Authors. These can be found on the website.

- The article should comply with the stylistic and bibliographical requirements set out in the Instructions for Authors. These can be found on the website.

\section{General instructions}

When submitting an article to Šolsko polje, authors should include the following:

- A cover letter confirming the article's relevance to the journal's subject area and describing how it adds to and/or enhances the existing scientific literature on the topic. Authors should also specify a category for their submission (original scientific article, scientific review article, short scientific article, expert article).

- A cover page giving the title of the article along with the author's name, academic title, institutional affiliation, email address, and a brief academic resumé ( $70-100$ words) in both Slovenian and English. The purpose of the cover page is to provide details that are not permitted in the manuscript itself, thereby ensuring the anonymity of the review procedure.

- The manuscript (normally 5000 to 7000 words) including:

I) The title in Slovenian and English (20 words max)

2) An abstract in Slovenian and English (200 to 250 words)

3) Key words in Slovenian and English ( 3 to 5 words)

4) The text of the article

5) A references list

6) Acknowledgement of any funding support received for your research.

In order to ensure the anonymity of the review procedure, you must not include any personal data in the manuscript file. You must also ensure that you cannot be identified from any of the file properties.

- Supplementary material if applicable (e.g. tables, diagrams, photographs, etc.)

Linguistic requirements

The paper should be written in either standard Slovenian or British English and be grammatically correct. The editorial board reserves the right to refuse to review or publish any article that does not meet this requirement.

Manuscript format, Graphics and References

Manuscript format, Graphics and References should be in APA format, in accordance with the rules of the American Psychological Association.

For more detailed instructions see https://apastyle.apa.org/

For any other referencing queries, please contact the editor.

Article submission

All articles should be emailed to the editorial board: solsko.polje@guest.arnes.si. 


\section{Šolsko polje}

Revija za teorijo in raziskave vzgoje in izobraževanja

Letnik XXXI, številka 5-6, 2020

\section{Valerija Vendramin}

5 Teaching and Trending Feminism in the $2 \mathrm{I}^{\mathrm{st}}$ Century

Editorial

\section{Nina Perger, Metka Mencin and Veronika Tašner}

I3 Teaching Feminism:Between Marginalisation and Feminist Persistence

\section{Biljana Kašić}

3I Feminism as Epistemic Disobedience and Transformative Knowledge:

Exploration of an Alternative Educational Centre

\section{Renata Šribar}

49 Study in the Virtual Class: Doings of Feminist Pedagogy and the Covid-19 Crisis

\section{Ana Mladenović}

67 Feminist Classrooms in Practice

\section{Mirjana Adamović}

83 What Can We Learn About Feminism from Web Portals?

- Analysing Media Bulletins

\section{Mojca Šorli}

I03 Feminism and Gender-Neutral Language: Between Systems and Effects

\section{Majda Hrženjak}

I2I Sporty Boys and Fashion Girls: Manoeuvring Between Dominant Norms of Gender Identity

\section{Valerija Vendramin}

I39 The Grammar of Knowledge:A Look at Feminism and Feminist Epistemologies 